The University of Maine

DigitalCommons@UMaine

Health \& Public Safety

Margaret Chase Smith Policy Center

2016

\title{
The Cost of Alcohol and Drug Abuse in Maine, 2015
}

Marcella H. Sorg

University of Maine, mhsorg@maine.edu

Jamie A. Wren

University of Maine, jamie.a.wren@maine.edu

Follow this and additional works at: https://digitalcommons.library.umaine.edu/

mcspc_healthsafety

Part of the Other Chemicals and Drugs Commons, Substance Abuse and Addiction Commons, and the Toxicology Commons

\section{Repository Citation}

Sorg, Marcella H. and Wren, Jamie A., "The Cost of Alcohol and Drug Abuse in Maine, 2015" (2016). Health \& Public Safety. 1. https://digitalcommons.library.umaine.edu/mcspc_healthsafety/1

This Article is brought to you for free and open access by DigitalCommons@UMaine. It has been accepted for inclusion in Health \& Public Safety by an authorized administrator of DigitalCommons@UMaine. For more information, please contact um.library.technical.services@maine.edu. 


\section{The Cost of}

\section{Alcohol and Drug Abuse}

in

Maine, 2010

April 2013

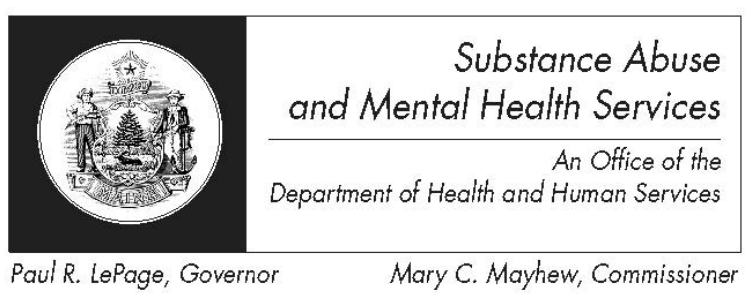



Prepared for: Office of Substance Abuse and Mental Health Services

Department of Health and Human Services

Anne L. Rogers, Maine Office of Substance Abuse and Mental Health Services Marcella H. Sorg, Margaret Chase Smith Policy Center, University of Maine

Jamie A. Wren, Margaret Chase Smith Policy Center, University of Maine

For more information, contact:

Maine Office of Substance Abuse and Mental Health Services

Information \& Resource Center

\#11 State House Station

Augusta, ME 04333-0011

Web: http://www.maine.gov/dhhs/samhs/osa/

Email: osa.ircosa@maine.gov

1-800-499-0027 or (207)287-8900

TTY: 711 (Maine Relay) 


\section{TABLE OF CONTENTS}

List of Tables

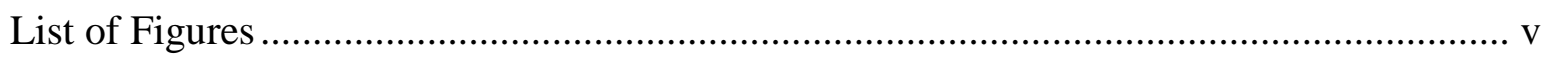

Executive Summary .......................................................................................... 1

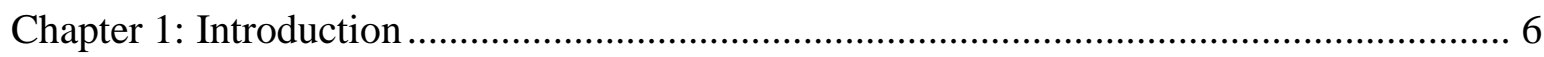

Introduction and Background ............................................................ 6

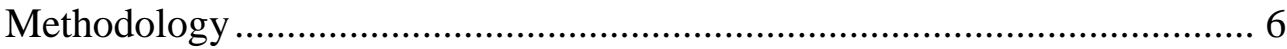

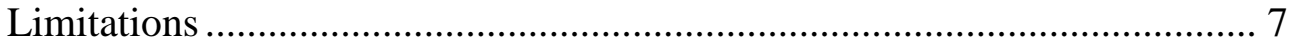

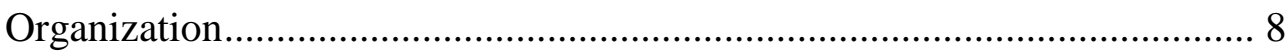

Chapter 2: Substance Abuse Treatment ........................................................................ 9

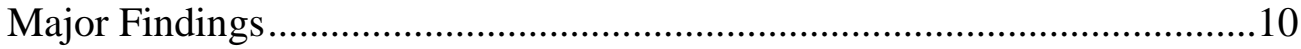

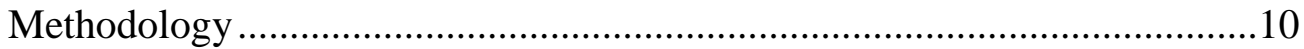

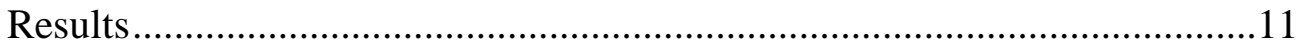

Summary and Implications ...........................................................14

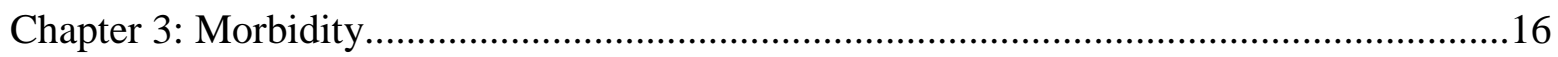

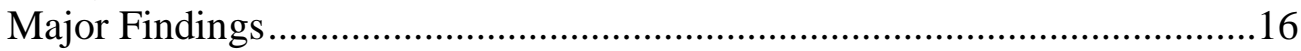

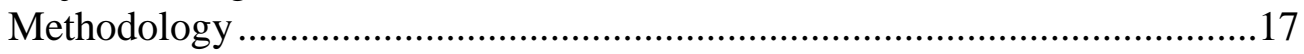

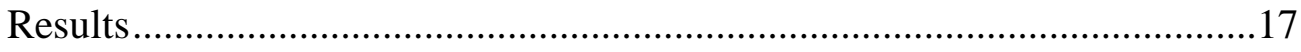

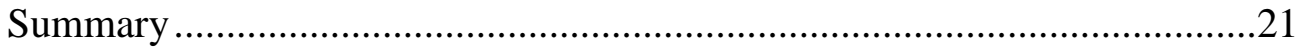

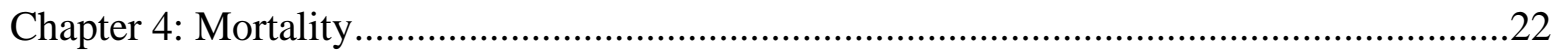

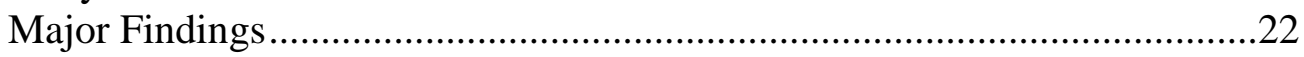

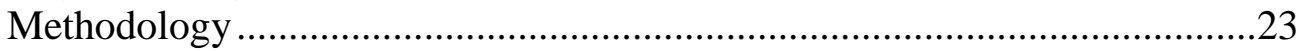

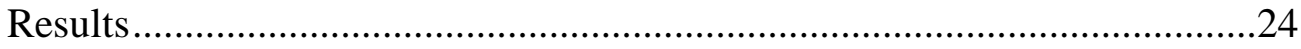

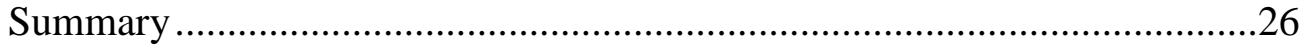

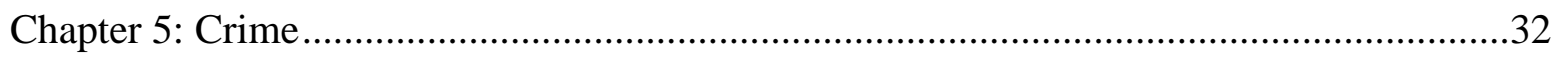

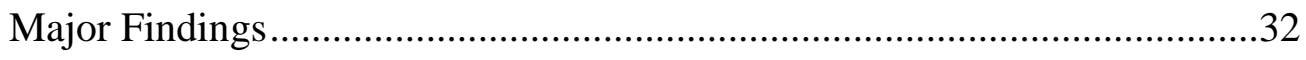

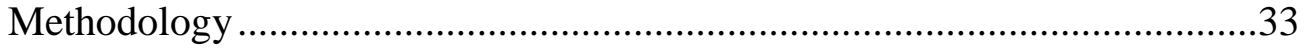

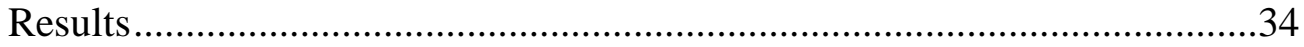

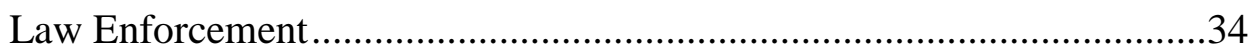

Police Protection .............................................................................34

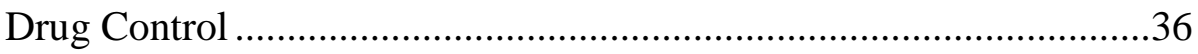

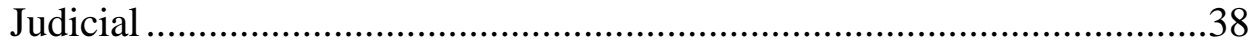

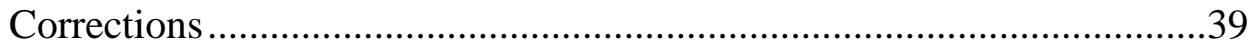

State Corrections .................................................................40

County Corrections ................................................................. 41

Other Societal Costs...............................................................................43

Productivity Losses Due to Incarceration ........................................44 
Property Destruction ..................................................................44

Criminal Victimization .............................................................46

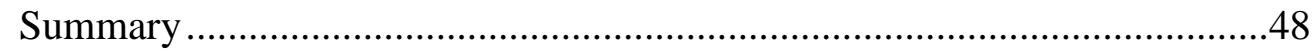

Chapter 6: Medical Care .............................................................................................50

Major Findings ...............................................................................5

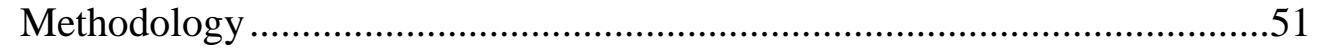

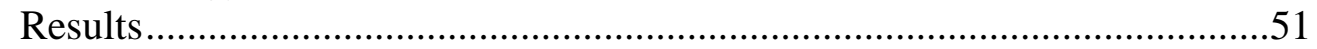

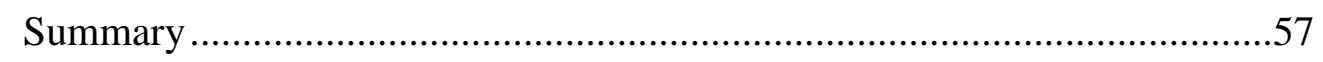

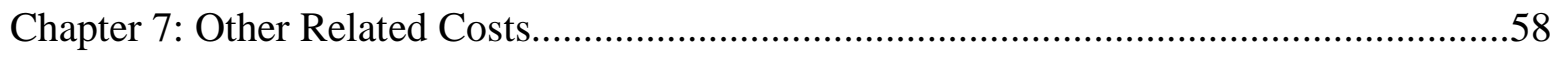

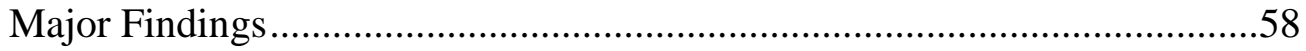

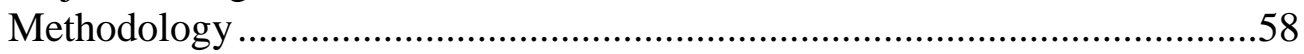

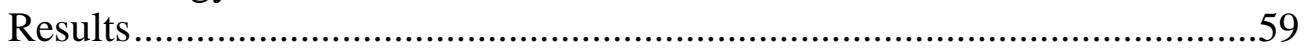

Child Welfare ................................................................................59

Social Welfare Administration ......................................................59

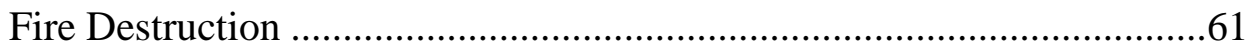

Motor Vehicle Crashes (Non-Medical) .............................................62

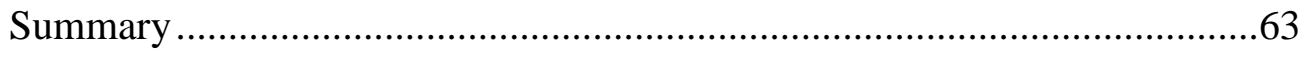

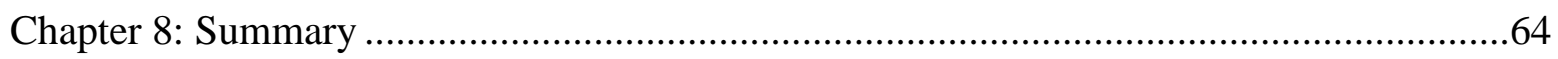

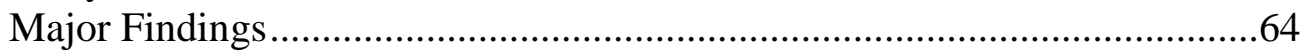

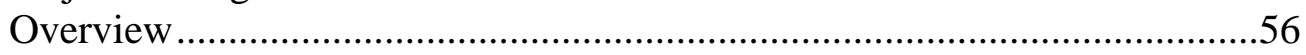

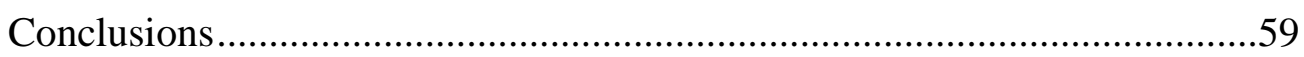

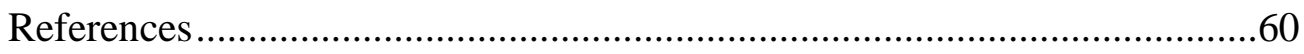

Appendices

A. Calculation of Estimated Morbidity Costs, 2010

B.1 ICD-9 Codes and Alcohol Attributable Fractions for Alcohol-Related Injuries and Associated Hospital Inpatient Charges, Maine, 2010

B.2 ICD-9 Codes and Alcohol Attributable Fractions for Alcohol-Related Injuries and Associated Hospital Outpatient Charges, Maine, 2010

C. Estimated Costs of Alcohol Related Motor Vehicle Crashes, Maine, 2010

D. Data Sources for this Report 


\section{LIST OF TABLES \& FIGURES}

Table

Page

$2.1 \quad$ Treatment funding by payer, Maine, 2010 ......................................................11

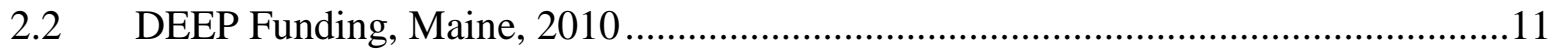

2.3 Number of admissions for treatment by type of disorder, Maine, 2010 ..................12

2.4 Number of clients receiving treatment by type of disorder, Maine, 2010 ................12

2.5 Admissions for treatment by race, Maine, 2010 ..................................................13

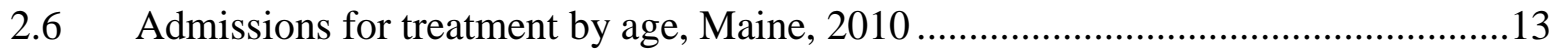

3.1 Estimated number of adults with abuse or dependence, by gender and age,

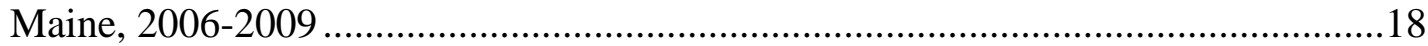

3.2 Estimated number of adults with abuse or dependence, by gender, age, and employment

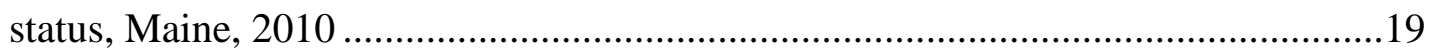

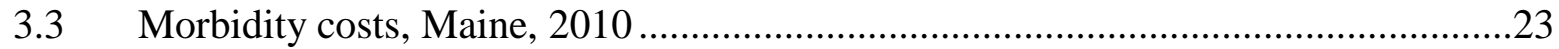

4.1 Number of alcohol- and drug-related deaths by age and gender, Maine, 2010 ........24

4.2 Deaths attributable to alcohol by diagnosis and gender, Maine, 2010 ....................27

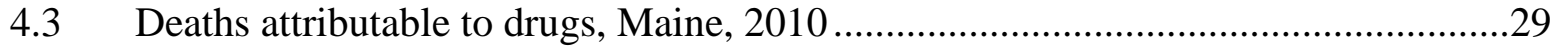

4.4 Estimated mortality costs and years of potential life lost, Maine, 2010 ..................30

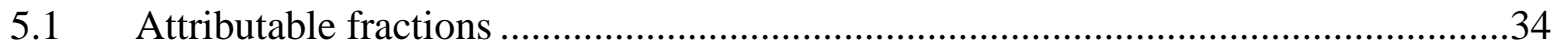

$5.2 \quad$ Estimated cost of police protection, Maine, 2010 ..............................................35

5.3 Drug Control Expenditures, Maine, 2010 ..........................................................36

$5.4 \quad$ Substance Control Expenditures, Maine, 2010 ...................................................37

$5.5 \quad$ Legal and adjudication costs, Maine, 2010 .....................................................38

5.6 Estimated cost of state corrections, Maine, 2010 ................................................40

5.7 Estimated cost of county corrections, Maine, 2010 ...........................................42

5.8 Estimated productivity losses due to incarceration, Maine, 2010 ..........................45

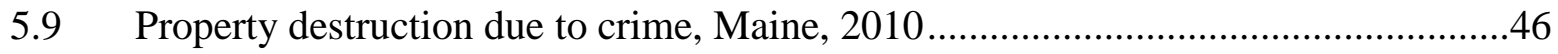

5.10 Estimated productivity losses for victims of crime, Maine, 2010 ..........................47

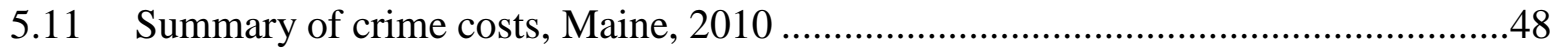

6.1a Estimated alcohol-related hospital inpatient direct costs, Maine, 2010...................53 
List of Tables \& Figures (continued)

6.1b Estimated drug-related hospital inpatient direct costs, Maine, 2010 .......................54

6.2a Estimated alcohol-related hospital outpatient charges, Maine, 2010 .......................55

6.2b Estimated drug-related hospital outpatient charges, Maine, 2010............................56

6.2c Total estimated hospital inpatient/outpatient charges, Maine, 2010.......................57

6.3 Other medical costs due to alcohol, Maine, 2010 .................................................58

7.1 Estimated administrative costs of selected social welfare programs attributed

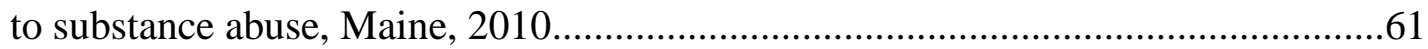

7.2 Estimated alcohol-related cost of fire protection and property damage and destruction due to fire, Maine, 2010

7.3 Estimated non-medical cost of alcohol-related motor vehicle crashes, Maine, 2010 .64

8.1 Summary: Estimated cost of alcohol and drug abuse by category, Maine, 2010 ......66

2.12010 Public Funds Spent on Treatment ..............................................................14

$2.2 \quad 2010$ Private Funds Spent on Treatment ..............................................................15

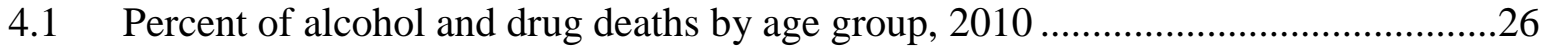

8.1 Comparison of costs, 2000, 2005, \& 2010......................................................67

8.2 Distribution of substance abuse costs, Maine, 2010 ............................................68 


\section{The Cost of Alcohol and Drug Abuse in Maine: 2010 Executive Summary}

Published by the Maine Office of Substance Abuse and Mental Health Services, April 2013

\section{Summary findings}

- In 2010, the total estimated cost of substance abuse in Maine was \$1.403 billion.

- This $\$ 1.403$ billion translates into a cost equaling \$1,057 for every resident of Maine.

- $\quad$ This was a 56.2\% increase from 2005.

- Substance abuse treatment (\$47.0 million) comprised the smallest proportion of total cost (3.4\%), while mortality, \$409.6 million, comprised the largest proportion of costs (24.8\%).

\section{Substance abuse treatment}

Treatment services available in Maine to help persons with substance use disorders include various levels of residential programs, outpatient programs, medication assisted treatment, detoxification, and specialty programs for youth, pregnant women, and persons who are diagnosed with both mental health and substance use disorders.

\section{Summary findings:}

- The total estimated cost of providing treatment and intervention in Maine in 2010, based on reported annual revenue in the Treatment Data System (TDS), was \$47.0 million, \$45.6 million of which was spent on admissions for treatment, shelter, and detoxification.

- Of the $\$ 45.6$ million; $79 \%$ is from public funds (state and federal) $21 \%$ from private funding sources. Of public funds, $53 \%$ is from Federal Medicaid and $16 \%$ is from other Federal grants. Of private funds, $74 \%$ is from client payments and $26 \%$ is from private insurance. 
- An additional \$1.4 million was spent on Driver Education and Evaluation Program (DEEP), which was covered fully by client payments.

- Approximately 16,818 admissions for drug and/or alcohol related treatment was reported during 2010, representing 14,996 distinct individuals.

- It is estimated that more than $10 \%$ of $18-24$ year olds in Maine meet the criteria for drug abuse or dependence.

\section{Morbidity}

Alcohol and drug abuse or dependence may adversely affect an individual's work productivity as well as his or her ability to function in other roles. Examples of reduced work productivity would include a worker calling in sick or working while hung-over from heavy drinking the night before, using drugs or alcohol on the job, or leaving work early to use drugs and consume alcohol. An individual's productivity in other non-work roles may also be affected by alcohol or drug use, e.g. performing household or child-care duties. In all these cases, reduced output resulting from alcohol or drug use can be measured as an economic loss. It is often assumed, incorrectly, that the affected worker or individual incurs all of the costs for his or her behavior. However, productivity loss due to alcohol and drug abuse or dependence creates an economic loss borne by society at large.

Summary findings:

- Total estimated morbidity costs in 2010 due to alcohol or drug abuse was \$188.6 million.

- Males accounted for $66.9 \%$ of total costs.

- Males aged 45-64 accounted for the largest portion of alcohol morbidity costs.

\section{Mortality}

A major economic loss is imposed on society by premature death from substance use and abuse. Premature death through illness or injury can occur through auto and other accidents 
involving alcohol, through liver diseases such as hepatitis and cirrhosis, through increasing the risk of cancer or cerebrovascular disease, and through violence involving drugs or alcohol. When an individual dies prematurely, there is an economic cost to society in the form of the loss of that individual's productive capacity.

Summary findings:

- 713 deaths related to drug and alcohol abuse occurred in 2010, (538 alcohol-related and 175 drug-related deaths), resulting in 15,896 years of potential life lost.

- Major causes of death were:

a. cancer (various types) - 132 deaths

b. accidental drug poisoning -128 deaths

c. cirrhosis and liver damage -102 deaths

d. motor vehicle accidents -66 deaths

e. drug-induced suicide - 52 deaths

- Total mortality costs for 2010 were $\$ 409.6$ million. Of this amount, $\$ 240.9$ million resulted from alcohol abuse and \$168.7 million from drug abuse.

- The average cost per death in 2010 , measured in lost earnings, was $\$ 574,534$.

\section{Crime}

Recent surveys of incarcerated populations provide evidence of the strong link between crime and substance abuse. In 2004, one in four federal inmates (26\%) and one in three state inmates (32\%) reported that they were under the influence of alcohol or illicit drugs at the time of their current offense. Fifty-three percent (53\%) of State and 45\% of Federal prisoners met the diagnostic criteria for drug dependence or abuse (US Department of Justice, 2006).

\section{Summary findings:}

- Of 19 arrests for homicide in 2010, an estimated 6 were related to alcohol and 3 to drug abuse. 
- In 2010 there were 7,083 assault (aggravated, sexual and other) related arrests, of which an estimated 2,120 were related to alcohol abuse and 345 to drug abuse.

- Total estimated drug- and alcohol-related crime costs in 2010 were \$343.4 million.

- Of the four major crime cost categories analyzed, law enforcement costs were highest (\$119.7 million), followed by the cost of corrections (\$111.0 million).

\section{Medical care}

Alcohol and drug abuse increases the risk of illness or injury and thereby increases the use of health care services. The effects of substance abuse on health care utilization may be obvious and immediate or more indirect and long term. The link between substance use and health care costs is clear in the case of an individual overdosing on drugs and then requiring hospitalization, or a person who is injured in an alcohol or drug involved auto accident or other accident and requires emergency hospital treatment. But prolonged alcohol and drug abuse can also increase the risk for a number of diseases, including stomach cancer, cancer of the esophagus, respiratory tuberculosis, stroke, liver damage and pancreatitis, thereby increasing the demand for costly medical care as well as premature nursing home care.

\section{Summary findings:}

- There were approximately 8,302 hospital discharges in Maine in 2010 directly or indirectly related to drug and alcohol use or abuse.

- The total cost of providing hospital inpatient care for these patients, including adjustment for longer stays due to co-occurring substance dependency, was estimated at $\$ 145.1$ million, $83.4 \%$ of which was related to alcohol use.

- The estimated cost of 2010 outpatient medical care was $\$ 122.6$ million; $74.7 \%$ of those costs were attributable to alcohol use.

- Prescription drug costs and nursing home costs attributable to alcohol were, respectively, \$27.7 million and \$7.5 million.

- $\quad$ The total estimated medical cost in 2010 was $\$ 302.8$ million. 


\section{Other related costs}

Substance use and abuse impacts a number of areas not included in the previous sections: These include child welfare and the administration of other social welfare programs, fire protection and the destruction caused by fire, and the non-medical costs of motor vehicle accidents.

\section{Summary findings:}

- An estimated \$45.9 million in child welfare costs related to substance abuse was spent in Maine during 2010.

- An estimated \$3.5 million was spent on the administration of other social welfare programs related to drug and alcohol abuse in Maine during 2010.

- Alcohol is plays a role in many fires. In 2010, the estimated cost of these alcohol related fires in Maine was $\$ 9.5$ million.

- The cost of alcohol-related motor vehicle crashes in Maine in 2010 is estimated at \$53.1 million.

- The combined cost of all three cost categories was $\$ 111.9$ million 


\section{Chapter 1 \\ Introduction}

\section{Introduction and Background}

This report uses nationally accepted practices in an attempt to quantify, in monetary terms, the consequences of alcohol and drug abuse for the State of Maine. The problem of alcohol and drug abuse continues to be a major social concern, with serious personal, social and economic consequences. Alcohol and drug abuse cause illness, disability and premature death. The burden on society includes the use of costly health care resources, significant productivity (economic) losses due to morbidity, serious injuries from accidents, and criminal activity resulting in property damage and incarceration. Earlier reports sponsored by the Office of Substance Abuse estimated the cost of substance abuse as $\$ 485$ per Maine citizen in 2000, and \$682 per Maine citizen in 2005. The current report provides an update using 2010 data; it estimates a total of $\$ 1,040$ costs per person.

\section{Methodology}

This study used the following to estimate costs: 1) review of the literature on updated substance related cost estimates (in particular, proportions and attributable fractions); and 2) review of the 2005 study to align as close as possible to prior methodology to allow comparison. In general this study follows "Cost of Illness" guidelines focusing on tangible costs. Prevalencebased cost estimation studies measure how many cases there are of a disorder or consequence over a period of time, the costs or value of the resources used to treat the disorder, and the lost productivity during a specified period of time. For the current study, the base period is calendar year 2010. The population of interest resides in the State of Maine, estimated as 1,328,361 persons in 2010 (US Census Bureau, 2010).

Cost of illness studies require a monetary value to be placed on human life. This study uses the same approach in determining a life value as was done in the 2005 report: the human capital approach, which measures an individual's value to society in terms of his or her production potential, reflected in earnings. Using this perspective, the value of an individual to 
society is his or her earnings, and the value of a life lost due to premature death is calculated as the missed future earnings of that individual.

Studies using the human capital approach measure both the direct and indirect costs of specific disease categories. Direct costs are those for which payments are made (e.g., medical care or alcohol treatment); indirect costs are those for which resources are lost (e.g., lost productivity due to morbidity or mortality). Using this approach the estimation of direct costs is straightforward; but indirect costs are more difficult to analyze because they require a value based upon a person's earnings and production potential. This may undervalue certain members of society: children, elderly, people with disabilities, ethnic minorities and women. Despite its limitations, the human capital approach remains widely used and provides a useful method for analyzing the cost of disease.

\section{Limitations}

This analysis has several limitations that merit mention. First, any cost estimation study may miss certain costs. It's important to remember that this report provides a conservative estimate of the costs of substance abuse to Maine, but does not capture all of the associated economic costs.

Second, to estimate costs related to drug and alcohol abuse, the analyses often had to assign a portion of total costs to substance abuse. Prior studies have developed these “attributable fractions" based upon research and surveys conducted that can be used to estimate the portion of total costs that can reasonably be attributed to alcohol or drug use (US DOJ/NDIC, 2011; The Lewin Group, 2010; NIDA/NIAAA, 1998). For example, if research shows that alcohol abuse contributes to approximately $30 \%$ of all stomach cancers, then only $30 \%$ of medical costs incurred in treating stomach cancer should be attributable to alcohol abuse. The attributable fractions used here are the same as those used for a national cost analysis (US DOJ/NDIC, 2011; The Lewin Group, 2010; NIDA/NIAAA, 1998; Brucker, 2007). Some of the attributable fractions we will be using in this report were originally developed from research conducted as much as 25 years ago.

Third, though an effort was made to replicate the study completed on year 2005 data, slight differences in data sources, revisions in attributable fractions, and changes in methodology 
arose. Differences are noted where applicable. Comparisons between this report and the previous report should therefore be made with caution.

In addition, although efforts were made to obtain Maine data for the year 2010, this was not always possible. In certain cases, national data were used to provide estimates for Maine and were adjusted for inflation or cost of living differences to provide estimates for 2010.

\section{Organization}

The report is organized into eight chapters. Chapters two through seven present cost estimates for each of the six cost areas analyzed: substance abuse treatment, morbidity, mortality, crime, medical care, and other related costs. The final chapter summarizes the findings of the analyses and outlines some policy implications. 


\section{Chapter 2}

\section{Substance Abuse Treatment}

This chapter documents treatment costs in Maine for 2010 and also presents information concerning service utilization. Complete and detailed information regarding treatment costs is difficult to obtain because of the multiplicity of funding sources and the large number of programs. The best source of current information on treatment cost is the Treatment Data System (TDS) maintained by the Maine Office of Substance Abuse (as of September 2012, the Office became the Office of Substance Abuse and Mental Health Services). The service utilization data presented in this chapter are from the TDS.

The following substance abuse treatment services were available in Maine, and those costs are included in the report: residential, outpatient, intensive outpatient, medication assisted therapy, detoxification, shelter, and specialty programs for youth, pregnant women, and persons who have co-occurring mental health and substance use disorders.

\section{The major findings of the analysis were:}

- The total estimated cost of providing treatment in Maine in 2010, based on reported annual revenue, was $\$ 47.0$ million, of which $\$ 45.6$ million is for admissions for treatment, shelter and detoxification, and another $\$ 1.3$ million is for OUI intervention (DEEP).

- Of the \$45.6 million for admissions for treatment, shelter and detoxification, \$36.1 million (79.1\%) is from public funds and $\$ 9.5$ million (20.9\%) is from private funds.

- Of public funds, $53.9 \%$ is from Medicaid Federal portion; $9.2 \%$ is from the federal Substance Abuse Prevention and Treatment Block Grant; 15.8\% is from other federal, state and local funds; $18.3 \%$ is from MaineCare State portion.

- Of private funds, $69.1 \%$ is from Client payments; $30.7 \%$ is from Private Insurance.

- \$1.4 million were spent on DEEP services in 2010, serving approximately 5,500 instate clients.

- Approximately 16,818 admissions to drug and/or alcohol related treatment services, representing 14,996 distinct individuals, were reported during 2010. 


\section{Methodology}

Cost estimates in this chapter were based on discharge data extracted from the Treatment Data System, 2012 (TDS). The data included payer source, number of clients, and the number of units times the cost per unit (see table 2.1). The data in the TDS system are collected from approximately $90 \%$ of the treatment facilities located throughout the State. The proportion of clients whose data are included in TDS is even higher than $90 \%$ because most of the facilities that are not required to report or do not report tend to be small. While all licensed treatment facilities in Maine are required to report to TDS, there were still a few in Maine who had not begun reporting. Primary care providers treating patients in provider's offices do not report to TDS. Therefore the admission counts given are considered to be an underestimate of the total number of persons treated for substance abuse in Maine.

In addition to costs associated with those admitted to treatment, shelter or detoxification, the State conducts an intervention program for those who receive an arrest for OUI (Operating Under the Influence), called the Driver Education and Evaluation Program (DEEP). Cost data on DEEP was extracted from the Maine Department of Administrative and Financial services ${ }^{1}$ financial database. These include all costs: administration in the completion of treatment; Under 21 program; and PRIME FOR LIFE program. Non client administration and out-of-state/military administration were not included in this total. DEEP funding is shown in table 2.2. DEEP is considered a revenue neutral program, where all costs of the program are covered by fees paid by DEEP clients. The fees go into the State General Fund, from which a portion is then returned to the Office of Substance Abuse to pay for program administration.

\section{Results}

Major sources of treatment funding are shown in Tables 2.1 and 2.2. Treatment, shelter, and detoxification costs totaled approximately $\$ 45.6$ million, $79.1 \%$ of which was from public funds (state and federal). The single largest payer source was Medicaid/MaineCare and Medicare, which accounted for $59.3 \%$ of all treatment funding. The second largest source was state and federal government funds (including general and local funds, and federal grant funds), which accounted for 19.8\%. The third largest source was client payments, accounting for 14.4\%

\footnotetext{
${ }^{1}$ These figures do not include the costs associated with treatment by private physicians prescribing buprenorphine (Suboxone and subutex).
} 
of all funding. DEEP funding adds an additional $\$ 1.4$ million for a total of $\$ 47.0$ million for intervention and treatment.

Table 2.1

Treatment funding by payer

Maine, 2010 ${ }^{2}$

\begin{tabular}{|c|c|c|c|c|c|}
\hline Public & 2010 & $\%$ Total & $\begin{array}{l}\text { Attrib. Alc } \\
22.2 \%\end{array}$ & $\begin{array}{c}\text { Attrib. Drug } \\
28.88 \%\end{array}$ & $\begin{array}{c}\text { Attrib. Alc \& } \\
\text { Drug } 49 \%\end{array}$ \\
\hline OSA & $\$ 3,248,277$ & $7.1 \%$ & $\$ 721,117$ & $\$ 938,102$ & $\$ 1,591,656$ \\
\hline Medicaid Fed & $\$ 19,459,027$ & $42.7 \%$ & $\$ 4,319,904$ & $\$ 5,619,767$ & $\$ 9,534,923$ \\
\hline Medicaid State & $\$ 6,590,541$ & $14.4 \%$ & $\$ 1,463,100$ & $\$ 1,903,348$ & $\$ 3,229,365$ \\
\hline Medicare & $\$ 1,014,229$ & $2.2 \%$ & $\$ 225,159$ & $\$ 292,909$ & $\$ 496,972$ \\
\hline SA BG & $\$ 3,307,877$ & $7.3 \%$ & $\$ 734,349$ & $\$ 955,315$ & $\$ 1,620,860$ \\
\hline Other & $\$ 2,461,790$ & $5.4 \%$ & $\$ 546,517$ & $\$ 710,965$ & $\$ 1,206,277$ \\
\hline Total Public & $\$ 36,081,741$ & $79.1 \%$ & $\$ 8,010,147$ & $\$ 10,420,407$ & $\$ 17,680,053$ \\
\hline \multicolumn{6}{|l|}{ Private } \\
\hline Client Payment & $\$ 6,589,056$ & $14.4 \%$ & $\$ 1,462,770$ & $\$ 1,902,919$ & $\$ 3,228,637$ \\
\hline Private Insurance & $\$ 2,928,691$ & $6.4 \%$ & $\$ 650,169$ & $\$ 845,806$ & $\$ 1,435,059$ \\
\hline Other Funding & $\$ 11,591$ & $0.0 \%$ & $\$ 2,573$ & $\$ 3,347$ & $\$ 5,679$ \\
\hline Total Private & $\$ 9,529,337.15$ & $20.9 \%$ & $\$ 2,115,513$ & $\$ 2,752,073$ & $\$ 4,669,375$ \\
\hline TOTAL 2010 & $\$ 45,611,078.26$ & & & & \\
\hline
\end{tabular}

Table 2.2

DEEP funding

Maine, 2010

\begin{tabular}{lcc}
\hline \multicolumn{1}{c}{ DEEP } & \\
& $\mathbf{2 0 1 0}$ \\
\hline DEEP - Self-Pay to General Fund & $\$$ & $1,364,822$ \\
\hline Source: Maine DHHS Financial database & &
\end{tabular}

Data gathered through TDS includes information about treatment services, utilization and program capacity. Data can be broken down by type of disorder and type of service setting. Admissions include persons who reported a primary problem of substance use as well as affected others such as family members. Of all admissions $(16,818)$ for treatment in $2010,78.5 \%$ were for outpatient services (Table 2.3); 28.8\% of admissions were for drug problems only, 22.2\% were for alcohol problems only, and the remaining $49.0 \%$ of admissions were for treatment of combined alcohol and drug problems. There were approximately 5,500 in-state clients served by DEEP in calendar year 2010

\footnotetext{
${ }^{2}$ In this and later tables “Attrib.” refers to the amount of the cost attributed to alcohol or drugs
} 
Table 2.3

Number of admissions for treatment by type of disorder

Maine, 2010

\begin{tabular}{|c|c|c|c|c|}
\hline \multirow[t]{2}{*}{ Type of disorder } & \multicolumn{2}{|c|}{ Treatment type } & Total & \multirow[t]{2}{*}{$\begin{array}{c}\text { Percent } \\
(\%)\end{array}$} \\
\hline & Inpatient & Outpatient & & \\
\hline Alcohol disorder & 1,044 & 2,695 & 3,739 & 22.2 \\
\hline Drug disorder & 800 & 4,037 & 4,837 & 28.8 \\
\hline *Dual disorder & 1,764 & 6,478 & 8,242 & 49.0 \\
\hline Total & 3,608 & 13,210 & 16,818 & 100.00 \\
\hline Percent & (21.5) & (78.5) & & \\
\hline
\end{tabular}

Source: SAMHS/TDS

*Dual disorder are those who have both an alcohol and drug disorder combined.

Persons may be admitted to treatment multiple times over the course of a year, either as new admissions to different facilities for different levels of care or as re-admissions to the same facilities or levels of care. Table 2.4 shows that these 16,818 admissions represented 14,996 individual clients. $79.3 \%$ of the (unduplicated) clients were admitted to outpatient services.

Table 2.4

Number of clients receiving treatment by type of disorder Maine, 2010

\begin{tabular}{lrrrr}
\hline \multicolumn{1}{c}{ Type of disorder } & \multicolumn{2}{c}{ Treatment type } & Total & $\begin{array}{c}\text { Percent } \\
\text { (\%) }\end{array}$ \\
\hline & Inpatient & Outpatient & & \\
\hline Alcohol disorder & 902 & 2,559 & 3,461 & 23.1 \\
Drug disorder & 704 & 3,588 & 4,292 & 28.6 \\
Dual disorder & 1,491 & 5,752 & 7,243 & 48.3 \\
\hline Total & $\mathbf{3 , 0 9 7}$ & $\mathbf{1 1 , 8 9 9}$ & $\mathbf{1 4 , 9 9 6}$ & $\mathbf{1 0 0 . 0 0}$ \\
Percent & $\mathbf{( 2 0 . 7 )}$ & $\mathbf{( 7 9 . 3 )}$ & & \\
\hline
\end{tabular}

Source: SAMHS/TDS

*Dual disorder are those who have both an alcohol and drug disorder combined.

As shown in Table 2.5, 93.9\% of all admissions to treatment were categorized as White clients, 2.6\% were Black, 2.2\% were American Indian/Alaskan Native, and the remaining small portion included "Asians" and clients of other races. The demographic profile of the state population overall is shown in the last column of Table 2.5. In general, the treatment population reflects the state population, although Black and Native American clients are over- represented in the treatment population and Whites and other races are under-represented, when compared to the US Census distribution in Maine. 
Table 2.5

Admissions for treatment by race

Maine, 2010

\begin{tabular}{|c|c|c|c|c|}
\hline Race & Inpatient & Outpatient & $\begin{array}{c}\text { Treatment } \\
\text { population } \\
(\%)\end{array}$ & $\begin{array}{c}\text { State } \\
\text { population } \\
(\%)\end{array}$ \\
\hline White & 3,466 & 12,341 & $\begin{array}{r}15,807 \\
(93.9)\end{array}$ & $\begin{array}{r}1,264,971 \\
(95.2)\end{array}$ \\
\hline Black & 76 & 353 & $\begin{array}{r}429 \\
(2.6)\end{array}$ & $\begin{array}{r}15,707 \\
(1.2)\end{array}$ \\
\hline American Indian/Alaskan Native & 40 & 331 & $\begin{array}{r}371 \\
(2.2)\end{array}$ & $\begin{array}{r}8,568 \\
(0.6)\end{array}$ \\
\hline Other & 26 & 185 & $\begin{array}{r}211 \\
(1.3)\end{array}$ & $\begin{array}{r}39,115 \\
(2.9) \\
\end{array}$ \\
\hline Total & 3,608 & 13,210 & 16,818 & $1,328,361$ \\
\hline
\end{tabular}

*Due to the small cell size, "Asian” was placed within the "Other" category to protect confidentiality

As shown in Table 2.6, approximately 7\% of admissions were clients under age 18, $18.5 \%$ were age $18-24,31.6 \%$ were age $25-34$, 28.5\% were age $35-49$, $13 \%$ were age $50-64$, and $1.4 \%$ were 65 or older. Outpatient services comprised 13,210 admissions, $78.5 \%$ of all admissions.

Table 2.6

Admissions for treatment by age

Maine, 2010

\begin{tabular}{|c|c|c|c|c|}
\hline Age group & Inpatient & Outpatient & $\begin{array}{c}\text { Treatment } \\
(\%)\end{array}$ & $\begin{array}{c}\text { State } \\
\text { population } \\
(\%)\end{array}$ \\
\hline Under 18 & 62 & 1,111 & $\begin{array}{r}1,173 \\
(7.0)\end{array}$ & $\begin{array}{r}274,533 \\
(20.7)\end{array}$ \\
\hline $18-24$ & 450 & 2,662 & $\begin{array}{c}3,112 \\
(18.5)\end{array}$ & $\begin{array}{r}116,072 \\
(8.7)\end{array}$ \\
\hline $25-34$ & 1,004 & 4,310 & $\begin{array}{l}5,314 \\
(31.6)\end{array}$ & $\begin{array}{r}144,624 \\
(10.9)\end{array}$ \\
\hline $35-49$ & 1,330 & 3,464 & $\begin{array}{r}4794 \\
(28.5)\end{array}$ & $\begin{array}{r}278,995 \\
(21.0)\end{array}$ \\
\hline $50-64$ & 699 & 1,491 & $\begin{array}{r}2,190 \\
(13.0)\end{array}$ & $\begin{array}{r}303,057 \\
(22.8)\end{array}$ \\
\hline $65+$ & 63 & 172 & $\begin{array}{r}235 \\
(1.4)\end{array}$ & $\begin{array}{r}211,080 \\
(15.9)\end{array}$ \\
\hline Total & 3,608 & 13,210 & $\begin{array}{r}16,818 \\
(100.0) \\
\end{array}$ & $\begin{array}{r}1,328,361 \\
(100.0) \\
\end{array}$ \\
\hline
\end{tabular}

Source: SAMHS/TDS 


\section{Summary and Implications}

Treatment costs in Maine in 2010 were estimated at $\$ 45.6$ million $^{3}$, representing a per capita expenditure of approximately $\$ 34.33$ (a 79.7\% increase per capita since 2005), using the 2010 US Census population of 1,328,361 Maine residents. The largest funding source remained the same in 2010 as in 2005, government funding, but the amount of client self-pay in 2010 was over 9 times higher than in 2005.

Despite the large amount spent for treatment, this expenditure represents only a fraction of the estimated need. According to a two year annual average of 2010-2011 National Survey of Drug Use and Health (NSDUH) approximately 6.8\% (+/-1.8\%) of the Maine population aged 18 or over needed treatment for an alcohol and/or drug problem. (SAMHSA, 2013) Using this percentage, and based on the 2010 US Census, which estimates 1,053,828 adult residents living in Maine, approximately 71,660 adults, were in need of treatment for alcohol and/or drug addiction. In 2010, only 14,996 individuals were reported to have received treatment, which is $20.9 \%$ of the total number of individuals who needed treatment.

The total amount of resources devoted to treatment and intervention, $\$ 47.0$ million, is only about 3.4\% of the total cost of substance abuse in Maine, $\$ 1.381$ billion.

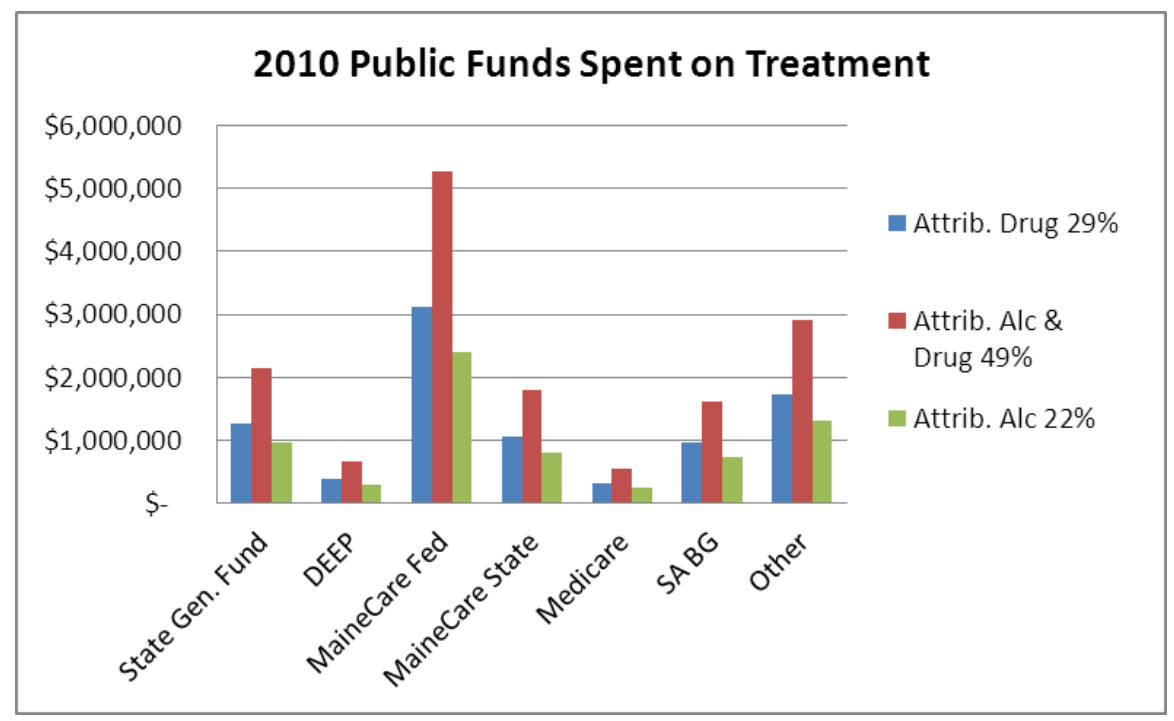

Figure 2.1

\footnotetext{
${ }^{3}$ This total excludes the OUI intervention program, DEEP.
} 


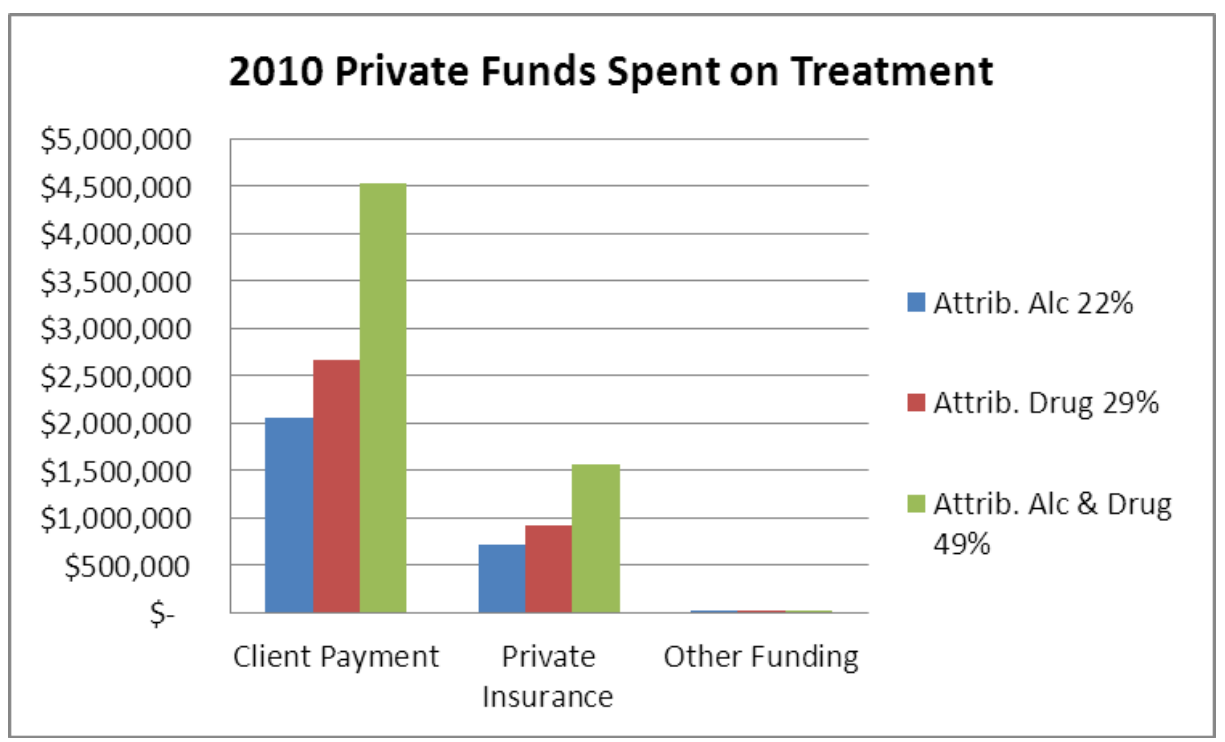

Figure 2.2 


\section{Chapter 3}

\section{Morbidity}

Alcohol and drug use, abuse, or dependence may adversely affect the ability of an individual to participate in work or other activities, such as maintaining a household. This chapter measures morbidity costs as reduced productivity from alcohol and drug abuse, measured in terms of either wage earnings for workers or housekeeping values for non-workers.

\section{The major findings of the analysis were:}

- Total morbidity costs in 2010 due to alcohol or drug abuse were \$188.6 million;

- Males accounted for $75.9 \%$ of total costs;

- Males aged 45-64 accounted for the largest portion of alcohol morbidity costs.

\section{Methodology}

This chapter generally follows the established methodology used in previous Maine studies and other studies nationally to estimate morbidity costs associated with alcohol or drug use (Baird et al., 2004; Wickizer, 1999; Rice et al., 1990).

First, the number of persons with a drug abuse disorder, the number with an alcohol abuse disorder, and the total number with either or both substance use disorders were estimated based upon prevalence data gathered for Maine by the federal survey, $\mathrm{NSDUH}^{4}$. Due to relatively small NSDUH sample sizes each year, data from 2006 through 2009 (SAMHSA, 2011) had to be combined to develop reasonably reliable prevalence estimates, and were then weighted by age/gender proportions from the 2010 Census. Then the prevalence rates were applied to Maine Census population estimates for the year 2010 (U.S. Census Bureau, 2010) to estimate the numbers of persons within each age group and gender category who met the criteria for a substance disorder. The number of persons who met criteria for a substance disorder in each age/gender category was multiplied by the labor force participation rate within each subgroup to estimate the expected number who would be employed. Next, the number of persons with a substance use disorder who were not employed was estimated by subtracting the

\footnotetext{
${ }^{1}$ Total persons with a substance abuse disorder is less than the sum of persons with an alcohol or drug abuse disorder because some persons have both disorders.
} 
number of employed persons from the total number of persons who met the substance disorder criteria.

Median earnings for male and female age groups were estimated by adjusting the earnings listed in the 2005 Cost Report (OSA, 2007). The alcohol and drug use disorder impairment rates were determined by averaging the rates used by Wickizer (1999). To develop an estimate of an impairment rate to apply to the alcohol or drug use disorder estimates, the impairment rates for the two separate categories were weighted according to the percentage of age specific prevalence reported from the NSDUH. ${ }^{5}$

Median earnings for each age/gender/labor participation group were multiplied by the relevant impairment rate to generate estimates of lost earnings due to drug and alcohol abuse. ${ }^{6}$

\section{Results}

Approximately 80,091 adults in Maine had an alcohol use disorder in 2010; 29,507 adults had a drug use disorder, and 99,060 adults had either or both disorders (Table 3.1).

The prevalence of abuse or dependence was highest among the 18-24 year old age group. The prevalence of alcohol abuse or dependence was $22.1 \%$ for males and $13.4 \%$ for females in the $18-24$ year old age group. An estimated $10.4 \%$ of males and $10.9 \%$ of females in that age group met the criteria for drug abuse or dependence. Criteria for illicit drug or alcohol abuse or dependence were met by $27.4 \%$ of males and $20.2 \%$ of females in the $18-24$ year old age group.

Based upon the labor force participation rates included in Table 3.2, an estimated 56,685 employed persons had an alcohol use disorder, at least 21,854 employed persons had a drug use disorder, and an estimated 70,824 employed persons had either or both disorders in Maine in 2010. Of persons who were not participating in the labor force, an estimated 17,095 persons were estimated to have an alcohol use disorder, 7,435 persons had a drug use disorder, and 21,881 persons had either or both disorders.

\footnotetext{
${ }^{5}$ See Appendix A for details of the calculations.

${ }^{6}$ See Appendix A for details of the calculations.
} 
Table 3.1

Estimated number of adults with abuse or dependence, by gender and age

Maine, 2006-2009

\begin{tabular}{|c|c|c|c|c|c|c|c|}
\hline & $\begin{array}{l}\text { Alcohol } \\
\text { disorder } \\
\text { prevalence }\end{array}$ & $\begin{array}{c}\text { Drug } \\
\text { disorder } \\
\text { prevalence }\end{array}$ & $\begin{array}{c}\text { Alcohol } \\
\text { and/or drug } \\
\text { disorder } \\
\text { prevalence }\end{array}$ & $\begin{array}{c}2010 \\
\text { Maine } \\
\text { Population }\end{array}$ & $\begin{array}{l}\text { Alcohol } \\
\text { disorder }\end{array}$ & $\begin{array}{c}\text { Drug } \\
\text { disorder }\end{array}$ & $\begin{array}{l}\text { Alcohol } \\
\text { and/or } \\
\text { drug } \\
\text { disorder }\end{array}$ \\
\hline & $\%$ & $\%$ & $\%$ & $\mathbf{N}$ & $\mathbf{N}$ & $\mathbf{N}$ & $\mathbf{N}$ \\
\hline \multicolumn{8}{|l|}{ Male } \\
\hline $18-24$ & 22.1 & 10.4 & 27.4 & 59,258 & 13,096 & 6,163 & 16,237 \\
\hline $25-44$ & 13.7 & 4.5 & 15.8 & 156,066 & 21,381 & 7,023 & 24,658 \\
\hline $45-64$ & 8.6 & 2.1 & 10.7 & 201,212 & 17,304 & 4,225 & 21,530 \\
\hline $65+$ & * & * & * & 92,468 & * & * & $*$ \\
\hline Total & 11.1 & 3.5 & 13.2 & 509,004 & 56,499 & 17,815 & 67,189 \\
\hline \multicolumn{8}{|l|}{ Female } \\
\hline $18-24$ & 13.4 & 10.9 & 20.2 & 56,814 & 7,613 & 6,193 & 11,476 \\
\hline $25-44$ & 6.9 & 2.9 & 9.4 & 159,934 & 11,035 & 4,638 & 15,034 \\
\hline $45-64$ & 1.6 & 0.5 & 1.8 & 209,464 & 3,351 & 1,047 & 3,770 \\
\hline $65+$ & * & * & * & 118,612 & * & * & * \\
\hline Total & 4.4 & 2.3 & 6.0 & 544,824 & 23,972 & 12,531 & 32,689 \\
\hline TOTAL & 7.6 & 2.8 & 9.4 & $1,053,828$ & 80,091 & 29,507 & 99,060 \\
\hline
\end{tabular}

Sources: SAMHSA, 2011; US Census, 2010 
Table 3.2

Estimated number of adults with substance abuse or dependence, by gender, age, and employment status

Maine, 2010

\begin{tabular}{|c|c|c|c|c|c|c|c|c|c|c|}
\hline & $\begin{array}{l}\text { Alcohol } \\
\text { disorder }\end{array}$ & $\begin{array}{c}\text { Drug } \\
\text { disorder }\end{array}$ & $\begin{array}{l}\text { Alcohol } \\
\text { and/or } \\
\text { drug } \\
\text { disorder }\end{array}$ & $\begin{array}{c}\text { Labor force } \\
\text { participation } \\
\text { rate }\end{array}$ & & Employed & & & t employed & \\
\hline & $\mathbf{N}$ & $\mathbf{N}$ & $\mathbf{N}$ & $\%$ & $\begin{array}{l}\text { Alcohol } \\
\text { disorder }\end{array}$ & $\begin{array}{c}\text { Drug } \\
\text { disorder }\end{array}$ & $\begin{array}{l}\text { Alcohol } \\
\text { and/or } \\
\text { drug } \\
\text { disorder }\end{array}$ & $\begin{array}{l}\text { Alcohol } \\
\text { disorder }\end{array}$ & $\begin{array}{c}\text { Drug } \\
\text { disorder }\end{array}$ & $\begin{array}{l}\text { Alcohol } \\
\text { and/or } \\
\text { drug } \\
\text { disorder }\end{array}$ \\
\hline \multicolumn{11}{|l|}{ Male } \\
\hline $18-24$ & 13,096 & 6,163 & 16,237 & 61.6 & 8067 & 3796 & 10002 & 5029 & 2367 & 6235 \\
\hline $25-44$ & 21,381 & 7,023 & 24,658 & 89.4 & 19115 & 6279 & 22044 & 2266 & 744 & 2614 \\
\hline $45-64$ & 17,304 & 4,225 & 21,530 & 77.4 & 13393 & 3270 & 16664 & 3911 & 955 & 4866 \\
\hline $65+$ & $*$ & $*$ & $*$ & 21.6 & $*$ & $*$ & $*$ & * & $*$ & * \\
\hline \multicolumn{11}{|l|}{ Female } \\
\hline $18-24$ & 7,613 & 6,193 & 11,476 & 66.7 & 5078 & 4131 & 7654 & 2535 & 2062 & 3822 \\
\hline $25-44$ & 11,035 & 4,638 & 15,034 & 78.2 & 8629 & 3627 & 11757 & 2406 & 1011 & 3277 \\
\hline $45-64$ & 3,351 & 1,047 & 3,770 & 71.7 & 2403 & 751 & 2703 & 948 & 296 & 1067 \\
\hline $65+$ & $*$ & $*$ & $*$ & 13.9 & $*$ & $*$ & $*$ & $*$ & $*$ & $*$ \\
\hline
\end{tabular}

Sources: SAMHSA, 2011; US Census, 2010; US Dept of Labor 2010 
Median annual wages in Maine in 2010 ranged from a low of \$16,227 for males aged 65 and older to \$46,447 for males aged 45-64 (Table 3.3). Housekeeping values, which represent imputed market values for maintaining the home, are also included in Table 3.3. Employment earnings do not capture all of the productive capacity of individuals, because people have to maintain households apart from their jobs. Thus, Table 3.3 includes two sets of housekeeping values, one for persons in the labor force, the second for persons not in the labor force. Housekeeping values are significantly higher for females than males, reflecting the relative amount of time spent in this activity. These housekeeping values were calculated by taking the values from the 2005 Cost Report and adjusting for inflation (14.93\% from 2005 to 2010, InflationData.com).

Table 3.3

Morbidity costs

Maine, 2010

\begin{tabular}{|c|c|c|c|c|c|c|c|c|c|c|c|c|c|c|c|}
\hline & \multicolumn{3}{|c|}{ Employed } & \multicolumn{3}{|c|}{ Not in labor force } & \multirow[t]{2}{*}{$\begin{array}{c}\text { Median } \\
\text { earnings }\end{array}$} & \multicolumn{2}{|c|}{ Housekeeping } & \multicolumn{3}{|c|}{ Impairment rates } & \multicolumn{3}{|c|}{ Morbidity costs } \\
\hline & $\begin{array}{l}\text { Alcohol } \\
\text { disorder }\end{array}$ & $\begin{array}{c}\text { Drug } \\
\text { disorder }\end{array}$ & $\begin{array}{c}\text { Alcohol } \\
\text { and/or } \\
\text { drug } \\
\text { disorder } \\
\end{array}$ & $\begin{array}{l}\text { Alcohol } \\
\text { disorder }\end{array}$ & $\begin{array}{c}\begin{array}{c}\text { Drug } \\
\text { disorder }\end{array} \\
\end{array}$ & $\begin{array}{c}\text { Alcohol } \\
\text { and/or } \\
\text { drug } \\
\text { disorder }\end{array}$ & & $\begin{array}{l}\text { In } \\
\text { labor } \\
\text { force }\end{array}$ & $\begin{array}{l}\text { Not in } \\
\text { labor } \\
\text { force }\end{array}$ & Alcohol & Drugs & $\begin{array}{l}\text { Alcohol } \\
\text { and/or } \\
\text { drugs }\end{array}$ & Alcohol & Drugs & $\begin{array}{c}\text { Alcohol } \\
\text { and/or } \\
\text { drugs }\end{array}$ \\
\hline & $\mathbf{N}$ & $\mathbf{N}$ & $\mathbf{N}$ & $\mathbf{N}$ & $\mathbf{N}$ & $\mathbf{N}$ & $\$$ & $\$$ & $\$$ & & & & $\$$ & $\$$ & $\$$ \\
\hline \multicolumn{16}{|l|}{ Male } \\
\hline $18-24$ & 8,067 & 3,796 & 10,002 & 5,029 & 2,367 & 6,235 & 26,127 & 3,910 & 8,103 & 1.40 & 1.10 & 1.61 & $3,962,819$ & $1,465,203$ & $5,650,332$ \\
\hline $25-44$ & 19,115 & 6,279 & 22,044 & 2,266 & 744 & 2,614 & 40,641 & 4,918 & 9,186 & 4.25 & 5.45 & 5.17 & $37,896,220$ & $15,963,014$ & $53,163,875$ \\
\hline $45-64$ & 13,393 & 3,270 & 16,664 & 3,911 & 955 & 4,866 & 46,447 & 5,326 & 9,604 & 7.40 & 7.80 & 7.40 & $54,090,820$ & $13,920,623$ & $67,301,397$ \\
\hline \multirow[t]{2}{*}{$65+$} & * & * & * & * & * & * & 16,227 & 3,973 & 7,550 & 9.30 & 7.30 & * & $*$ & $*$ & $*$ \\
\hline & & & & & & & & & & & & & $95,949,859$ & $31,348,840$ & $126,115,604$ \\
\hline \multicolumn{16}{|l|}{ Female } \\
\hline $18-24$ & 5078 & 4131 & 7654 & 2535 & 2062 & 3822 & 19,882 & 12,367 & 20,474 & 0.80 & 0.20 & 0.65 & $1,725,296$ & 350,876 & 2,113,056 \\
\hline $25-44$ & 8629 & 3627 & 11757 & 2406 & 1011 & 3277 & 26,796 & 14,658 & 22,718 & 7.35 & 1.45 & 6.74 & $30,308,906$ & $2,513,163$ & $37,866,773$ \\
\hline $45-64$ & 2403 & 751 & 2703 & 948 & 296 & 1067 & 34,835 & 12,938 & 21,092 & 15.30 & 4.55 & 14.87 & $20,623,441$ & $1,916,494$ & $22,542,231$ \\
\hline \multirow[t]{2}{*}{$65+$} & * & * & * & * & * & * & 16,257 & 6,142 & 10,068 & 18.70 & 7.30 & * & $*$ & $*$ & $*$ \\
\hline & & & & & & & & & & & & & $52,657,644$ & $4,780,533$ & $62,522,060$ \\
\hline TOT & LEST & & & & & & & & & & & & $148,607,503$ & $36,129,373$ & $\$ 188,637,664$ \\
\hline
\end{tabular}

Sources: US Census Bureau, 2010; Baird, Lanctot and Clough, 2004; Rice et al., 1990 
Table 3.3 uses impairment rates for different age-gender groups for alcohol and drugs. ${ }^{7}$ These impairment rates provide an estimate of reduced productivity, measured by earnings, associated with drug and alcohol use disorder. For example, the alcohol impairment rate of $7.4 \%$ for males aged 45-64 indicates that males in this age group would, on average, earn 7.4\% less than males of a similar age who did not have an alcohol disorder.

Total morbidity costs for alcohol in 2010 were estimated at \$148,607,503. Males accounted for $64.6 \%(\$ 95,949,859)$ of these costs. Total morbidity costs for drugs were $\$ 36,129,373$ million, with $86.8 \%(\$ 31,348,840)$ of this cost attributable to males. Total morbidity cost for alcohol and/or drug use is estimated at \$188,637,664 million in 2010.

\section{Summary}

Alcohol and drug abuse result in substantial economic loss to Maine by reducing productivity. Total morbidity costs for 2010 for alcohol or drug use were estimated at $\$ 188.6$ million. Compared with 2005 estimates, costs associated with alcohol abuse were higher in 2010, estimated at $\$ 148.6$ million, compared to a cost of $\$ 135.7$ million in 2005. Costs associated with drug abuse were higher in 2010 (\$36.1 million) than drug abuse morbidity costs in 2005 (\$17.3 million). One reason for the substantial increase is that this cost estimate had a more complete data set than the estimate completed in 2005.

\footnotetext{
${ }^{7}$ The impairment rates for alcohol and drug use were adapted from Rice et al., 1990 (Table 40).
} 


\section{Chapter 4}

\section{Mortality}

Premature death due to drug and alcohol use and abuse imposes a major economic cost on society. Premature death through illness or injury can occur through auto accidents involving alcohol, through increasing the risk of cancer or cerebrovascular disease, or through violence involving drugs or alcohol. When an individual dies prematurely, there is an economic cost to society in the form of loss of that individual's productive capacity.

This chapter analyzes mortality costs for Maine in 2010. It has three aims:

1. To determine the number of alcohol- and drug-related deaths.

2. To estimate the number of years of potential life lost from these deaths.

3. To estimate the total economic costs of drug- and alcohol-related deaths.

\section{The major findings of the analysis were:}

- 713 deaths related to drug and alcohol abuse occurred in 2010, (538 alcohol-related and 175 drug-related deaths), resulting in 15,896 years of potential life lost.

- Major causes of death were:

a. cancer (various types) - 132 deaths

b. accidental drug poisoning -128 deaths

c. cirrhosis and liver damage -102 deaths

d. motor vehicle accidents -66 deaths

e. suicide - 52 deaths and 31 deaths from drugs

- Total mortality costs for 2010 were $\$ 409.6$ million. Of this amount, $58.8 \%$ resulted from alcohol abuse and $41.2 \%$ from drug abuse.

- The average cost per death in 2010 , measured in lost earnings, was $\$ 574,534$.

- Drugs accounted for a higher relative proportion of the costs per death than did alcohol. Only $24.5 \%$ of deaths were attributable to drugs, yet $41.2 \%$ of costs were attributable to drugs,

- With drug deaths tending to occur at younger ages than alcohol deaths, the number of years of life lost per person on average was higher in drug related deaths. 


\section{Methodology}

In brief, three steps were followed. First, the number of deaths due to diseases associated either directly or indirectly with alcohol or drug use was obtained from the death certificate file of the Maine Office of Data, Research and Vital Statistics (ODRVS), Department of Health and Human Services (DHHS, 2012) ${ }^{8}$. The authors of this report were informed that in 2010 there were many death certificates entered into the death database system as "unknown" for the cause of death, so a complete picture of the drug deaths was not available. Therefore the authors decided to use the data from the State Medical Examiner's Office to provide a more accurate estimation of drug related deaths in 2010. Alcohol Attributable Fractions (AAF) and Drug Attributable Fractions (DAF) used by NIDA/NIAAA were applied to the data to estimate the number of alcohol- and drug-related deaths in Maine for non-substance categories. A review of the literature, was performed to check for any updates to industry standards in calculating year per life lost and cost attribution. This report uses the methodology in Economic Costs of Excessive Alcohol Consumption, 2006 produced by the Lewin group. Because of this change in methodology, caution should be used when trying to compare Maine cost reports 2005 and 2010.

Second, the mortality cost for each age-gender cohort was determined by using the same cost per potential life lost as used by The Lewin Group (2010) and Max, D., et. al. (2004). An average net present value (NPV) with 3\% discount was obtained by using table IV-11 in the 2010 Lewin Group Economic Cost of Excessive Alcohol Consumption report to calculate the average per age/gender group cost used in this report. Cost figures were adjusted for inflation from the 2006 rate estimates by The Lewin Group (2010) using the inflation cost calculator (InflationData.com, 2012) based upon the CPI for 2010. This produced the "net present value of future earnings" as shown in table 4.4a. This is a different methodology than was used in the 2005 Maine Cost report, but has been used by Federal agencies such as the US Center for Disease Control and the US Department of Justice, among many other highly respected organizations. The final adjusted mortality cost figure was then multiplied by the number of substance-related deaths in Maine. To further adjust for difference in median income rates between Maine and the US, total drug and alcohol costs were multiplied by .9383 to calculate the total loss overall (which is the percent of Maine wages compared to national wages).

\footnotetext{
${ }^{8}$ Preliminary data for drug related deaths were provided by the Office of Chief Medical Examiner, pending final data from Vital Statistics.
} 
Third, the number of years of potential life lost was calculated for each age group and gender by first determining Maine’s current life expectancy by gender obtained from the Social Science Research Council, Measure of America (www.measureofamerica.org). The life expectancy at birth for females in Maine was 81 years; for males it was 76 years.

\section{Results}

There were 713 deaths in Maine in 2010 related to drug or alcohol use. A breakdown of the deaths by age and gender is shown in Table 4.1. Alcohol accounted for $75.5 \%$ of the substance abuse deaths, and older persons represented the greatest proportion of alcohol related deaths (ARD) particularly those 55-64 (21.0\%) and 65 and over (48.3\%). In contrast, the highest proportion of drug-related deaths (DRD) was among middle aged adults 35-44 (25.7\%) and 4554 (29.1\%) (see Figure 4.1).

Table 4.1

Number of alcohol and drug related deaths by age and gender Maine 2010

\begin{tabular}{|c|c|c|c|c|c|c|c|}
\hline & \multicolumn{3}{|c|}{ Alcohol related deaths } & \multicolumn{3}{|c|}{ Drug related deaths } & \multirow[t]{2}{*}{ Total } \\
\hline & Female & Male & Total & Female & Male & Total & \\
\hline \multirow{2}{*}{ Age } & $\mathrm{N}$ & $\mathrm{N}$ & $\mathrm{N}$ & $\mathrm{N}$ & $\mathrm{N}$ & $\mathrm{N}$ & $\mathrm{N}$ \\
\hline & $(\%)$ & $(\%)$ & $(\%)$ & $(\%)$ & $(\%)$ & $(\%)$ & $(\%)$ \\
\hline \multirow{2}{*}{$1-18$} & 3 & 10 & 13 & 1 & 0 & 1 & 14 \\
\hline & (1.6) & $(2.8)$ & (2.4) & $(0.0)$ & $(0.0)$ & $(0.0)$ & $2.0 \%$ \\
\hline \multirow{2}{*}{$19-24$} & 5 & 14 & 19 & $5 *$ & $11 *$ & 16 & 35 \\
\hline & $(2.7)$ & (3.9) & (3.5) & $(8.0)$ & $(17.5)$ & $(13.8)$ & $4.9 \%$ \\
\hline \multirow{2}{*}{$25-34$} & 4 & 16 & 20 & $10^{*}$ & $18^{*}$ & 28 & 48 \\
\hline & $(2.2)$ & (4.5) & (3.7) & $(12.0)$ & (27.5) & $(21.5)$ & $6.7 \%$ \\
\hline \multirow{2}{*}{$35-44$} & 9 & 12 & 21 & $21 *$ & $24 *$ & 45 & 66 \\
\hline & (4.9) & (3.3) & (3.9) & $(32.0)$ & (22.5) & (26.2) & $9.3 \%$ \\
\hline \multirow{2}{*}{$45-54$} & 23 & 65 & 88 & $19 *$ & $32 *$ & 51 & 139 \\
\hline & (12.6) & (18.1) & (16.4) & (32.0) & (27.5) & (29.2) & $19.5 \%$ \\
\hline \multirow{2}{*}{$55-64$} & 35 & 82 & 113 & $9 *$ & $9 *$ & 18 & 131 \\
\hline & (19.1) & (22.8) & (21.0) & $(4.0)$ & (2.5) & (3.1) & $18.4 \%$ \\
\hline \multirow{2}{*}{$65+$} & 103 & 157 & 260 & 3* & $5^{*}$ & 8 & 268 \\
\hline & (56.3) & $(43.7)$ & (48.3) & (12.0) & (2.5) & (6.2) & $37.6 \%$ \\
\hline Unknown & $\begin{array}{r}1 \\
(0.5)\end{array}$ & $\begin{array}{r}3 \\
(0.8)\end{array}$ & $\begin{array}{r}3 \\
(0.6)\end{array}$ & $\begin{array}{r}5^{*} \\
(12.0)\end{array}$ & $\begin{array}{r}3^{*} \\
(2.5)\end{array}$ & $\begin{array}{r}8 \\
(6.2)\end{array}$ & $\begin{array}{r}12 \\
1.7 \%\end{array}$ \\
\hline \multirow{2}{*}{ Total } & 182 & $359 *$ & $538 *$ & 73 & 102 & 175 & 713 \\
\hline & $(100.0)$ & $(100.0)$ & $(100.0)$ & $(100.0)$ & (100.0) & $(100.0)$ & $(100.0)$ \\
\hline
\end{tabular}

Source: Maine Department of Health and Human Services, Office of Data, Research and Vital Statistics, 2010; * Office of the Chief Medical Examiner, 2013

* 6 unknown age male and 6 unknown age female 
More detailed information concerning alcohol-and drug-related deaths is presented in Tables 4.2 and 4.3, which show how mortality estimates were derived. Table 4.2 includes respective alcohol-attributable fractions (AAF), representing the percentage of deaths within a given diagnosis believed to be attributable to alcohol. For example, the AAF for cancer of the larynx is 0.50 , indicating that research has suggested that 50 percent of deaths linked to this form of cancer could reasonably be associated with alcohol use. Table 4.3 has a column labeled drugattributable fraction (DAF), which provides corresponding information for drug-related deaths. Multiplying the total number of deaths within a diagnostic category by the AAF or DAF gives an estimate of the number of deaths attributable to alcohol or drug use. The AAF and DAF values used for this report are the same as those used in by NIDA/NIAAA (1998).

Table 4.2 shows that different types of cancers accounted for the greatest number of alcohol-related deaths (132), followed by accidental drug poisonings (128), cirrhosis/liver damage (102), alcohol related suicide (52) and cerebrovascular disease (40). Motor vehicle accidents accounted for 66 alcohol-related deaths. Accidental poisoning was the leading cause of drug-related death (128 deaths). (Table 4.3)

Table 4.4a and 4.4b provides detailed information on the number of years of potential life lost (YPLL) due to drug and alcohol use and the estimated economic cost of premature death. In 2010, deaths associated with drug and alcohol use resulted in 15,896 years of potential life lost. Alcohol accounted for a greater proportion (63.2\%) of total years of life lost than drugs (36.7\%). The category representing the single greatest number of years of lost life for those dying of alcohol-related causes was males age 45-54 (1,690 or 16.8\%).

Multiplying lost earnings by the years of life lost can provide an estimate of the economic impact of substance abuse. Cost figures were derived from The Lewin Group (2010) and Max et al. (2004). More details are available in the methodology section. Using this newer methodology is one major factor in the increase (100.1\%) shown between 2005 and 2010 reports, although the numbers of deaths also increased, especially drug related deaths, which tend to occur at younger ages than alcohol related deaths. ${ }^{9}$ Other factors contributing to the increase includes increase in average wages and a slight increase in Maine’s average lifespan.

\footnotetext{
${ }^{9}$ The total drug death numbers reported in the 2005 report were an underestimate of the actual total number of deaths, particularly accidental overdoses.
} 
Premature death due to alcohol and drug use resulted in an estimated economic loss of approximately $\$ 409.6$ million. As reflected in Table 4.4a the estimated economic loss due to premature death in 2010 related to alcohol use was \$240.9 million (\$256.7 adjusted with the .9383 income discount), as compared to $\$ 168.7$ million for drug use. Drug and alcohol-related deaths among males aged 45-54 accounted for the largest single age group costs, \$89.2 million.

\section{Summary}

In 2010, 713 people died in Maine from drug and alcohol-related causes, resulting in 15,898 years of potential life lost. Nearly half of alcohol related deaths occurred in persons 65 or older (Figure 4.1), whereas drug related deaths occurred more often in persons 35-44 and 45-54 years old. Translated into economic terms, this loss of life combined represented an economic cost of approximately $\$ 409.6$ million. Approximately $58.8 \%$ of this cost represents premature death related to alcohol use and abuse.

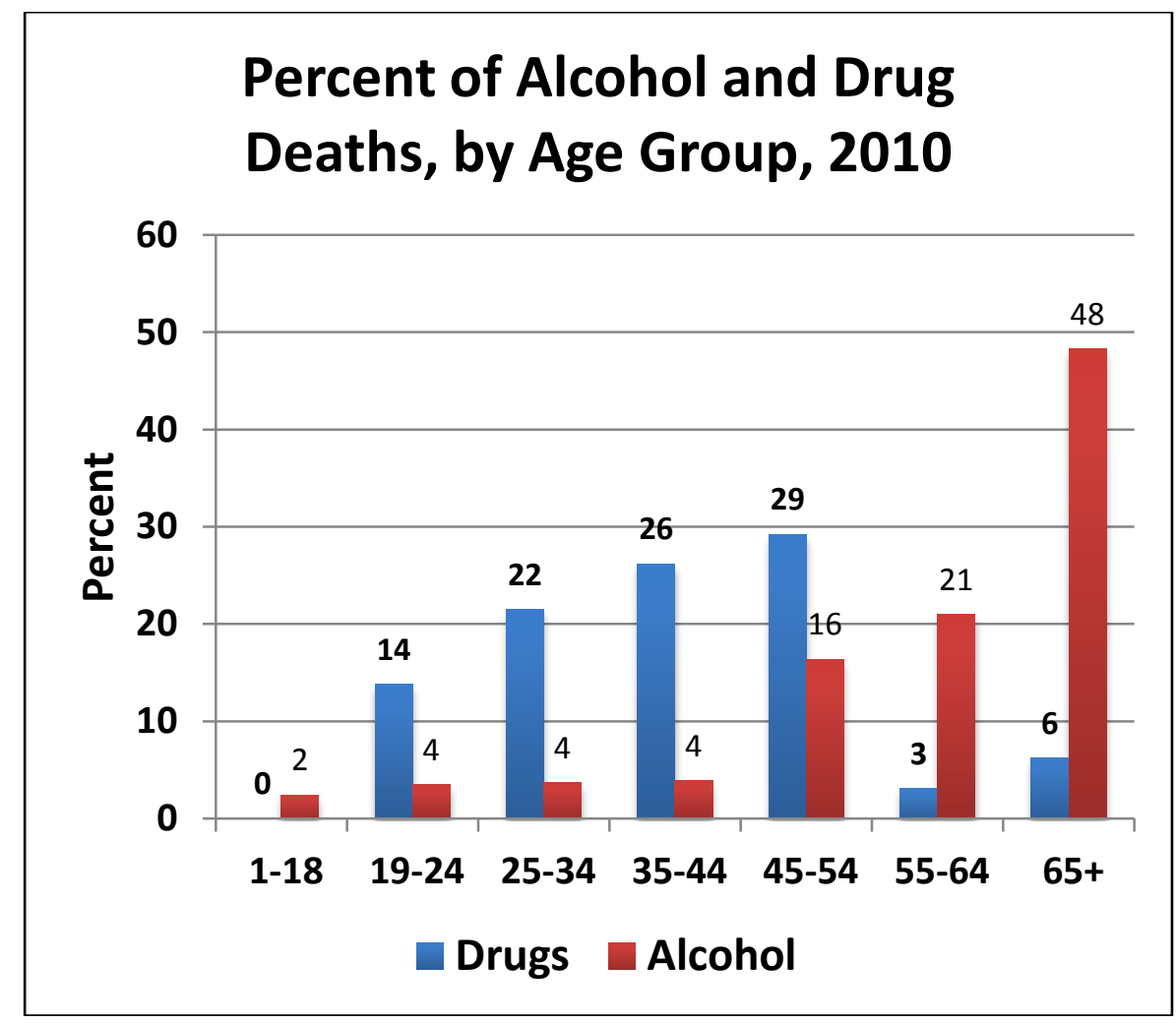

Figure 4.1 
Table 4.2

Deaths attributable to alcohol by diagnosis and gender

Maine, 2010

\begin{tabular}{|c|c|c|c|c|c|c|c|c|c|}
\hline \multirow[b]{2}{*}{ Diagnosis } & \multirow{2}{*}{$\begin{array}{c}\text { ICD-10-CM } \\
\text { diagnostic } \\
\text { codes }\end{array}$} & \multirow[b]{2}{*}{ AAF } & \multirow[b]{2}{*}{$\begin{array}{c}\text { Age } \\
\text { (Years) }\end{array}$} & \multirow[b]{2}{*}{$\begin{array}{l}\text { Total } \\
\text { deaths }\end{array}$} & \multicolumn{2}{|c|}{$\underline{\text { Male }}$} & \multicolumn{2}{|c|}{ Female } & \multirow{2}{*}{$\frac{\text { Total }}{\text { ARD }}$} \\
\hline & & & & & Deaths & ARD & Deaths & ARD & \\
\hline \multicolumn{10}{|l|}{ Direct Causes } \\
\hline Excessive blood levels of alcohol & F10.0 & 1 & $\geq 15$ & 0 & 0 & $\mathbf{0}$ & 0 & $\mathbf{0}$ & $\mathbf{0}$ \\
\hline Alcohol abuse & F10.1 & 1 & $\geq 15$ & 10 & 9 & 9 & 1 & 1 & 10 \\
\hline Alcohol dependence syndrome & F10.2 & 1 & $\geq 15$ & 17 & 16 & 16 & 1 & 1 & 17 \\
\hline Other mental/behavioral problems due to alcohol & F10.3-.9 & 1 & $\geq 15$ & 7 & 4 & 4 & 3 & 3 & 7 \\
\hline Alcoholic cardiomyopathy & I42.6 & 1 & $\geq 15$ & 3 & 2 & 2 & 1 & 1 & 3 \\
\hline Alcoholic fatty liver & K70.0 & 1 & $\geq 15$ & 0 & 0 & $\mathbf{0}$ & 0 & $\mathbf{0}$ & $\mathbf{0}$ \\
\hline Acute alcoholic hepatitis & K70.1 & 1 & $\geq 15$ & 2 & 0 & $\mathbf{0}$ & 2 & 2 & 2 \\
\hline Alcoholic cirrhosis & K70.3 & 1 & $\geq 15$ & 60 & 41 & 41 & 19 & 19 & 60 \\
\hline Alcoholic hepatic failure & K70.4 & 1 & $\geq 15$ & 13 & 7 & 7 & 6 & 6 & 13 \\
\hline Alcoholic liver damage & K70.9 & 1 & $\geq 15$ & 10 & 6 & 6 & 4 & 4 & 10 \\
\hline \multicolumn{10}{|l|}{ Indirect Causes } \\
\hline Respiratory tuberculosis & A15,A16 & 0.25 & $\geq 35$ & 2 & 0 & $\mathbf{0}$ & 2 & $\mathbf{0}$ & $\mathbf{0}$ \\
\hline Malignant neoplasm of the oral cavity ${ }^{10}$ & $\mathrm{C} 00-\mathrm{C} 14$ & 0.50 & $\geq 35$ & 40 & 25 & 13 & 15 & 8 & 21 \\
\hline Malignant neoplasm of the esophagus & C15 & 0.75 & $\geq 35$ & 106 & 85 & 64 & 21 & 16 & 80 \\
\hline Malignant neoplasm of the stomach & C16 & 0.20 & $\geq 35$ & 37 & 21 & 4 & 16 & 3 & 7 \\
\hline Malignant neoplasm of the liver & C22 & 0.15 & $\geq 35$ & 105 & 69 & 10 & 36 & 5 & 15 \\
\hline Malignant neoplasm of the larynx ${ }^{7}$ & C32 & 0.50 & $\geq 35$ & 18 & 16 & 8 & 2 & 1 & 9 \\
\hline Diabetes mellitus & E10-E14 & 0.05 & $\geq 35$ & 365 & 207 & 10 & 158 & 8 & 18 \\
\hline Cerebrovascular disease & G45, I60-I69 & 0.07 & $\geq 35$ & 574 & 229 & 16 & 345 & 24 & 40 \\
\hline Essential hypertension & $\mathrm{I} 10$ & 0.08 & $\geq 35$ & 53 & 24 & 2 & 29 & 2 & 4 \\
\hline Pneumonia and influenza & J10-J18 & 0.05 & $\geq 35$ & 227 & 102 & 5 & 119 & 6 & 11 \\
\hline Diseases of the stomach esophagus, duodenum & $\begin{array}{l}\text { K20-K31(excl. } \\
\text { K29.2) }\end{array}$ & 0.10 & $\geq 35$ & 28 & 12 & 1 & 16 & 2 & 3 \\
\hline Cirrhosis of liver, w/o mention of alcohol & K74.3-K74.6 & 0.50 & $\geq 35$ & 62 & 27 & 14 & 35 & 18 & 32 \\
\hline Portal hypertension & K76.6 & 0.50 & $\geq 35$ & 0 & 0 & $\mathbf{0}$ & 0 & $\mathbf{0}$ & $\mathbf{0}$ \\
\hline Acute pancreatitis & K85 & 0.42 & $\geq 35$ & 11 & 4 & 2 & 7 & 3 & 5 \\
\hline
\end{tabular}

\footnotetext{
${ }^{10}$ The AAF for females is 0.40 .
} 


\section{Unintentional Injuries}

Accidental drowning \& submersions

Accidental falls

Accidents caused by fire \& flames

Air and space transport accidents

Other injuries and adverse effects

Motor vehicle accidents

Pedal cycle \& other road vehicle accidents

Water transport accidents

\begin{tabular}{crlrrrrrr} 
W65-W74 & 0.38 & $\geq 0$ & 22 & 19 & $\mathbf{7}$ & 3 & $\mathbf{1}$ & $\mathbf{8}$ \\
W00-W19 & 0.35 & $\geq 15$ & 76 & 44 & $\mathbf{1 5}$ & 32 & $\mathbf{1 1}$ & $\mathbf{2 6}$ \\
X00-X09 & 0.45 & $\geq 0$ & 7 & 4 & $\mathbf{2}$ & 3 & $\mathbf{1}$ & $\mathbf{3}$ \\
V95-V97 & 0.16 & $\geq 0$ & 5 & 5 & $\mathbf{1}$ & 0 & $\mathbf{0}$ & $\mathbf{1}$ \\
${ }_{11}$ & 0.25 & $\geq 15$ & 18 & 12 & $\mathbf{3}$ & 6 & $\mathbf{2}$ & $\mathbf{5}$ \\
${ }^{12}$ & 0.42 & $\geq 0$ & 156 & 106 & $\mathbf{4 5}$ & 50 & $\mathbf{2 1}$ & $\mathbf{6 6}$ \\
${ }^{13}$ [6] & 0.20 & $\geq 0$ & 1 & 1 & $\mathbf{0}$ & 0 & $\mathbf{0}$ & $\mathbf{0}$ \\
V90-V94 & 0.20 & $\geq 0$ & 3 & 3 & $\mathbf{1}$ & 0 & $\mathbf{0}$ & $\mathbf{1}$ \\
& & & & & & & & \\
X60-X84.9,Y87.0 & 0.28 & $\geq 15$ & 185 & 150 & $\mathbf{4 2}$ & 35 & $\mathbf{1 0}$ & $\mathbf{5 2}$ \\
X85-Y09,Y87.1 & 0.46 & $\geq 15$ & 23 & 15 & $\mathbf{7}$ & 8 & $\mathbf{4}$ & $\mathbf{1 1}$ \\
& & & 2261 & 1277 & $\mathbf{3 5 9}$ & 984 & $\mathbf{1 8 3}$ & $\mathbf{5 4 2}$ \\
\hline
\end{tabular}

\section{Intentional Injuries}

Suicide
Homicide

Total

Sources: Maine Department of Health and Human Services, Office of Data, Research and Vital Statistics, 20 1277

revision, Clinical Modification (ICD-10-CM); Bouchery et. al., 2010; Wickizer, 1999; NIDA/NIAAA, 1998

* ARD - Alcohol Related Deaths

\footnotetext{
${ }^{11} \mathrm{X} 31, \mathrm{~W} 78, \mathrm{~W} 79$, W50, W51, W22-W24, W27-W34, Y10, Y13, Y14, Y18, Y19

${ }^{12}$ V02-V04, V09 (.0, .2), V12-V14 (.3-.9), V19 (.0-.2, .4-.6), V20-V79, V80 (.3-.5), V81 (.0, .1), V82 (.0, .1), V83-V86, V87 (.0-.8), V88 (.0-.8), V89 (.0, .2)

${ }^{13}$ V01, V06, V09 (.1, .3, .9), V10-V11, V12-V14 (.0-.2), V16-V18, V19 (.3, .8, .9), V82 (.2-.9), V87.9, V88.9, V89 (.1, .3)
} 
Table 4.3

Deaths attributable to drugs

Maine, 2010

\begin{tabular}{|c|c|c|c|c|c|c|c|c|c|}
\hline \multirow[b]{2}{*}{ Diagnosis } & \multirow{2}{*}{$\begin{array}{l}\text { ICD-10-CM } \\
\text { Diagnostic } \\
\text { Code }\end{array}$} & \multirow[t]{2}{*}{ DAF } & \multirow{2}{*}{$\begin{array}{c}\text { Age } \\
\text { (Years) }\end{array}$} & \multirow{2}{*}{$\begin{array}{c}\text { Total } \\
\text { Deaths }\end{array}$} & \multicolumn{2}{|c|}{ Male } & \multicolumn{2}{|c|}{ Female } & \multirow{2}{*}{$\begin{array}{l}\text { Total } \\
\text { Drug } \\
\text { Related } \\
\text { Deaths }\end{array}$} \\
\hline & & & & & $\begin{array}{l}\text { Total } \\
\text { Deaths }\end{array}$ & $\begin{array}{l}\text { Drug } \\
\text { Related } \\
\text { Deaths }\end{array}$ & $\begin{array}{l}\text { Total } \\
\text { Deaths }\end{array}$ & $\begin{array}{l}\text { Drug } \\
\text { Related } \\
\text { Deaths }\end{array}$ & \\
\hline \multicolumn{10}{|l|}{ Direct Causes } \\
\hline Drug Dependence & $\mathrm{F} 11-\mathrm{F} 19(.2)$ & 1 & $\geq 0$ & 2 & 0 & 0 & 2 & 2 & 2 \\
\hline Nondependent abuse of drugs & F11-F19(.1) & 1 & $\geq 0$ & 2 & 0 & 0 & 2 & 2 & 2 \\
\hline Accidental poisoning by drugs* & & 1 & $\geq 0$ & 128 & 76 & 76 & 52 & 52 & 128 \\
\hline Poisoning by drugs undetermined intent* & & 1 & $\geq 0$ & 8 & 4 & 4 & 4 & 4 & 8 \\
\hline Self-inflicted drug poisoning* & & 1 & $\geq 0$ & 31 & 19 & 19 & 12 & 12 & 31 \\
\hline \multicolumn{10}{|l|}{ Indirect Causes } \\
\hline HIV/AIDS & B20-B24 & 0.05 & $\geq 0$ & 9 & 8 & 0 & 1 & 0 & $\mathbf{0}$ \\
\hline Hepatitis B & B16.9 & 0.28 & $\geq 0$ & 2 & 2 & 1 & 0 & 0 & 1 \\
\hline Homicide* & X85-Y09,Y87.1 & 0.13 & $\geq 15$ & 25 & 17 & 2 & 8 & 1 & 3 \\
\hline Total & & & & 97 & 64 & 102 & 81 & 73 & 175 \\
\hline
\end{tabular}

Sources: Maine Department of Health and Human Services, Office of Data, Research and Vital Statistics, 2012; *Maine Office of the Chief Medical Examiiner, 2013; International Classification of Diseases, $10^{\text {th }}$ revision, Clinical Modification (ICD-10-CM); Wickizer, 1999; NIDA/NIAAA, 1998 
Table 4.4a

Estimated mortality costs

\begin{tabular}{|c|c|c|c|c|c|c|c|c|c|}
\hline & & $\begin{array}{c}\text { ARD } \\
\text { deaths }\end{array}$ & $\begin{array}{c}\text { NPV } \\
\text { Future } \\
\text { Earning }\end{array}$ & $\begin{array}{c}\text { ALC } \\
\text { Total costs } \\
\text { Before income } \\
\text { discount }\end{array}$ & $\begin{array}{c}\text { DRD } \\
\text { deaths }\end{array}$ & $\begin{array}{c}\text { NPV } \\
\text { Future } \\
\text { Earning }\end{array}$ & $\begin{array}{c}\text { DRUG } \\
\text { Total costs } \\
\text { Before income } \\
\text { discount }\end{array}$ & $\begin{array}{l}\text { ME/National } \\
\text { per cap inc. }\end{array}$ & $\begin{array}{l}\text { Total } \\
\text { Loss }\end{array}$ \\
\hline \multirow[t]{7}{*}{ Male* } & $1-18$ & 10 & $\$ 1,659,719$ & $\$ 16,597,189$ & 0 & $\$ 1,659,719$ & $\$$ & 0.9383 & $\$ 15,573,143$ \\
\hline & $19-24$ & 14 & $\$ 1,921,027$ & $\$ 26,894,371$ & 11 & $\$ 1,921,027$ & $\$ 21,131,292$ & 0.9383 & $\$ 45,062,479$ \\
\hline & $25-34$ & 16 & $\$ 1,797,244$ & $\$ 28,755,898$ & 18 & $\$ 1,797,244$ & $\$ 32,350,385$ & 0.9383 & $\$ 57,336,026$ \\
\hline & $35-44$ & 12 & $\$ 1,500,876$ & $\$ 18,010,517$ & 24 & $\$ 1,500,876$ & $\$ 36,021,034$ & 0.9383 & $\$ 50,697,804$ \\
\hline & $45-54$ & 65 & $\$ 980,606$ & $\$ 63,739,365$ & 32 & $\$ 980,606$ & $\$ 31,379,380$ & 0.9383 & $\$ 89,249,919$ \\
\hline & $55-64$ & 82 & $\$ 425,099$ & $\$ 34,858,152$ & 9 & $\$ 425,099$ & $\$ 3,825,895$ & 0.9383 & $\$ 36,297,241$ \\
\hline & $65+$ & 157 & $\$ 111,117$ & $\$ 17,445,330$ & 5 & $\$ 111,117$ & $\$ 555,584$ & 0.9383 & $\$ 16,890,257$ \\
\hline $\begin{array}{l}\text { Total } \\
\text { Males }\end{array}$ & & & & $\$ 206,300,822$ & & & $\$ 125,263,570$ & .9383 & $\$ 311,106,868$ \\
\hline \multirow[t]{7}{*}{ Female* } & $1-18$ & 3 & $\$ 1,226,949$ & $\$ 3,680,846$ & 1 & $\$ 1,226,949$ & $\$ 1,226,949$ & 0.9383 & $\$ 4,604,984$ \\
\hline & $19-24$ & 5 & $\$ 1,374,168$ & $\$ 6,870,841$ & 5 & $\$ 1,374,168$ & $\$ 6,870,841$ & 0.9383 & $\$ 12,893,820$ \\
\hline & $25-34$ & 4 & $\$ 1,260,684$ & $\$ 5,042,736$ & 10 & $\$ 1,260,684$ & $\$ 12,606,841$ & 0.9383 & $\$ 16,560,598$ \\
\hline & $35-44$ & 9 & $\$ 967,656$ & $\$ 8,708,908$ & 21 & $\$ 967,656$ & $\$ 20,320,785$ & 0.9383 & $\$ 27,238,561$ \\
\hline & $45-54$ & 23 & $\$ 594,882$ & $\$ 13,682,285$ & 19 & $\$ 594,882$ & $\$ 11,302,757$ & 0.9383 & $\$ 23,443,466$ \\
\hline & $55-64$ & 35 & $\$ 235,570$ & $\$ 8,244,933$ & 9 & $\$ 235,570$ & $\$ 2,120,126$ & 0.9383 & $\$ 9,725,534$ \\
\hline & $65+$ & 103 & $\$ 40,910$ & $\$ 4,213,750$ & 3 & $\$ 40,910$ & $\$ 122,731$ & 0.9383 & $\$ 4,068,919$ \\
\hline $\begin{array}{c}\text { Total } \\
\text { Females }\end{array}$ & & & & $\$ 50,444,299$ & & & $\$ 54,571,030$ & .9383 & $\$ 998,535,881$ \\
\hline TOTAL & & & & $\$ 256,745,121$ & & & $\$ 179,834,600$ & & $\$ 409,642,749$ \\
\hline
\end{tabular}

Source: The Lewin Group (2010); Max, D. et. al. (2004); Maine Department of Health and Human Services, Office of Data, Research and Vital Statistics,

2012

Excluded from above, 6 males and 6 female due to unknown age

NPV is the Net Present Value based upon national rates. 
Table 4.4b

Estimated Years of Potential Life Lost (YPLL)

\begin{tabular}{lcrr}
\hline & & \multicolumn{1}{c}{$\begin{array}{c}\text { ALC } \\
\text { YPLL }\end{array}$} & \multicolumn{1}{c}{$\begin{array}{c}\text { DRUG } \\
\text { YPLL }\end{array}$} \\
\hline Male* & $1-18$ & 660 & 0 \\
& $19-24$ & 756 & 594 \\
& $25-34$ & 736 & 828 \\
& $35-44$ & 432 & 864 \\
& $45-54$ & 1,690 & 832 \\
& $55-64$ & 1,312 & 144 \\
& $65+$ & 864 & 28 \\
Total males & & $\mathbf{6 , 4 5 0}$ & $\mathbf{3 , 2 9 0}$ \\
& & & \\
Female* & $1-18$ & 213 & 71 \\
& $19-24$ & 295 & 295 \\
& $25-34$ & 204 & 510 \\
& $35-44$ & 369 & 861 \\
& $45-54$ & 713 & 589 \\
& $55-64$ & 735 & 189 \\
& $65+$ & 1,082 & 32 \\
\hline $\begin{array}{c}\text { Total } \\
\text { females }\end{array}$ & & $\mathbf{3 , 6 1 1}$ & $\mathbf{2 , 5 4 7}$ \\
\hline TOTAL & & $\mathbf{1 0 , 0 6 1}$ & $\mathbf{5 , 8 3 7}$ \\
(\%) & & $\mathbf{( 6 3 . 3 \% )}$ & $\mathbf{( 3 6 . 7 \% )}$ \\
\hline $\begin{array}{l}\text { Excluded from above, } 6 \text { males and 6 females due to } \\
\text { unknown age }\end{array}$ & & & \\
& & &
\end{tabular}




\section{Chapter 5}

\section{Crime}

Research and data collected for over two decades have shown a strong link between drug and alcohol abuse and its impact on crime. Although the exact nature and strength of the relationship with each type of crime is not fully known, there is little doubt that substance abuse increases the likelihood that certain crimes will be committed. A 1989 Department of Justice study found that in some cities as many as $50 \%-80 \%$ of persons arrested for felonies tested positive for drugs (Tonry \& Wilson, 1990). Recent surveys of incarcerated populations provide further evidence of the strong link between crime and the use of drugs and alcohol. In 2004, approximately one in four federal inmates (26\%) and one in three state inmates (32\%) reported that they were under the influence of alcohol or illicit drugs at the time of their current offense (U.S. Department of Justice, 2007). In 2010, the Office of National Drug Control Policy conducted urinalysis testing of male arrestees across ten urban sites nationally, finding that presence of at least one test substance ranged from 52\% in Washington, DC to $83 \%$ in Chicago; in addition, a low of $11 \%$ of arrestees in Washington, DC to 38\% in Sacramento tested positive for the presence of multiple substances. (ONDCP, 2011).

This chapter analyzes crime costs for Maine in 2010. It examines five types of costs related to criminal activity: (1) Law enforcement, (2) Judicial, (3) Correctional, and (4) Other societal costs.

\section{The major findings of the analysis were:}

- Of 19 arrests for homicide, an estimated 6 were related to alcohol and 3 to drug abuse.

- In 2010 there were 7,083 assault (aggravated, sexual and other) related arrests, of which an estimated 2,120 were related to alcohol abuse and 345 to drug abuse.

- Total estimated drug- and alcohol-related crime costs in 2010 were \$343.4 million.

- Of the four major crime cost categories analyzed, law enforcement costs were highest (\$119.7 million), followed by the cost of corrections (\$111.0 million). 


\section{Methodology}

Information was gathered from various sources on different criminal activities (offenses and arrests), corrections populations, numbers of crime victims, and property destruction. The variables were then adjusted to reflect criminal activity related specifically to drug and alcohol abuse.

The analysis was restricted to the set of crimes believed to be most closely linked to substance abuse (NIDA/NIAAA, 1998). They included the following Part I felonies:

- homicide

- assault (aggravated, sexual and other)

- robbery

- burglary

- larceny (property theft)

- auto theft

Less serious Part II offenses analyzed included:

- operating under the influence (OUI)

- liquor law violations

- public drunkenness

- stolen property (buying, receiving and selling)

- prostitution

- drug law violations (possession, sale, use, or manufacture).

The numbers of drug- and alcohol-related crimes were estimated by multiplying crime figures by attributable fractions in the same manner as done to derive other cost estimates. The attributable fractions used for this report were those used by NIDA/NIAAA (1998; Table C.1) and represent the most current evidence available regarding drug- and alcohol-related crime. The attributable fractions ranged from $5.1 \%$ for drug-related sexual assault to $100 \%$ for OUI. In other words, it was assumed that $5.1 \%$ of all sexual assaults are related to drug use; by definition, $100 \%$ of OUI offenses are related to alcohol use.

The attributable fractions used for tables 5.1-5.5 analyses are the same as were used in the 2005 report, which allows for consistency and comparison between the types of crimes and between the 2005 and 2010 reports. Table 5.1 shows the fractions used (crimes such as OUI with attributable fractions of $100 \%$ are not shown): 
Table 5.1 Attributable fractions

\begin{tabular}{lcc}
\hline & Alcohol & Drugs \\
\hline & $\mathbf{( \% )}$ & $\mathbf{( \% )}$ \\
Homicide & 30.0 & 15.8 \\
Aggravated Assault & 30.0 & 5.1 \\
Sexual Assault & 22.5 & 5.1 \\
Other Assault & 30.0 & 5.1 \\
Robbery & 3.4 & 27.2 \\
Burglary & 3.6 & 30.0 \\
Larceny & 2.8 & 29.6 \\
Auto Theft & 3.5 & 6.8 \\
Stolen Property & 0.0 & 15.1 \\
Prostitution & 0.0 & 12.8 \\
\hline
\end{tabular}

To derive some of the cost estimates (judicial costs), it was necessary to convert numbers of arrests or offenses into dollar equivalents. This conversion was done using the same procedure as Rice et al. (1990), which assumed that costs were proportional to the numbers of crimes committed.

\section{Results}

\section{Law Enforcement Costs}

Police Protection:

Police protection costs were estimated based on the 33,020 arrests (Maine DPS, 2010) for Part I and II offenses committed in 2010 (Table 5.2). The numbers of the offenses were multiplied by the above attributable fractions to obtain estimates of the number of drug- and alcohol-related offenses committed. In 2010 the police protection costs for alcohol- and drugrelated crimes were estimated at $\$ 47.7$ million (Table 5.2). Based on 2005 Cost Report data (OSA, 2007) and adjusted for inflation (InflationData.com, 2012; US Department of Justice, 2007), cost per arrest is estimated at $\$ 4,082$. For OUI, liquor law offenses, and public drunkenness offenses, the arrest cost from Baird et al. (2004) was used and adjusted for inflation, for a total of $\$ 50.64$ (the cost per arrest for those offenses in 2005 was $\$ 45.63$ and in 2000 was \$39.14).

There were an estimated 6 homicides and 2,120 assaults in 2010 related to alcohol use or abuse. There were fewer drug-related crimes in these two categories, 3 and 345, respectively, but levels of drug-related robberies, burglaries and thefts were substantially higher compared to alcohol-related robberies, burglaries and thefts. 


\subsection{Estimated cost of police protection}

Maine, 2010

\begin{tabular}{|c|c|c|c|c|c|c|c|c|c|}
\hline \multirow[t]{2}{*}{ Type of offense } & \multirow[t]{2}{*}{$\begin{array}{c}\text { Total } \\
\text { arrests }\end{array}$} & \multicolumn{2}{|c|}{$\begin{array}{l}\text { Attributable } \\
\text { Fraction }\end{array}$} & \multicolumn{2}{|c|}{$\begin{array}{c}\text { Number of arrests } \\
\text { due to: }\end{array}$} & \multirow[t]{2}{*}{$\begin{array}{l}\text { Cost per } \\
\text { arrest }\end{array}$} & \multicolumn{3}{|c|}{ Police protection costs } \\
\hline & & Alcohol & Drugs & Alcohol & Drugs & & Alcohol & Drug & Total \\
\hline Homicide & 19 & .30 & .158 & 5.7 & 3 & $\$ 4,082.31$ & $\$ 23,269$ & $\$ 12,247$ & $\$ 35,516$ \\
\hline Aggravated assault & 610 & .30 & .024 & 183 & 14.64 & $\$ 4,082.31$ & $\$ 747,063$ & $\$ 59,765$ & $\$ 806,828$ \\
\hline Sexual assault & 68 & .225 & .051 & 15.3 & 3.47 & $\$ 4,082.31$ & $\$ 62,459$ & $\$ 14,166$ & $\$ 76,625$ \\
\hline Other assaults & 6,405 & .30 & .051 & 1921.5 & 326.66 & $\$ 4,082.31$ & $\$ 7,844,159$ & $\$ 1,333,527$ & $\$ 9,177,686$ \\
\hline Robbery & 191 & .034 & .272 & 6.5 & 51.95 & $\$ 4,082.31$ & $\$ 26,535$ & $\$ 212,076$ & $\$ 238,611$ \\
\hline Burglary & 1,440 & .036 & .30 & 51.84 & 432 & $\$ 4,082.31$ & $\$ 211,627$ & $\$ 1,763,558$ & $\$ 1,975,185$ \\
\hline Larceny-theft & 6,119 & .028 & .296 & 171.33 & 1811.22 & $\$ 4,082.31$ & $\$ 699,422$ & $\$ 7,393,962$ & $\$ 8,093,384$ \\
\hline Auto theft & 229 & .035 & .068 & 8 & 15.57 & $\$ 4,082.31$ & $\$ 32,658$ & $\$ 63,562$ & $\$ 96,220$ \\
\hline OUI & 6,245 & 1.00 & .0 & 6,245 & 0 & $\$ 50.64$ & $\$ 316,247$ & $\$ 0$ & $\$ 316,247$ \\
\hline Liquor laws & 4,950 & 1.00 & .0 & 4,950 & 0 & $\$ 50.64$ & $\$ 250,668$ & $\$ 0$ & $\$ 250,668$ \\
\hline Public drunkenness & 39 & 1.00 & .0 & 39 & 0 & $\$ 50.64$ & $\$ 1,975$ & $\$ 0$ & $\$ 1,975$ \\
\hline Stolen property & 211 & 0.00 & .151 & 0 & 31.86 & $\$ 4,082.31$ & $\$ 0$ & $\$ 130,062$ & $\$ 130,062$ \\
\hline Prostitution & 14 & 0.00 & .128 & 0 & 1.79 & $\$ 4,082.31$ & $\$ 0$ & $\$ 7,307$ & $\$ 7,307$ \\
\hline Drug laws & 6,479 & 0.00 & 1 & 0 & 6,479 & $\$ 4,082.31$ & $\$ 0$ & $\$ 26,449,286$ & $\$ 26,449,286$ \\
\hline TOTAL & 33,020 & & & & & & $\$ 10,216,082$ & $\$ 37,439,518$ & $\$ 47,655,600$ \\
\hline
\end{tabular}

Sources: Maine Department of Public Safety, 2010; Harwood et al., 1998; OSA, 2007 


\section{Drug Demand and Supply Control:}

Demand reduction refers to programs and research related to drug abuse treatment and prevention that are designed to reduce the demand for drugs. Supply reduction refers to a wide scope of law enforcement related activities designed to reduce the supply of drugs (this is often referred to as drug control). (National Drug Control Strategy, 2010)

Drug traffic control is a national priority involving a wide range of federal, state and local agencies. Because so many different agencies are involved in drug control it is difficult to accurately estimate the costs for Maine. National data on drug traffic control costs were used to compute the per capita costs for the relevant expenditure categories shown in Table 5.3 below. Per capita costs were applied to Maine. Total estimated drug control expenditures for Maine in 2010 were estimated at $\$ 64.7$ million.

Table 5.3

\section{Drug Control Expenditures}

Maine, 2010

\begin{tabular}{lc}
\hline Activity & Expenditures \\
\hline Demand reduction & $\$ 22,633,774$ \\
Supply reduction & $\$ 42,047,983$ \\
\hline TOTAL & $\mathbf{\$ 6 4 , 6 8 1 , 7 5 7}$ \\
\hline
\end{tabular}

Source: U.S. Department of Justice; National Drug Control Strategy, 2010.

The mandated duties of the Office of Substance Abuse and Mental Health Services include providing funds for the prevention and treatment of substance abuse disorders. The expenditures given in the Prevention category in Table 5.4 include only administrative and prevention expenditures that were incurred by the Office of Substance Abuse in 2010. The majority of the funds were granted out to community coalitions, schools, and prevention organizations. The largest portion (83\%) of the $\$ 7.3$ million prevention budget was federal grant money that provides funding to community coalitions so that they may develop and implement evidencebased prevention practices. 
Table 5.4

Substance Control Expenditures

Maine Office of Substance Abuse, 2010

\begin{tabular}{lrrr}
\hline Funding source & Total expenditures & \multicolumn{2}{c}{ Expenditures } \\
\hline Prevention - OSA & & Alcohol (50\%) & Drug (50\%) \\
$\quad$ State general fund & $\$ 577,461$ & $\$ 288,730$ & $\$ 288,730$ \\
$\quad$ Federal categorical & $\$ 3,304,764$ & $\$ 2,597,636$ & $\$ 707,128$ \\
$\quad$ Fund for Health Maine & $\$ 670,428$ & $\$ 335,214$ & $\$ 335,214$ \\
Safe and Drug Free Schools and Communities Act & $\$ 1,342,346$ & $\$ 671,173$ & $\$ 671,173$ \\
Substance Abuse Prevention and Treatment Block & & & \\
Grant & $\$ 1,441,946$ & $\mathbf{\$ 7 2 0 , 9 7 3}$ & $\mathbf{\$ 7 2 0 , 9 7 3}$ \\
\hline Total & $\mathbf{\$ 7 , 3 3 6 , 9 4 4}$ & $\mathbf{\$ 4 , 6 1 3 , 7 2 6}$ & $\mathbf{\$ 2 , 7 2 3 , 2 1 9}$ \\
\hline
\end{tabular}

\section{Judicial:}

Legal and judicial costs were estimated based on the number of arrests for Part I and II crimes (Table 5.5). The FBI lists the following as Part I crimes: homicide, forcible rape, robbery, aggravated assault, burglary, larceny, motor vehicle theft, and arson. Part II crime includes liquor offenses, simple assault, forgery, fraud, embezzlement, stolen property (buying, receiving, possessing), vandalism, weapons, prostitution, sex offenses, drug violations, gambling, alcohol violations, etc. Since only 2002 cost figures were available from the U.S. Bureau of Justice Statistics, these data were used and adjusted for inflation. In 2002, 54,800 arrests were made in Maine. Total legal and adjudication costs were estimated at $\$ 80.0$ million (U.S. Department of Justice, 2007). In 2002, the cost per arrest was estimated as $\$ 1,460.29$; after adjustment for inflation (.0768) it was $\$ 1,572.44$ in 2005. We further adjusted for inflation from 2005 to 2010 time frame using .1256. A final cost per arrest of $\$ 1,770$ was used for legal and adjudication costs in 2010.

The most costly Part I crime category was Other Assaults, \$4.0 million, due to the large number of alcohol- related arrests. The most costly Part II crime category was drug law violations, \$11.5 million. The total estimated 2010 cost for drug- and alcohol-related legal and adjudication activities was $\$ 21.0$ million, with drug abuse accounting for $77.4 \%$ of the costs. 
Table 5.5

Legal and adjudication costs 2010

\begin{tabular}{|c|c|c|c|c|c|c|c|c|c|}
\hline \multirow[t]{2}{*}{ Type of offense } & \multirow[t]{2}{*}{$\begin{array}{c}\text { Total } \\
\text { arrests }\end{array}$} & \multicolumn{2}{|c|}{$\begin{array}{c}\text { Attributable } \\
\text { Fraction }\end{array}$} & \multicolumn{2}{|c|}{$\begin{array}{l}\text { Number of } \\
\text { arrests due to: }\end{array}$} & \multirow{2}{*}{$\begin{array}{c}\text { Cost } \\
\text { per } \\
\text { arrest }\end{array}$} & \multicolumn{3}{|c|}{ Legal and adjudication costs } \\
\hline & & Alcohol & Drugs & Alcohol & Drugs & & Alcohol & Drug & Total \\
\hline Homicide & 19 & 0.3 & 0.158 & 5.7 & 3 & $\$ 1,770$ & $\$ 10,089$ & $\$ 5,310$ & $\$ 15,399$ \\
\hline Aggravated assault & 610 & 0.3 & 0.024 & 183 & 14.64 & $\$ 1,770$ & $\$ 323,910$ & $\$ 25,913$ & $\$ 349,823$ \\
\hline Sexual assault & 68 & 0.225 & 0.051 & 15.3 & 3.47 & $\$ 1,770$ & $\$ 27,081$ & $\$ 6,142$ & $\$ 33,223$ \\
\hline Other assaults & 6,406 & 0.3 & 0.051 & 1921.5 & 326.66 & $\$ 1,770$ & $\$ 3,401,055$ & $\$ 578,188$ & $\$ 3,979,243$ \\
\hline Robbery & 191 & 0.034 & 0.272 & 6.5 & 51.95 & $\$ 1,770$ & $\$ 11,505$ & $\$ 91,952$ & $\$ 103,457$ \\
\hline Burglary & 1,440 & 0.036 & 0.3 & 51.84 & 432 & $\$ 1,770$ & $\$ 91,757$ & $\$ 764,640$ & $\$ 856,397$ \\
\hline Larceny-theft & 6,119 & 0.028 & 0.296 & 171.33 & 1811.22 & $\$ 1,770$ & $\$ 303,254$ & $\$ 3,205,859$ & $\$ 3,509,114$ \\
\hline Auto theft & 229 & 0.035 & 0.068 & 8 & 15.57 & $\$ 1,770$ & $\$ 14,160$ & $\$ 27,559$ & $\$ 41,719$ \\
\hline OUI & 6,245 & 1 & 0 & 6,245 & 0 & $\$ 51$ & $\$ 315,373$ & $\$ 0$ & $\$ 315,373$ \\
\hline Liquor laws & 4,950 & 1 & 0 & 4,950 & 0 & $\$ 51$ & $\$ 249,975$ & $\$ 0$ & $\$ 249,975$ \\
\hline Public drunkenness & 39 & 1 & 0 & 39 & 0 & $\$ 51$ & $\$ 1,970$ & $\$ 0$ & $\$ 1,970$ \\
\hline Stolen property & 211 & 0 & 0.151 & 0 & 31.86 & $\$ 1,770$ & $\$ 0$ & $\$ 56,392$ & $\$ 56,392$ \\
\hline Prostitution & 14 & 0 & 0.128 & 0 & 1.79 & $\$ 1,770$ & $\$ 0$ & $\$ 3,168$ & $\$ 3,168$ \\
\hline Drug laws & 6,479 & 0 & 1 & 0 & 6,479 & $\$ 1,770$ & $\$ 0$ & $\$ 11,467,830$ & $\$ 11,467,830$ \\
\hline TOTAL & 33,020 & & & & & & $\$ 4,750,128$ & $\$ 16,232,953$ & $\$ 20,983,081$ \\
\hline
\end{tabular}

Sources: Wickizer, 1999; Maine Department of Public Safety, 2010; OSA, 2007 (US DOJ (2007); Harwood et al, 1998 ; Rice et al., 1990 


\section{Corrections}

State Corrections:

Total state substance abuse related corrections costs were estimated at $\$ 68.4$ million (Table 5.6). This is 2.4 times higher than it was in 2005. The average annual estimated cost per inmate in 2010 was \$46,404 (Vera Institute of Justice, 2012). This includes funds spent on capital and state wide administration. Incarcerations related to drugs accounts for $59.8 \%$ of total costs, equaling \$40.9 million.

The Maine Department of Corrections provided the number of state correctional inmates imprisoned for each offense in 2010. Table 5.6 uses attribution fractions from The Lewin Group, Inc. (2010) and the National Drug Intelligence Center (2011) to estimate the proportion of offenses attributable to alcohol or drug use. These are different than the ones used for the other crime data, but these are thought to be a more accurate representation of those who are incarcerated. The number of alcohol and drug related offenses were then multiplied by the average annual cost per inmate of \$46,404 (Vera Institute of Justice, 2012). As Table 5.6 shows, the most costly offender category was drug law violations ( $\$ 14.2$ million) followed by homicide (\$10.7 million) and burglary (\$9.4 million). 
Table 5.6

Estimated cost of state corrections, Maine, 2010

\begin{tabular}{|c|c|c|c|c|c|c|c|c|}
\hline \multirow[t]{2}{*}{ Offense } & \multirow[t]{2}{*}{$\begin{array}{c}\text { Total } \\
\text { Inmates }\end{array}$} & \multicolumn{2}{|c|}{ Attributable fraction } & \multicolumn{2}{|c|}{$\begin{array}{c}\begin{array}{c}\text { Substance related } \\
\text { crimes }\end{array} \\
\end{array}$} & \multicolumn{3}{|c|}{ State corrections costs } \\
\hline & & Alcohol $^{1}$ & Drugs $^{2}$ & Alcohol & Drugs & Alcohol & Drugs & Total \\
\hline Homicide & 307 & 0.47 & 0.28 & 144 & 86 & $\$ 6,695,633$ & $\$ 3,988,888$ & $\$ 10,684,521$ \\
\hline Aggravated assault & 125 & 0.294 & 0.25 & 37 & 31 & $\$ 1,705,347$ & $\$ 1,450,125$ & $\$ 3,155,472$ \\
\hline Sexual assault & 237 & 0.283 & 0.18 & 67 & 43 & $\$ 3,112,363$ & $\$ 1,979,595$ & $\$ 5,091,957$ \\
\hline Other assault & 91 & 0.188 & 0.22 & 17 & 20 & $\$ 793,880$ & $\$ 929,008$ & $\$ 1,722,888$ \\
\hline Robbery & 216 & 0.265 & 0.46 & 57 & 99 & $\$ 2,656,165$ & $\$ 4,610,701$ & $\$ 7,266,866$ \\
\hline Burglary & 270 & 0.272 & 0.48 & 73 & 130 & $\$ 3,407,910$ & $\$ 6,013,958$ & $\$ 9,421,868$ \\
\hline Larceny-theft & 199 & 0.199 & 0.49 & 40 & 98 & $\$ 1,837,645$ & $\$ 4,524,854$ & $\$ 6,362,499$ \\
\hline Motor vehicle theft & 5 & 0.222 & 0.42 & 1 & 2 & $\$ 51,508$ & $\$ 97,448$ & $\$ 148,957$ \\
\hline Arson & 41 & & 0.29 & 0 & 12 & $\$ \quad-$ & $\$ 551,744$ & $\$ 551,744$ \\
\hline Vandalism & 0 & 0.268 & 0.25 & 0 & 0 & $\$$ & $\$ \quad-$ & $\$ \quad-$ \\
\hline Drug laws & 307 & 0 & 1 & 0 & 307 & $\$$ & $\$ 14,246,028$ & $\$ 14,246,028$ \\
\hline Liquor laws & 1 & 1 & 0 & 1 & 0 & $\$ 46,404$ & $\$ \quad-$ & $\$ 46,404$ \\
\hline Public Drunkeness & 0 & 1 & 0 & 0 & 0 & $\$ \quad-$ & $\$$ & $\$ \quad-$ \\
\hline OUI & 129 & 0.907 & 0.09 & 117 & 12 & $\$ 5,429,407$ & $\$ 538,750$ & $\$ 5,968,158$ \\
\hline Prostitution & 0 & & 0.25 & 0 & 0 & $\$ \quad-$ & $\$ \quad-$ & $\$$ \\
\hline Sex Offenses & 51 & 0.215 & 0.13 & 11 & 7 & $\$ 508,820$ & $\$ 307,659$ & $\$ 816,478$ \\
\hline Other & 166 & 0.159 & 0.22 & 26 & 37 & $\$ 1,224,787$ & $\$ 1,694,674$ & $\$ 2,919,461$ \\
\hline TOTAL & 2145 & & & & & $\$ 27,469,869$ & $\$ 40,933,432$ & $\$ 68,403,301$ \\
\hline
\end{tabular}

Sources: Maine Department of Corrections, 2012;

${ }^{1}$ Lewin Group, Inc. 2010. Economic Costs of Excessive Alcohol Consumption in the United States, 2006.

${ }^{2} 2011$ The Economic Impact of Illicit Drug Use on American Society. Washington D.C.: US Department of Justice. 


\section{County Corrections:}

In Maine, some individuals arrested for alcohol- and drug-related crimes are booked into county jails. Thus, some of the expense of operating these jails should be included in the analysis as drug- and alcohol-related costs. No one source captures all county jail costs. Some counties do not keep electronic records on reason for incarceration; therefore multiple contacts had to be made to estimate the number of persons in county jails for the entire state and the average annual cost per inmate. So to help estimate the total for 2010 the following information was collected: the average daily census in 4 of the county jails was 875 (Cumberland, Kennebec, Lincolns 2 bridges, and Somerset). Because these are thought to contain approximately half of Maine's County Inmate population, this number was doubled to get the estimated average daily county inmate population for the State.The U.S. Department of Justice, Office of Justice Programs, Bureau of Justice Statistics conducts an annual survey of state jails. In the 2011 survey the estimated number of jail inmates was 1,750. We were also provided actual number of offenses booked by Cumberland County Corrections. In Table 5.7, to get proportion of offenses we used the actual number of offenses booked (not people) to determine an estimated proportion by general category and applied that ratio to the average number of inmates in all Maine county jails per day in 2010. The average cost per Cumberland County inmate in 2011 was $\$ 130 /$ day or $\$ 47,450$ year. To adjust this to 2010 rates, we deducted 3.16\% which was the 2011 rate of inflation per inflationdata.com. After deducting the rate of inflation, the annual cost per inmate used was $\$ 45,951$.

In 2010, there were an estimated 9,463 incarcerated in Maine County jails. Total alcohol- and drug-related county corrections costs for 2010 are estimated at $\$ 42.6$ million. In $200566 \%$ of costs were due to alcohol related arrests; in 2010 this decreased to $49.8 \%$ of costs. The cost of drug related arrests, \$21.4 million, inched past that of alcohol related arrest costs, $\$ 21.3$ million. 
Table 5.7

Estimated cost of county corrections Maine, 2010

\begin{tabular}{|c|c|c|c|c|c|c|c|c|c|c|}
\hline \multirow[b]{2}{*}{ CC Offense } & \multirow[t]{2}{*}{$\begin{array}{l}\text { Est. } \\
\text { count }\end{array}$} & \multirow[t]{2}{*}{$\begin{array}{l}\text { Prop. of } \\
\text { total CC }\end{array}$} & \multirow{2}{*}{$\begin{array}{l}\text { Avg. \# } \\
\text { all } \\
\text { county } \\
\text { inmates }\end{array}$} & \multicolumn{2}{|c|}{$\begin{array}{l}\text { Attributable } \\
\text { Fraction }\end{array}$} & \multicolumn{2}{|c|}{$\begin{array}{l}\text { No. Inmate } \\
\text { Attributed } \\
\text { Substance Use }\end{array}$} & \multicolumn{3}{|c|}{ Cost attributable Substance Use } \\
\hline & & & & Alcohol & Drug & Alcohol & Drug & Alcohol & Drug & Total \\
\hline OUI & 927 & 0.0980 & 171 & 1 & 0.12 & 171.4 & 21 & $\$ 7,877,418$ & $\$ 945,290$ & $\$ 8,822,709$ \\
\hline Drug Laws & 796 & 0.0841 & 147 & 0 & 1 & 0.0 & 147 & $\$ 0$ & $\$ 6,764,213$ & $\$ 6,764,213$ \\
\hline Arson & 6 & 0.0006 & 1 & 0.05 & 0.13 & 0.1 & 0.1 & $\$ 2,549$ & $\$ 6,628$ & $\$ 9,178$ \\
\hline Liquor laws & 270 & 0.0285 & 50 & 1 & 0 & 49.9 & 0.0 & $\$ 2,294,394$ & $\$ 0$ & $\$ 2,294,394$ \\
\hline Burglary & 259 & 0.0274 & 48 & 0.272 & 0.45 & 13.0 & 22 & $\$ 598,650$ & $\$ 990,413$ & $\$ 1,589,063$ \\
\hline Stolen Prop. & 77 & 0.0081 & 14 & 0.199 & 0.25 & 2.8 & 4 & $\$ 130,211$ & $\$ 163,582$ & $\$ 293,793$ \\
\hline Theft & 842 & 0.0890 & 156 & 0.199 & 0.39 & 31.0 & 61 & $\$ 1,423,867$ & $\$ 2,790,493$ & $\$ 4,214,359$ \\
\hline Robbery & 56 & 0.0059 & 10 & 0.265 & 0.51 & 2.7 & 5 & $\$ 126,107$ & $\$ 242,696$ & $\$ 368,803$ \\
\hline Homicide & 11 & 0.0012 & 2 & 0.47 & 0.15 & 1.0 & 0.3 & $\$ 43,933$ & $\$ 14,021$ & $\$ 57,955$ \\
\hline Agg Assault/ & 53 & 0.0056 & 10 & 0.294 & 0.23 & 2.9 & 2 & $\$ 132,394$ & $\$ 103,574$ & $\$ 235,968$ \\
\hline Sex. Assault/abuse & 46 & 0.0049 & 9 & 0.283 & 0.2 & 2.4 & 2 & $\$ 110,624$ & $\$ 78,179$ & $\$ 188,803$ \\
\hline Other Assault & 988 & 0.1044 & 183 & 0.188 & 0.22 & 34.3 & 40 & $\$ 1,578,307$ & $\$ 1,846,954$ & $\$ 3,425,261$ \\
\hline Prostitution & 5 & 0.0005 & 1 & 0.21 & 0.73 & 0.2 & 0.7 & $\$ 8,923$ & $\$ 31,017$ & $\$ 39,939$ \\
\hline Sub Total & 4336 & & & & & 0.0 & & & & \\
\hline Other Offense & 5127 & 0.5418 & 948 & 0.159 & 0.17 & 150.8 & 161.2 & $\$ 6,927,310$ & $\$ 7,406,558$ & $\$ 14,333,868$ \\
\hline TOTAL & 9463 & & & & & & & $\$ 21,254,686$ & $\$ 21,383,618$ & $\$ 42,638,304$ \\
\hline
\end{tabular}




\section{Other Societal Costs:}

Other social costs arising from drug and alcohol abuse include the costs of lost productivity due to incarceration, the value of lost productivity due to criminal victimization, and the cost of property damage arising from substance abuse-related accidents.

Productivity Losses Due to Incarceration:

Inmates of state prisons and local jails are unable to participate in the economy as workers. This results in a substantial economic cost to society in the form of lost productivity. The cost estimates were based upon the numbers of individuals entering state prisons and local/county jails shown in the previous section. We assumed, as did Rice et al. (1990), that one year was served per offense even though that would tend to inflate the cost of Part II offenses. Since annual costs were calculated, the analysis was based upon a maximum of 12 months served, even though individuals served much longer for some crimes (e.g., homicide). Numbers of person years served related to alcohol and drug use match the number of inmates in the state and county system as included in Tables 5.6 and 5.7. Productivity losses were calculated based upon 2011 US Department of Labor, Bureau of Labor Standards showing Maine's median annual wage of $\$ 40,190$, this was then adjusted to 2010 rates using inflationdata.com. This produced an estimated 2010 median annual wage for Maine of $\$ 38,960$. No discount is being applied even though it is expected that those incarcerated are likely to earn less than the average. They are being treated as if there were no drug or alcohol abuse incarcerations (this approach was used in the 2011 US DOJ Economic Impact of Illicit Drug Use report as well).

The findings are presented in Table 5.8. Total productivity losses due to incarceration were estimated to be $\$ 81.5$ million, with $\$ 57.5$ million representing losses associated with incarceration in state prisons. Productivity losses were higher for drug-related productivity losses, \$46.3 million (56.8\%), than for alcohol-related productivity losses, \$35.2 million $(43.1 \%)$. 
Table 5.8

Estimated productivity losses due to incarceration, Maine, 2010

\begin{tabular}{|c|c|c|c|c|c|}
\hline \multirow[b]{2}{*}{ Offense } & \multicolumn{2}{|c|}{ Alcohol } & \multicolumn{2}{|c|}{ Drugs } & \multirow[t]{2}{*}{ Total losses } \\
\hline & $\begin{array}{c}\text { Person } \\
\text { years } \\
\text { served } \\
\end{array}$ & $\begin{array}{c}\text { Productivity } \\
\text { losses }\end{array}$ & $\begin{array}{c}\text { Person } \\
\text { years } \\
\text { served }\end{array}$ & $\begin{array}{c}\text { Productivity } \\
\text { losses }\end{array}$ & \\
\hline \multicolumn{6}{|l|}{ State prisons } \\
\hline Homicide & 144.0 & $\$ 5,610,240$ & 86.0 & $\$ 3,350,560$ & $\$ 8,960,800$ \\
\hline Assault & 121.0 & $\$ 4,714,160$ & 94.0 & $\$ 3,662,240$ & $\$ 8,376,400$ \\
\hline Robbery & 57.0 & $\$ 2,220,720$ & 99.0 & $\$ 3,857,040$ & $\$ 6,077,760$ \\
\hline Burglary & 73.0 & $\$ 2,844,080$ & 130.0 & $\$ 5,064,800$ & $\$ 7,908,880$ \\
\hline Auto theft & 1.0 & $\$ 38,960$ & 2.0 & $\$ 77,920$ & $\$ 116,880$ \\
\hline OUI & 117.0 & $\$ 4,558,320$ & 12.0 & $\$ 467,520$ & $\$ 5,025,840$ \\
\hline Larceny/theft & 40.0 & $\$ 1,558,400$ & 98.0 & $\$ 3,818,080$ & $\$ 5,376,480$ \\
\hline Drug laws & 0.0 & $\$ 0$ & 307.0 & $\$ 11,960,720$ & $\$ 11,960,720$ \\
\hline Arson & 0.0 & $\$ 0$ & 12.0 & $\$ 467,520$ & $\$ 467,520$ \\
\hline Liquor laws & 1.0 & $\$ 38,960$ & 0.0 & $\$ 0$ & $\$ 38,960$ \\
\hline Sex Offenses & 11.0 & $\$ 428,560$ & 7.0 & $\$ 272,720$ & $\$ 701,280$ \\
\hline Other & 26.0 & $\$ 1,012,960$ & 37.0 & $\$ 1,441,520$ & $\$ 2,454,480$ \\
\hline Total & 591.0 & $\$ 23,025,360$ & 884.0 & $\$ 34,440,640$ & $\$ 57,466,000$ \\
\hline \multicolumn{6}{|l|}{ County/Local jails } \\
\hline Homicide & 1.0 & $\$ 38,960$ & 0.3 & $\$ 11,688$ & $\$ 50,648$ \\
\hline Assault & 39.6 & $\$ 1,542,816$ & 44.0 & $\$ 1,714,240$ & $\$ 3,257,056$ \\
\hline Robbery & 2.7 & $\$ 105,192$ & 5.0 & $\$ 194,800$ & $\$ 299,992$ \\
\hline Burglary & 13.0 & $\$ 506,480$ & 22.0 & $\$ 857,120$ & $\$ 1,363,600$ \\
\hline Theft & 31.0 & $\$ 1,207,760$ & 61.0 & $\$ 2,376,560$ & $\$ 3,584,320$ \\
\hline OUI & 171.4 & $\$ 6,677,744$ & 21.0 & $\$ 818,160$ & $\$ 7,495,904$ \\
\hline Stolen property & 2.8 & $\$ 109,088$ & 4.0 & $\$ 155,840$ & $\$ 264,928$ \\
\hline Drug laws & 0.0 & $\$ 0$ & 147.0 & $\$ 5,727,120$ & $\$ 5,727,120$ \\
\hline Liquor laws & 49.9 & $\$ 1,944,104$ & 0.0 & $\$ 0$ & $\$ 1,944,104$ \\
\hline Arson & 0.1 & $\$ 3,896$ & 0.1 & $\$ 3,896$ & $\$ 7,792$ \\
\hline Prostitution & 0.2 & $\$ 7,792$ & 0.7 & $\$ 27,272$ & $\$ 35,064$ \\
\hline Total & 311.7 & $\$ 12,143,832$ & 305.1 & $\$ 11,886,696$ & $\$ 24,030,528$ \\
\hline Total state and local & 902.7 & $\$ 35,169,192$ & 1189.1 & $\$ 46,327,336$ & $\$ 81,496,528$ \\
\hline
\end{tabular}




\section{Property Destruction:}

State data on property destruction costs for 2010 were available from the Maine Department of Public Safety, Crime in Maine 2010 report. Estimate of property destruction costs attributable to alcohol and drug use were calculated using the drug and alcohol attributable fractions included in Table 5.1 earlier in this chapter. Overall, property destruction costs attributable to drug or alcohol use were estimated at $\$ 7.2$ million, with drug-related costs accounting for $\$ 6.4$ million (89.0\%).

Table 5.9

Property destruction due to crime, Maine, 2010

\begin{tabular}{|c|c|c|c|c|}
\hline Type of offense & $\begin{array}{c}\text { Property destruction } \\
\text { losses }\end{array}$ & Alcohol related losses & Drug related losses & Total losses \\
\hline Robbery & $\$ 439,414$ & $\$ 14,940$ & $\$ 119,521$ & $\$ 134,461$ \\
\hline Murder & $\$ 1,178$ & $\$ 353$ & $\$ 186$ & $\$ 540$ \\
\hline Larceny & $\$ 11,863,202$ & $\$ 332,170$ & $\$ 3,511,508$ & $\$ 3,843,677$ \\
\hline Burglary & $\$ 8,370,639$ & $\$ 301,343$ & $\$ 2,511,192$ & $\$ 2,812,535$ \\
\hline Motor vehicle theft & $\$ 4,283,407$ & $\$ 149,919$ & $\$ 291,272$ & $\$ 441,191$ \\
\hline TOTAL & $\$ 24,957,840$ & $\$ 798,725$ & $\$ 6,433,678$ & $\$ 7,232,403$ \\
\hline
\end{tabular}




\section{Criminal Victimization:}

The economic cost associated with criminal victimization is the value of lost productivity, including time lost from work and the cost of medical care that the victim requires. There were no state level data on the number of crime victims, so the number of Part I offenses were used for the analysis, based upon the assumption that there was one victim per offense. The average number of days lost from work was estimated in an earlier report by Liu (1992). The number of offenses was multiplied by the estimated monetary loss, based on lost workdays, and the product was then multiplied by the appropriate attributable fraction for the offense. The estimated cost of a work day loss was calculated by taking the median salary, using the rate estimated earlier in this chapter, $\$ 38,960$ for Maine by adjusting for inflation the rate from the 2005 cost report to and dividing by 260 work days (\$149.84/day). To calculate the loss of a work day for forcible rape, the median annual salary for women was used, $(\$ 34,965 / 260=\$ 134.48)$. The findings are shown in Table 5.10. As indicated, the total economic loss in 2010 due to criminal victimization related to drug and alcohol abuse was $\$ 3.0$ million, with drug abuse accounting for $85.0 \%$ of costs (\$2.5 million). 
Table 5.10

Estimated productivity losses for victims of crime, Maine, 2010

\begin{tabular}{|c|c|c|c|c|c|c|c|c|c|}
\hline Offense & $\begin{array}{c}\text { Number }^{14} \\
\text { of } \\
\text { offenses }\end{array}$ & $\begin{array}{l}\text { Average }^{15} \\
\text { work days }\end{array}$ & $\begin{array}{c}\text { Cost per } \\
\text { work } \\
\text { day }^{16} \\
\end{array}$ & Total & AAF & DAF & $\begin{array}{l}\text { Alcohol } \\
\text { losses }\end{array}$ & Drug losses & Total losses \\
\hline Forcible rape & 389 & 4.6 & $\$ 134.48$ & $\$ 240,639$ & 0.225 & 0.024 & $\$ 54,144$ & $\$ 5,775$ & $\$ 59,919$ \\
\hline $\begin{array}{l}\text { Aggravated } \\
\text { assault }\end{array}$ & 760 & 3.7 & $\$ 149.84$ & $\$ 421,350$ & 0.300 & 0.051 & $\$ 126,405$ & $\$ 21,489$ & $\$ 147,894$ \\
\hline Robbery & 416 & 4.4 & $\$ 149.84$ & $\$ 274,267$ & 0.034 & 0.272 & $\$ 9,325$ & $\$ 74,601$ & $\$ 83,926$ \\
\hline Burglary & 7,343 & 1.7 & $\$ 149.84$ & $\$ 1,870,468$ & 0.036 & 0.300 & $\$ 67,337$ & $\$ 561,140$ & $\$ 628,477$ \\
\hline Larceny & 24,490 & 1.7 & $\$ 149.84$ & $\$ 6,238,289$ & 0.028 & 0.296 & $\$ 174,672$ & $\$ 1,846,533$ & $\$ 2,021,206$ \\
\hline Motor vehicle & 985 & 2.7 & $\$ 149.84$ & $\$ 398,499$ & 0.035 & 0.068 & $\$ 13,947$ & $\$ 27,098$ & $\$ 41,045$ \\
\hline TOTAL & 34,383 & & & $\$ 9,443,512$ & & & $\$ 445,830$ & $\$ 2,536,637$ & $\$ 2,982,467$ \\
\hline
\end{tabular}

\footnotetext{
${ }^{14}$ Crime in Maine, 2010

${ }^{15}$ Liu, 1992

${ }^{16}$ Based on Median income
} 


\section{Summary}

Summary information is included in Table 5.11. With total costs estimated at \$343.4 million, criminal activity represents a major component of overall drug and alcohol-related costs, accounting for $24.9 \%$ of all statewide drug and alcohol costs. Within the crime category, subcategories with the greatest cost were law enforcement (\$119.7 million), followed closely by corrections (\$111.0 million).

Table 5.11

Summary of crime costs Maine, 2010

\begin{tabular}{|c|c|c|c|c|c|}
\hline Cost type & $\begin{array}{c}\begin{array}{c}\text { Cost } \\
\text { subtype }\end{array} \\
\end{array}$ & Total cost & $\begin{array}{c}\text { Percent of } \\
\text { total cost }\end{array}$ & $\begin{array}{c}\text { Alcohol } \\
\text { cost }\end{array}$ & $\begin{array}{c}\text { Drug } \\
\text { cost }\end{array}$ \\
\hline \multirow[t]{2}{*}{$\begin{array}{l}\text { Law } \\
\text { enforcement }\end{array}$} & $\begin{array}{l}\text { Police } \\
\text { protection }\end{array}$ & $\$ 47,655,600$ & $13.9 \%$ & $\$ 10,216,082$ & $\$ 37,439,518$ \\
\hline & $\begin{array}{l}\text { Drug } \\
\text { control }\end{array}$ & $\$ 72,018,701$ & $21.0 \%$ & $\$ 4,613,726$ & $\$ 67,404,976$ \\
\hline Judicial & & $\$ 20,983,081$ & $6.1 \%$ & $\$ 4,750,128$ & $\$ 16,232,953$ \\
\hline \multirow[t]{2}{*}{ Corrections } & State & $\$ 68,403,301$ & $19.9 \%$ & $\$ 27,469,869$ & $\$ 40,933,432$ \\
\hline & County & $\$ 42,638,303$ & $12.4 \%$ & $\$ 21,254,686$ & $\$ 21,383,618$ \\
\hline $\begin{array}{l}\text { Productivity } \\
\text { loss }\end{array}$ & & $\$ 81,496,528$ & $23.7 \%$ & $\$ 35,169,192$ & $\$ 46,327,336$ \\
\hline $\begin{array}{l}\text { Property } \\
\text { destruction }\end{array}$ & & $\$ 7,232,403$ & $2.1 \%$ & $\$ 798,725$ & $\$ 6,433,678$ \\
\hline Victimization & & $\$ 2,982,467$ & $0.9 \%$ & $\$ 445,830$ & $\$ 2,536,637$ \\
\hline TOTAL & & $\$ 343,410,384$ & $100.0 \%$ & $\$ 104,718,237$ & $\$ 238,692,148$ \\
\hline PERCENT & & & & $30.5 \%$ & $69.5 \%$ \\
\hline
\end{tabular}




\section{Chapter 6}

\section{Medical Care}

Alcohol or drug abuse may increase the risk of illness or injury and thereby increase the use of health care services. The effects of substance abuse on health care utilization may be obvious and immediate or more indirect and long term. The link between alcohol and drug use is clear in the case of an individual overdosing on drugs and then requiring hospitalization, or a drunk driver who sustains serious injury in an auto accident and requires emergency hospital treatment. But prolonged alcohol abuse can also increase the risk for a number of diseases, including stomach cancer, cancer of the esophagus, respiratory tuberculosis, diabetes, and hypertension, thereby increasing the demand for costly medical care as well as nursing home care.

This chapter analyzes 2010 medical costs for Maine related to drug and alcohol abuse. Four types of medical costs are reported: inpatient hospital costs, outpatient hospital costs, prescription drugs and non-durable medical supplies, and nursing home costs.

\section{The major findings of the analysis were:}

- There were approximately 6,453 hospital (inpatient) discharges in Maine in 2010 directly or indirectly related to drug and alcohol use or abuse.

- The total cost of providing hospital inpatient care for these patients, including adjustment for longer stays due to co-occurring substance dependency, was estimated at \$145.1 million, $83.4 \%$ of which was related to alcohol use.

- The estimated cost of outpatient medical care was $\$ 122.6$ million; $74.7 \%$ of those costs were alcohol related.

- Prescription drug costs and nursing home costs attributable to alcohol were, respectively, \$27.7 million and \$7.5 million.

- $\quad$ The total estimated medical cost was $\$ 302.8$ million. 


\section{Methodology}

The estimation of hospital inpatient and outpatient costs were based upon 2010 data from the Maine Health Data Organization (MHDO, 2013), which gathers information on total hospital charges, length of stay, diagnosis, gender and age for all hospital discharges in Maine. For this analysis, MHDO supplied data on patients discharged within selected diagnostic categories related to drug and alcohol abuse. These data were used to estimate inpatient hospital costs. The adjustment process used followed the same approach as used to estimate mortality costs (see Chapter 4) and is commonly known as the illness-specific approach (NIDA/NIAAA, 1998).

This illness-specific approach does not take into account the extra days a patient may stay in an inpatient hospital setting if he or she has a co-occurring alcohol or drug disorder. Estimating the costs of these extra days was not possible using the data obtained for this analysis, but it was possible to use cost estimates generated by the NIDA/NIAAA (1998) national study and extrapolate these costs to Maine. The NIDA/NIAAA study, which was based on analysis of over 200,000 records from the U.S. Hospital Discharge Survey, found that hospital inpatient costs associated with longer stays due to co-occurring alcohol or drug conditions represented $21.3 \%$ of substance abuse specific- and substance abuse related-costs. The Maine 2005 cost estimates derived from the analysis of inpatient discharge data were increased by this same percentage (21.3\%) to account for the longer hospital stays associated with secondary (cooccurring) diagnoses related to substance abuse. The 2010 cost report continues with this method.

The estimation of alcohol- and drug-related outpatient costs was also based upon data from the MHDO. The same approach was used to apply attributable fractions to these costs.

Cost estimates for prescription drugs in Maine came from data from the Kaiser Family Foundation (2013). As reported in NIDA/NIAAA (1998), the attributable fraction of $2.2 \%$ can be applied to prescription drugs used for the medical treatment of diseases and injuries related to substance abuse. This figure is based upon earlier research by Harwood et al. (1984), indicating that $2.2 \%$ of expenditures in this category can reasonably be attributed to alcohol abuse (no equivalent estimates have been made for drug abuse). Cost estimates for nursing home care also came from the Kaiser Family Foundation (2007). Based upon research from the 1985 National Nursing Home Survey (NIDA/NIAAA, 1998), it was assumed that $1.0 \%$ of all nursing home expenditures could reasonably be related to alcohol abuse. 


\section{Results}

As shown in Tables 6.1a and 6.1b, 6,453 inpatient hospital discharges occurred as a result of a medical condition or injury related to drug or alcohol abuse. Approximately 4,189 or 64.9\% of these were related to alcohol abuse. Males accounted for 3,941 discharges (61.1\%). Of the \$119.6 million in hospital inpatient costs for alcohol and drugs combined, shown in Table 6.1a and 6.1b, \$99.8 million (83.4\%) were for hospital care for an alcohol-related condition or injury. The major cost categories were: injuries and poisonings, alcohol psychoses and dependence, acute pancreatitis, drug psychoses and dependence, and cerebrovascular disease.

As discussed earlier, the $\$ 119.6$ million in hospital inpatient costs shown in Tables 6.1a and $6.1 \mathrm{~b}$ is based on data from the MHDO. These costs do not include incremental expenses associated with treating patients requiring longer hospitalization resulting from co-occurring alcohol or drug dependence. A 1998 NIDA/NIAAA report estimated these incremental costs at 21.3\% of direct alcohol- and drug-related hospital costs. To remain consistent with the 2005 cost report, the 2010 continued with this method. To account for these other indirect costs, the estimate of $\$ 119.6$ million should be multiplied by 1.213 , yielding a total cost estimate for alcohol- and drug-related hospital inpatient costs of \$145.1 million.

The estimation of alcohol- and drug-related outpatient costs was also based upon data from the MHDO. The same approach was used to apply attributable fractions to these costs. The total alcohol- and drug-related outpatient cost, as shown in Table 6.2 was \$122.6 million. Alcohol related costs represented $\$ 91.6$ million (74.7\%) of these outpatient costs.

Two other medical cost categories included here are prescription drug and nursing home costs. The estimates for these two categories are shown in Table 6.3. Of the over $\$ 2$ billion spent on these two categories it is estimated that $\$ 35.2$ million is due to alcohol abuse. For prescription drugs, the estimated cost was \$27.7 million. The estimated cost for nursing home care was $\$ 7.5$ million. Both of these cost categories are attributable to alcohol alone. 
Table 6.1a

Alcohol-related hospital inpatient direct costs, Maine 2010

\begin{tabular}{|c|c|c|c|c|c|c|c|c|c|c|c|}
\hline \multirow[b]{2}{*}{ Diagnosis or condition } & \multirow[b]{2}{*}{$\begin{array}{l}\text { ICD-9 } \\
\text { code }\end{array}$} & \multirow[b]{2}{*}{$\begin{array}{c}\text { Age } \\
\text { range }\end{array}$} & \multirow[b]{2}{*}{ AAF } & \multicolumn{2}{|c|}{$\begin{array}{c}\text { Est. number of alcohol- } \\
\text { related discharges }\end{array}$} & \multicolumn{6}{|c|}{ Estimated alcohol-related inpatient charges } \\
\hline & & & & Males & Females & & Male & & emale & & Total \\
\hline Alcoholic mental disorders \& psychoses & 291 & All & 1 & 1342 & 539 & & $10,027,053$ & & $3,558,079$ & $\$$ & $13,585,132$ \\
\hline Alcohol dependence syndrome & 303 & All & 1 & 698 & 277 & & $3,523,814$ & & $1,801,475$ & $\$$ & $5,325,289$ \\
\hline Non-dependent abuse of alcohol & 305 & All & 1 & 59 & 32 & $\$$ & 585,283 & $\$$ & 250,450 & $\$$ & 835,733 \\
\hline Alcoholic polyneuropathy & 357.5 & All & 1 & 0 & 1 & $\$$ & - & $\$$ & 30,954 & $\$$ & 30,954 \\
\hline Alcoholic gastritis & 535.3 & All & 1 & 2 & 1 & $\$$ & 25,571 & $\$$ & 16,316 & $\$$ & 41,887 \\
\hline Alcoholic fatty liver & 571 & All & 1 & 1 & 0 & $\$$ & 17,308 & $\$$ & - & $\$$ & 17,308 \\
\hline Acute alcoholic hepatitis & 571.1 & All & 1 & 16 & 9 & $\$$ & 327,857 & $\$$ & 346,564 & $\$$ & 674,421 \\
\hline Alcoholic cirrhosis of the liver & 571.2 & All & 1 & 22 & 6 & $\$$ & 403,543 & $\$$ & 224,766 & $\$$ & 628,309 \\
\hline Alcoholic liver damage, unspecified & 571.3 & All & 1 & 2 & 0 & $\$$ & 12,344 & $\$$ & - & $\$$ & 12,344 \\
\hline Toxic effect of alcohol & 980 & All & 1 & 90 & 96 & $\$$ & $1,852,943$ & & $1,489,444$ & $\$$ & $3,342,387$ \\
\hline Accidental poisoning by alcohol & E860.0-.1 & All & 1 & 3 & 1 & $\$$ & 40,414 & $\$$ & 21,873 & $\$$ & 62,287 \\
\hline Cancer of the lip, tongue, oral cavity, pharynx & 140-149 & $>=35$ & 0.5 & 11 & 4 & $\$$ & 155,323 & $\$$ & 106,566 & $\$$ & 261,889 \\
\hline Cancer of the esophagus & 150 & $>=35$ & 0.75 & 32 & 4 & $\$$ & $1,623,296$ & $\$$ & 122,630 & $\$$ & $1,745,927$ \\
\hline Cancer of the stomach & 151 & $>=35$ & 0.2 & 6 & 4 & $\$$ & 182,974 & $\$$ & 172,933 & $\$$ & 355,907 \\
\hline Cancer of the liver and intrahepatic bile ducts & $155.0-155.2$ & $>=35$ & 0.15 & 4 & 1 & $\$$ & 73,568 & $\$$ & 32,291 & $\$$ & 105,858 \\
\hline Cancer of the larynx & 161 & $>=35$ & 0.49 & 4 & 1 & $\$$ & 119,684 & $\$$ & 109,002 & $\$$ & 228,686 \\
\hline Essential hypertension & 401 & $>=35$ & 0.08 & 7 & 10 & $\$$ & 94,496 & $\$$ & 158,972 & $\$$ & 253,469 \\
\hline Cerebrovascular disease & $430-438$ & $>=35$ & 0.07 & 110 & 109 & $\$$ & $2,265,830$ & & $2,135,263$ & $\$$ & $4,401,093$ \\
\hline Respiratory tuberculosis & 011-012 & $>=35$ & 0.25 & 0 & 0 & $\$$ & 3,657 & $\$$ & 6,312 & $\$$ & 9,969 \\
\hline Diabetes mellitus & 250 & $>=35$ & 0.05 & 24 & 15 & $\$$ & 474,304 & $\$$ & 288,274 & $\$$ & 762,578 \\
\hline Pneumonia and influenza & 480-487 & $>=35$ & 0.05 & 103 & 109 & $\$$ & $1,936,020$ & & $1,985,425$ & $\$$ & $3,921,444$ \\
\hline Diseases of the esophagus, stomach, duodenum & $530-537 *$ & $>=35$ & 0.1 & 17 & 24 & $\$$ & 399,583 & $\$$ & 541,127 & $\$$ & 940,709 \\
\hline Chronic hepatitis & 571.4 & $>=35$ & 0.5 & 1 & 1 & $\$$ & 9,769 & $\$$ & 3,751 & $\$$ & 13,520 \\
\hline Cirrhosis without mention of alcohol & 571.5 & $>=35$ & 0.5 & 10 & 5 & $\$$ & 123,106 & $\$$ & 95,761 & $\$$ & 218,866 \\
\hline Other chronic nonalcoholic liver damage/disease & 571.8 & $>=35$ & 0.5 & 0 & 1 & $\$$ & - & $\$$ & 44,501 & $\$$ & 44,501 \\
\hline Portal hypertension & 572.3 & $>=35$ & 0.5 & 1 & 0 & $\$$ & 44,127 & $\$$ & - & $\$$ & 44,127 \\
\hline Acute pancreatitis & 577 & $>=35$ & 0.42 & 210 & 139 & $\$$ & $5,537,993$ & & $2,716,143$ & $\$$ & $8,254,136$ \\
\hline Chronic pancreatitis & 577.1 & $>=35$ & 0.6 & 18 & 10 & $\$$ & 349,639 & & 145,554 & $\$$ & 495,193 \\
\hline Injuries and poisonings (see Appendix B1) & & & & & & & $25,097,405$ & & $-8,082,231$ & & $53,179,636$ \\
\hline $\begin{array}{c}\text { TOTAL } \\
\end{array}$ & & & & 2,791 & 1,398 & & $55,306,903$ & & $14,486,655$ & & $999,793,558$ \\
\hline
\end{tabular}

Due to rounding, totals may not equal $100 \%$. 
Table 6.1b

Drug-related hospital inpatient direct costs, Maine 2010

\begin{tabular}{|c|c|c|c|c|c|c|c|c|}
\hline \multirow[b]{2}{*}{ Diagnosis or condition } & \multirow[b]{2}{*}{ ICD-9 code } & \multirow[b]{2}{*}{$\begin{array}{c}\text { Age } \\
\text { range }\end{array}$} & \multirow[b]{2}{*}{ DAF } & \multicolumn{2}{|c|}{$\begin{array}{l}\text { Est. number of drug- } \\
\text { related discharges }\end{array}$} & \multicolumn{3}{|c|}{ Estimated drug-related inpatient charges } \\
\hline & & & & Males & Females & Male & Female & Total \\
\hline Drug mental disorders \& psychoses & 292 & All & 1 & 655 & 526 & $\$ 4,354,798$ & $\$ 3,417,555$ & $\$ 7,772,353$ \\
\hline Drug dependence & 304 & All & 1 & 217 & 162 & $\$ 1,763,578$ & $\$ 1,351,869$ & $\$ 3,115,447$ \\
\hline Nondependent abuse of drugs & $305.2-.9$ & All & 1 & 29 & 10 & $\$ 254,725$ & $\$ 99,766$ & $\$ 354,491$ \\
\hline Polyneuropathy due to drugs & 357.6 & All & 1 & 1 & 0 & $\$ 22,719$ & $\$ \quad-$ & $\$ 22,719$ \\
\hline $\begin{array}{l}\text { Drug dependence complicating pregnancy, } \\
\text { childbirth, or puerperium }\end{array}$ & 648.3 & All & 1 & 0 & 60 & $\$$ & $\$ 33,762$ & $\$ 333,762$ \\
\hline $\begin{array}{l}\text { Drugs affecting fetus or newborn via placenta or } \\
\text { breast }\end{array}$ & $\begin{array}{l}\text { 760.72, .73, } \\
.75\end{array}$ & All & 1 & 1 & 0 & $\$ 21,752$ & $\$$ & $\$ 21,752$ \\
\hline Drug withdrawal syndrome in newborn & 779.5 & All & 1 & 10 & 6 & $\$ 301,079$ & $\$ 113,582$ & $\$ 414,661$ \\
\hline Fetal damage due to drugs & 655.5 & All & 1 & 0 & 1 & $\$ \quad-$ & $\$ 3,614$ & $\$ 3,614$ \\
\hline Poisoning by opiates and related narcotics & 965 & All & 1 & 88 & 128 & $\$ 1,385,769$ & $\$ 1,779,549$ & $\$ 3,165,318$ \\
\hline Poisoning by sedatives and hypnotics & 967 & All & 1 & 13 & 16 & $\$ 190,896$ & $\$ 154,555$ & $\$ 345,451$ \\
\hline $\begin{array}{l}\text { Poisoning by central nervous system muscle tone } \\
\text { depressants }\end{array}$ & 968 & All & 1 & 0 & 0 & $\$$ & $\$$ & $\$$ \\
\hline Poisoning by psychotropic agents & 969 & All & 1 & 127 & 199 & $\$ 1,625,010$ & $\$ 2,441,492$ & $\$ 4,066,502$ \\
\hline Poisoning by central nervous system Stimulants & 970 & All & 1 & 9 & 6 & $\$ 163,925$ & $\$ 24,476$ & $\$ 188,401$ \\
\hline TOTAL & & & & 1150 & 1114 & $\$ 10,084,482$ & $\$ 9,720,220$ & $\$ 19,804,471$ \\
\hline
\end{tabular}


Table 6.2a

Estimated alcohol-related hospital outpatient charges, Maine, 2010

\begin{tabular}{|c|c|c|c|c|c|c|c|c|}
\hline \multirow[b]{2}{*}{ Diagnosis or condition } & \multirow[b]{2}{*}{ ICD-9 code } & \multirow[b]{2}{*}{ Age range } & \multirow[b]{2}{*}{ AAF } & \multicolumn{2}{|c|}{$\begin{array}{l}\text { Est. number of } \\
\text { alcohol related visits }\end{array}$} & \multicolumn{3}{|c|}{ Estimated alcohol related outpatient charges } \\
\hline & & & & Males & Females & Male & Female & Total \\
\hline $\begin{array}{l}\text { Alcohol induced mental disorders \& } \\
\text { psychoses }\end{array}$ & 291 & All & 1 & 485 & 172 & $\$ 741,999$ & $\$ 243,717$ & $\$ 985,715$ \\
\hline Alcohol dependence syndrome & 303 & All & 1 & 7861 & 4304 & $\$ 6,110,719$ & $\$ 2,892,095$ & $\$ 9,002,815$ \\
\hline Non-dependent abuse of alcohol & 305 & All & 1 & 2627 & 1369 & $\$ 2,766,308$ & $\$ 1,449,714$ & $\$ 4,216,022$ \\
\hline Alcoholic polyneuropathy & 357.5 & All & 1 & 7 & 9 & $\$ 1,463$ & $\$ 4,690$ & $\$ 6,154$ \\
\hline Alcoholic cardiomyopathy & 425.5 & All & 1 & 23 & 3 & $\$ 13,256$ & $\$ 989$ & $\$ 14,245$ \\
\hline Alcoholic gastritis & 535.3 & All & 1 & 9 & 3 & $\$ 12,714$ & $\$ 3,639$ & $\$ 16,353$ \\
\hline Alcoholic fatty liver & 571 & All & 1 & 25 & 3 & $\$ 11,688$ & $\$ 3,976$ & $\$ 15,664$ \\
\hline Acute alcoholic hepatitis & 571.1 & All & 1 & 62 & 52 & $\$ 35,618$ & $\$ 29,376$ & $\$ 64,994$ \\
\hline Alcoholic cirrhosis of the liver & 571.2 & All & 1 & 267 & 151 & $\$ 146,122$ & $\$ 99,663$ & $\$ 245,785$ \\
\hline Alcoholic liver damage, unspecified & 571.3 & All & 1 & 41 & 22 & $\$ 25,991$ & $\$ 10,371$ & $\$ 36,362$ \\
\hline Excessive blood levels of alcohol & 790.3 & All & 1 & 4 & 2 & $\$ 1,093$ & $\$ 2,633$ & $\$ 3,726$ \\
\hline Toxic effect of alcohol & 980 & All & 1 & 2837 & 4463 & $\$ 2,067,653$ & $\$ 2,432,257$ & $\$ 4,499,910$ \\
\hline Accidental poisoning by alcohol & E860.0-.1 & All & 1 & 5 & 1 & $\$ 13,714$ & $\$ 1,770$ & $\$ 15,484$ \\
\hline $\begin{array}{l}\text { Cancer of the lip, tongue, oral cavity, } \\
\text { pharynx }\end{array}$ & $140-149$ & $>=35$ & 0.5 & 781 & 318 & $\$ 2,057,675$ & $\$ 759,786$ & $\$ 2,817,461$ \\
\hline Cancer of the esophagus & 150 & $>=35$ & 0.75 & 1098 & 244 & $\$ 2,421,961$ & $\$ 402,243$ & $\$ 2,824,204$ \\
\hline Cancer of the stomach & 151 & $>=35$ & 0.2 & 104 & 46 & $\$ 290,610$ & $\$ 79,694$ & $\$ 370,304$ \\
\hline $\begin{array}{l}\text { Cancer of the liver and intrahepatic bile } \\
\text { ducts }\end{array}$ & $155.0-155.2$ & $>=35$ & 0.15 & 64 & 39 & $\$ 218,889$ & $\$ 66,162$ & $\$ 285,051$ \\
\hline Cancer of the larynx & 161 & $>=35$ & 0.49 & 259 & 67 & $\$ 1,024,094$ & $\$ 134,827$ & $\$ 1,158,921$ \\
\hline Essential hypertension & 401 & $>=35$ & 0.08 & 5070 & 6385 & $\$ 1,269,645$ & $\$ 1,573,849$ & $\$ 2,843,494$ \\
\hline Cerebrovascular disease & $430-438$ & $>=35$ & 0.07 & 742 & 761 & $\$ 661,688$ & $\$ 681,708$ & $\$ 1,343,396$ \\
\hline Respiratory tuberculosis & 011-012 & $>=35$ & 0.25 & 6 & 6 & $\$ 3,075$ & $\$ 1,641$ & $\$ 4,716$ \\
\hline Diabetes mellitus & 250 & $>=35$ & 0.05 & 3875 & 4088 & $\$ 1,159,829$ & $\$ 1,145,406$ & $\$ 2,305,235$ \\
\hline Pneumonia and influenza & $480-487$ & $>=35$ & 0.05 & 375 & 460 & $\$ 302,869$ & $\$ 320,930$ & $\$ 623,799$ \\
\hline $\begin{array}{l}\text { Diseases of the esophagus, stomach, } \\
\text { duodenum }\end{array}$ & $\begin{array}{l}530-537 \\
\text { exc } 535.3\end{array}$ & $>=35$ & 0.1 & 1239 & 1756 & $\$ 1,491,191$ & $\$ 1,959,198$ & $\$ 3,450,389$ \\
\hline Chronic hepatitis & 571.4 & $>=35$ & 0.5 & 43 & 146 & $\$ 29,380$ & $\$ 53,163$ & $\$ 82,542$ \\
\hline Cirrhosis without mention of alcohol & 571.5 & $>=35$ & 0.5 & 678 & 451 & $\$ 382,561$ & $\$ 287,207$ & $\$ 669,768$ \\
\hline
\end{tabular}




\begin{tabular}{|c|c|c|c|c|c|c|c|c|}
\hline $\begin{array}{l}\text { Other chronic nonalcoholic liver damage } \\
\text { \& disease }\end{array}$ & 571.8 & $>=35$ & 0.5 & 277 & 333 & $\$ 265,018$ & $\$ 199,717$ & $\$ 464,735$ \\
\hline $\begin{array}{l}\text { Unspecified chronic liver disease w/o } \\
\text { mention of alcohol }\end{array}$ & 571.9 & $>=35$ & 0.5 & 37 & 51 & $\$ 12,411$ & $\$ 16,487$ & $\$ 28,897$ \\
\hline Portal hypertension & 572.3 & $>=35$ & 0.5 & 22 & 15 & $\$ 35,881$ & $\$ 17,093$ & $\$ 52,974$ \\
\hline Acute pancreatitis & 577 & $>=35$ & 0.42 & 337 & 299 & $\$ 467,210$ & $\$ 399,631$ & $\$ 866,841$ \\
\hline Chronic pancreatitis & 577.1 & $>=35$ & 0.6 & 225 & 163 & $\$ 358,438$ & $\$ 235,220$ & $\$ 593,658$ \\
\hline Injury (see appendix B2) & & & & 23,404 & 23,415 & $\$ 28,900,354$ & $\$ 22,755,260$ & $\$ 51,655,614$ \\
\hline *Total (Alcohol) & & & & 29,482 & 26,179 & \$ 53,301,117 & $\$ 38,264,112$ & $\$ 91,565,229$ \\
\hline
\end{tabular}

Table 6.2b

Estimated drug-related hospital outpatient charges, Maine, 2010

\begin{tabular}{|c|c|c|c|c|c|c|c|c|}
\hline \multirow[b]{2}{*}{ Diagnosis or Condition } & \multirow[b]{2}{*}{ ICD-9 Code } & \multirow[b]{2}{*}{$\begin{array}{l}\text { Age } \\
\text { Range }\end{array}$} & \multirow[b]{2}{*}{ AAF } & \multicolumn{2}{|c|}{$\begin{array}{l}\text { Est. Number of Drug } \\
\text { Related Visits } \\
\end{array}$} & \multicolumn{3}{|c|}{ Estimated Alcohol Related Outpatient Charges } \\
\hline & & & & Males & Females & Male & Female & Total \\
\hline Drug psychoses & 292 & All & 1 & 734 & 722 & $\$ 625,984$ & $\$ 648,422$ & $\$ 625,984$ \\
\hline Drug dependence & 304 & All & 1 & 18237 & 18728 & $\$ 11,586,512$ & $\$ 10,735,846$ & $\$ 11,586,512$ \\
\hline Nondependent abuse of drugs & $305.2-.9$ & All & 1 & 3072 & 3003 & $\$ 1,946,450$ & $\$ 1,842,284$ & $\$ 1,946,450$ \\
\hline Polyneuropathy due to drugs & 357.6 & All & 1 & 2 & 12 & $\$ 326$ & $\$ 7,457$ & $\$ 326$ \\
\hline $\begin{array}{l}\text { Drug dependence complicating } \\
\text { pregnancy, childbirth, or puerperium }\end{array}$ & 648.3 & All & 1 & 0 & 1072 & & $\$ 522,266$ & $\$ 0$ \\
\hline $\begin{array}{l}\text { Drugs affecting fetus or newborn via } \\
\text { placenta or breast }\end{array}$ & $\begin{array}{l}760.72, .73 \\
.75\end{array}$ & All & 1 & 15 & 15 & $\$ 9,003$ & $\$ 12,040$ & $\$ 9,003$ \\
\hline Drug withdrawal syndrome in newborn & 779.5 & All & 1 & 45 & 38 & $\$ 6,068$ & $\$ 5,722$ & $\$ 6,068$ \\
\hline Fetal damage due to drugs & 655.5 & All & 1 & 0 & 316 & & $\$ 253,023$ & $\$ 0$ \\
\hline $\begin{array}{l}\text { Poisoning by opiates and related } \\
\text { narcotics }\end{array}$ & 965 & All & 1 & 228 & 299 & $\$ 421,481$ & $\$ 551,374$ & $\$ 421,481$ \\
\hline Poisoning by sedatives and hypnotics & 967 & All & 1 & 46 & 65 & $\$ 74,920$ & $\$ 147,729$ & $\$ 74,920$ \\
\hline $\begin{array}{l}\text { Poisoning by central nervous system } \\
\text { muscle tone depressants }\end{array}$ & 968 & All & 1 & 3 & 2 & $\$ 2,091$ & $\$ 2,003$ & $\$ 2,091$ \\
\hline Poisoning by psychotropic agents & 969 & All & 1 & 315 & 462 & $\$ 662,017$ & $\$ 884,209$ & $\$ 662,017$ \\
\hline $\begin{array}{l}\text { Poisoning by central nervous system } \\
\text { Stimulants }\end{array}$ & 970 & All & 1 & 28 & 22 & $\$ 40,272$ & $\$ 34,777$ & $\$ 40,272$ \\
\hline$*$ Total (Drug) & & & & 22,725 & 24,756 & $\$ 15,375,123$ & $\$ 15,647,151$ & $\$ 31,022,274$ \\
\hline
\end{tabular}


Table 6.2C

Total estimated alcohol and drug-related hospital inpatient and outpatient charges, Maine, 2010

\begin{tabular}{|c|c|c|c|c|c|c|}
\hline & Male & Female & Cost-Male & Cost-Female & Total & Total Adjusted \\
\hline \multicolumn{7}{|l|}{ Inpatient } \\
\hline Alcohol & 2,791 & 1,398 & $\$ 55,306,903$ & $\$ 44,486,655$ & $\$ 99,793,558$ & $\$ 99,793,558$ \\
\hline Drug & 1,150 & 1,114 & $\$ 10,084,482$ & $\$ 9,720,220$ & $\$ 19,804,471$ & $\$ 19,804,471$ \\
\hline $\begin{array}{c}\text { Adjust for long-term } \\
\text { inpatient }(.213)\end{array}$ & & & & & & $\$ 25,474,380$ \\
\hline Total Inpatient & 3,941 & 2,512 & $\$ 65,391,385$ & $\$ 54,206,875$ & $\$ 119,598,260$ & $145,072,409$ \\
\hline \multicolumn{7}{|l|}{ Outpatient } \\
\hline Alcohol & 29,482 & 26,179 & $\$ 53,301,117$ & $\$ 38,264,112$ & $\$ 91,565,229$ & $\$ 91,565,229$ \\
\hline Drug & 22,725 & 24,756 & $\$ 15,375,123$ & $\$ 15,647,152$ & $\$ 31,022,275$ & $\$ 31,022,275$ \\
\hline Total Outpatient & 52,207 & 50,935 & $\$ 68,676,240$ & $\$ 53,911,264$ & $\$ 122,587,504$ & $\$ 122,587,504$ \\
\hline TOTAL & 56,148 & 53,447 & $\$ 120,120,913$ & $\$ 100,458,657$ & $\$ 242,285,764$ & $\$ 267,659,913$ \\
\hline
\end{tabular}


Table 6.3

Other medical costs due to alcohol, Maine, 2010

\begin{tabular}{lrrr}
\hline \multicolumn{1}{c}{ Cost category } & Total cost & $\begin{array}{c}\text { Attributable } \\
\text { fraction }\end{array}$ & Cost \\
\hline Prescription drugs $^{17}$ & $\$ 1,257,720,222$ & & \\
Nursing home care $^{18}$ & $\$ 750,000,000$ & $1.0 \%$ & $\$ 27,669,845$ \\
& & & \\
\hline TOTAL & $\$ \mathbf{2 , 0 0 7 , 7 2 0 , 2 2 2}$ & & $\mathbf{\$ 3 5 , 1 6 9 , 8 4 5}$ \\
\hline
\end{tabular}

\section{Summary}

Total medical costs associated with drug and alcohol abuse for Maine in 2010 were estimated at \$302.8 million, including the added cost of treating illnesses unrelated to substance abuse among persons with a co-occurring drug or alcohol disorder. Of this amount \$145.1 million represents inpatient hospital care, of which $70 \%$ of the total was related to medical problems and injuries resulting from alcohol use and abuse. Outpatient medical services accounted for \$122.6 million (double what it was in 2005), while alcohol problem-related prescription drugs accounted for \$27.7 million, and nursing home care another \$7.5 million.

\footnotetext{
${ }^{17}$ Kaiser Family Foundation. (2013). Total retail sales for prescription drugs filled at pharmacies, 2011. Available: www.statehealthfacts.org (Accessed February 14, 2013).

${ }^{18}$ Kaiser Family Foundation. (2013). Maine: Distribution of health care expenditures by service (in millions), 2009. Available: www.statehealthfacts.org (Accessed February 14, 2013).
} 


\section{Chapter 7}

\section{Other Related Costs}

In addition to the costs examined in the previous chapters, there are three other drug and alcoholrelated costs that are included in this analysis. These are the substance abuse related costs of: 1) child welfare and the administration of other social welfare programs, 2) fire protection and the destruction caused by fire, and 3) the non-medical costs of motor vehicle accidents. The general methodology used to estimate these costs was similar to that used to estimate other costs. Attributable risk coefficients, used by Rice at al. (1990) and NIDA/NIAAA (1998), were applied to cost data obtained from secondary data sources and used to generate estimates of costs related to drug and alcohol abuse.

\section{The major findings of the analysis were:}

- An estimated \$45.9 million in child welfare costs related to substance abuse was spent in Maine during 2010.

- An estimated \$3.5 million was spent on social welfare administration in Maine during 2010 related to drug and alcohol abuse.

- Alcohol is believed to play a role in a large proportion of fires. In 2010, the estimated cost of these fires in Maine was \$9.5 million.

- The non-medical cost of alcohol-related motor vehicle crashes in Maine in 2010 is estimated at $\$ 53.0$ million.

- The combined cost of all of these cost categories was $\$ 111.9$ million.

\section{Methodology}

Since the methods used to derive the cost estimates vary among the three areas, the methodological description is provided as part of the results sections. 


\section{Results}

\section{Child welfare}

Although there is little documented data on this subject for Maine, a report by the Maine Bureau of Child and Family Services (BCFS, 2003) to the Maine Legislature indicates that 50\% or more of the Bureau's clients in SFY03 needed substance abuse services. This estimate is supported by data from the National Center on Addiction and Substance Abuse at Columbia University (CASA, 1999), which states that in a survey of child welfare professionals, the vast majority felt that "substance abuse causes or contributes to at least half of all cases of child maltreatment." This report goes on to suggest that, based on additional research, an average of $70 \%$ of cases of child abuse and neglect are directly or indirectly associated with substance abuse. Data in the Child Protective Services 2010 report (OCFS, 2010) recognized alcohol and drug misuse of the caretaker or family member was identified 1,943 times as a stress factor during assessments. For this report, with agreement from the Office of Child and Family Services we will use $52.6 \%$ (1,119 cases), which is the exact percentage of substantiated cases of child abuse where alcohol and or drug abuse was identified as one of the multiple risk factors for removing a child. We will continue to use the 2005 methodology that assumes that of the substance-abuse related cases, $67 \%$ were due to alcohol abuse by parents or guardians and 33\% were due to drug abuse, based on NIDA/NIAAA's distribution of social welfare administration costs.

The estimated total cost of protecting Maine's children from abuse and neglect in 2010 was $\$ 87,250.00$ (MDHHS OCFS, 2013). The 2010 expenditures were lower than 2005 due to multiple factors, including increase in attrition, salary freezes, and state government shut down days, etc., rather than a decrease in the need for social services. Applying the above-mentioned proportion $52.6 \%$ to this total, child welfare costs due to substance abuse were $\$ 45.9$ million, with \$30.7 million due to alcohol abuse and \$15.1 million due to drug abuse.

\section{Social Welfare Administration}

Social welfare programs serve individuals with substance abuse problems. Therefore, it is appropriate to include a portion of these expenses as part of the overall costs of substance abuse. Direct welfare payments to clients, however, are considered transfer (redistribution) payments, and thus are not included. 
Drug and alcohol-related administrative costs for social welfare programs are shown in Table 7.1. The first two program categories shown are OASDI and SSI, two federal programs representing Old Age, Survivors and Disability Insurance (Social Security Administration, OASDI, Table 2) and Supplemental Security Income (Social Security Administration, Table SSI7). In December 2010 in Maine, 299,875 persons (22.6\% of the total population, which is $10 \%$ higher than in 2005) were receiving Social Security benefits (185,849 retired workers, 22,473 widows and widowers, 55,525 disabled workers, 11,878 wives and husbands, and 24,150 children). In December 2010, 35,426 persons were receiving Supplemental Security Income (SSI). Of these, 1,988 were aged, 215 were blind, and 33,223 were disabled (SSA, 2010). The next program category represents Temporary Assistance for Needy Families (U.S. Department of Health and Human Services, 2007, TANF, Table C) and the food stamp program, SNAP (U.S. Department of Agriculture, 2007). The final category is veterans' pensions and rehabilitation (U.S. Veterans Administration, Table 22). After applying the relevant attributable fractions, the total estimated cost for all social welfare programs combined is approximately \$3.5 million, \$2.4 million attributed to alcohol and \$1.2 million to drugs.

Table 7.1

Estimated administrative costs of selected social welfare programs attributed to substance abuse, Maine, 2010

\begin{tabular}{|c|c|c|c|c|c|}
\hline \multirow[b]{2}{*}{ Program } & \multirow{2}{*}{$\begin{array}{c}\text { Total } \\
\text { administrative } \\
\text { Costs }\end{array}$} & \multirow{2}{*}{$\begin{array}{c}\text { AAF/DAF } \\
\text { \% [1] }\end{array}$} & \multirow{2}{*}{$\begin{array}{l}\text { Alcohol and } \\
\text { drug admin. } \\
\text { costs } \\
\text { combined }\end{array}$} & \multicolumn{2}{|c|}{ Attributed to: } \\
\hline & & & & $\begin{array}{l}\text { Alcohol } \\
(67 \%) \\
{[1]}\end{array}$ & $\begin{array}{c}\text { Drugs } \\
(33 \%) \\
{[1]}\end{array}$ \\
\hline OASDI [2] & $\$ 94,484,000$ & 1.7 & $\$ 1,606,228$ & $\$ 1,076,173$ & $\$ 530,055$ \\
\hline SSI [3] & $\$ 13,547,943$ & 3.0 & $\$ 406,438$ & $\$ 272,314$ & $\$ 134,125$ \\
\hline TANF [4] & $\$ 2,813,267$ & 5.2 & $\$ 146,290$ & $\$ 98,014$ & $\$ 48,276$ \\
\hline SNAP [5] & $\$ 21,009,743$ & 5.2 & $\$ 1,092,507$ & $\$ 731,979$ & $\$ 360,527$ \\
\hline $\begin{array}{l}\text { Veterans compensation } \\
\text { and pension [6] }\end{array}$ & $\$ 17,042,056$ & 1.7 & $\$ 289,715$ & $\$ 194,109$ & $\$ 95,606$ \\
\hline Total & $\$ 148,897,009$ & & $\$ 3,541,178$ & $\$ 2,372,589$ & $\$ 1,168,589$ \\
\hline \multicolumn{6}{|l|}{ Notes and Sources: } \\
\hline \multicolumn{6}{|c|}{ [1] NIDA/NIAAA, 1998, Table D.3. } \\
\hline \multicolumn{6}{|c|}{ [2] Social Security Administration; Old Age, Survivors and Disability Insurance (OASDI), 2006, Table 5} \\
\hline \multirow{2}{*}{\multicolumn{6}{|c|}{$\begin{array}{l}\text { [3] Social Security Administration; Supplemental Security Income (SSI), 2006,Table 7.B7 } \\
\text { [4] U.S. Dept. of Health and Human Services; Temporary Assistance for Needy Families (TANF), Table B (FY 2005) } \\
\text { [5] U.S. Dept. of Agriculture; Food Stamp Program Annual Benefits (FY 2005) }\end{array}$}} \\
\hline & tamp Program Annual Be & nefits (FY 2005) & & & \\
\hline
\end{tabular}




\section{Fire Destruction}

Alcohol plays a role in economic losses resulting from fire destruction. While the precise extent of this role is unknown, the best available information from an early study (Berry \& Boland, 1973) suggests that approximately $6.1 \%$ of structural fire destruction and $11.2 \%$ of fire protection costs can be associated with alcohol use. Because the total cost of structural damage and fire protection in Maine is not available, these values were determined by using national data and adjusting for inflation and Maine's population size. The source of structural fire damage cost was from the National Fire Protection Association (2012) and the costs of fire protection

were originally from the U. S. Census Bureau (1994) and cited in NIDA/NIAAA (1998). The National Fire Protection Association estimated a cost of $\$ 34.60$ per capita for the Northeast region for structural fire damage (Karter, 2012). Northeast was defined to include Connecticut, Maine, Massachusetts, New Hampshire, New Jersey, New York, Pennsylvania, Rhode Island, and Vermont. The resulting estimated cost of fire destruction related to alcohol abuse is $\$ 9.5$ million.

Table 7.2

Estimated Alcohol-Related Cost of Fire Protection and Property Damage and Destruction Maine, 2010

\begin{tabular}{lccc}
\hline Type of Cost/Loss & $\begin{array}{c}\text { Total } \\
\text { Costs/Losses }\end{array}$ & $\begin{array}{c}\text { Alcohol } \\
\text { Attributable } \\
\text { Fraction [3] }\end{array}$ & $\begin{array}{c}\text { Total } \\
\text { Alcohol-Related } \\
\text { Losses (\$) }\end{array}$ \\
\hline $\begin{array}{l}\text { Fire Protection Costs [1] } \\
\begin{array}{l}\text { Property Damage/Destruction [2] } \\
\text { Residential Structure }\end{array}\end{array}$ & $\$ 61,835,205$ & 0.112 & $\$ 6,925,543$ \\
$\quad$ Other Structure & $\$ 3,031,556$ & 0.061 & $\$ 2,014,925$ \\
\hline Total & & 0.061 & $\$ 513,212$ \\
\hline
\end{tabular}

Notes and Sources:

[1] U. S. Bureau of the Census, 1994; adjusted for Maine population and inflation

[2] National Fire Protection Association, 2011; Fire Loss in the United States During 2010 


\section{Motor Vehicle Crashes (Non-Medical Costs)}

Use or abuse of drugs and alcohol is a significant risk factor for motor vehicle accidents. Costs resulting from alcohol- or drug-related accidents result in premature death, medical care, vehicle damage, and legal and court costs. The costs related to premature death were presented in Chapter 4 and those related to medical care were reported in Chapter 6. This section reports on other motor vehicle accident costs, including legal and court costs, insurance administration, and vehicle damage. The source of the cost data is NIDA/NIAAA (1998, Table 6-17). Data on the percent of alcohol-related fatalities in Maine was provided by the U.S. Department of Transportation, Traffic Safety Facts, 2010.

While drug abuse is known to contribute to some accidents, there is no published, reliable research on the frequency of drug-related accidents. Because of this lack of data, a national cost study (NIDA/NIAAA, 1998) limited the cost estimates to alcohol-related crashes only. The same approach is followed here. National data on the costs of motor vehicle crashes presented in NIDA/NIAAA (1998) were adjusted for inflation and Maine’s population size. Table 7.3 shows the resulting estimates by type of cost for Maine and the percentage attributable to alcohol abuse (Appendix C shows greater detail). In Maine during 2010, there were 161 total motor vehicle fatalities. Thirty-eight (23\% of total) were instances in which a driver had a blood alcohol level of $0.08 \mathrm{~g} / \mathrm{dl}$ or greater. The total non-medical costs of alcohol-related automobile accidents were estimated at \$53.1 million. The most costly accident category was property damage, which accounted for $35.4 \%$ of the total costs, followed by minimum/moderate injury accidents, $27.4 \%$. 
Table 7.3

Estimated Non-Medical Cost of Alcohol-Related Motor Vehicle Crashes, Maine, 2010

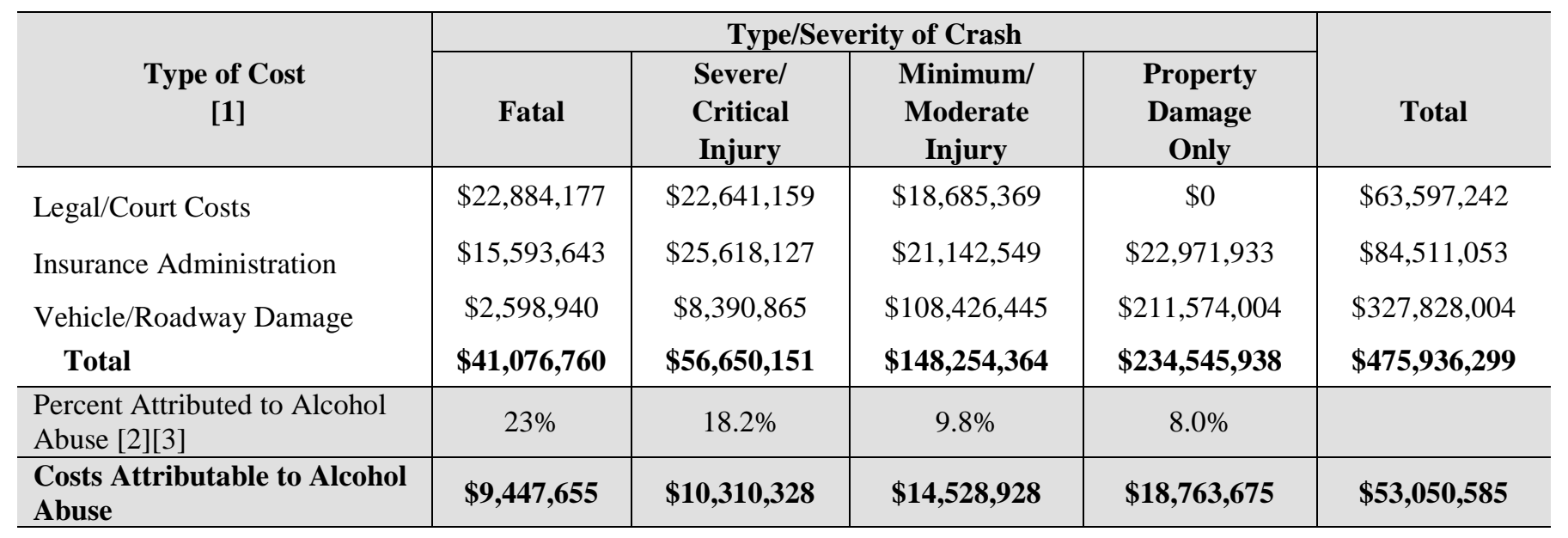

Notes and Sources:

[1] NIDA/NIAAA (1998) (see http://archives.drugabuse.gov/EconomicCosts/Table6_17.html) adjusted for inflation

[2] U.S. Department of Transportation, Traffic Safety Facts 2010, Table 117 - the percentage of fatal crashes involving a driver with a BAC $\geq 0.08 \mathrm{~g} / \mathrm{dl}$

[3] Brucker (2007) Cost Report; NIDA/NIAAA (1998) (see http://archives.drugabuse.gov/EconomicCosts/Table6_17.html). Calculated for BAC $\geq 0.10$ g/dl

(injury and property damage rate is approximately $57.6 \%$ of national rate shown in NIDA/NIAAA report)

\section{Summary}

This chapter presented estimates for selected costs not included in previous chapters. Of the three cost categories examined, social welfare administration (\$49.4 million), fire destruction (\$9.5 million), and non-medical motor vehicle accident costs (\$53.0 million), the motor vehicle crashes were the highest, accounting for $47.4 \%$ of the total cost (\$111.9 million). . 


\section{Chapter 8}

\section{Summary}

The purpose of this report has been to determine in economic terms the cost to society of substance abuse among Maine residents in 2010. We have quantified these costs according to the major categories in which actual costs are expended or opportunities for economic productivity are lost: substance abuse treatment; morbidity; mortality; crime; medical care; and other related costs. Although this type of analysis cannot measure the emotional toll exacted by alcohol and drug abuse, and devalues certain segments of the population (e.g., youth, homemakers and the elderly), it nonetheless provides a valuable comparison between the resources invested in the prevention and treatment of substance abuse, and the costs resulting from these disorders. This report also provides a benchmark for tracking changes in these costs over time; allowing comparisons between the similarly structured 2000 and 2005 cost reports. ${ }^{19}$

\section{Major Findings}

- In 2010, the total estimated cost of substance abuse in Maine was $\$ 1.403$ billion.

- This $\$ 1.403$ billion translates into an annual cost of $\$ 1,057$ for every resident of Maine.

- Substance abuse treatment ( $\$ 47.0$ million) comprised the smallest category of total cost (3.3\%), while mortality ( $\$ 409.6$ million) comprised the largest (29.2\%).

\section{Overview}

The total 2010 economic cost of drug and alcohol abuse in Maine was estimated at $\$ 1.403$ billion (see Table 8 for a breakdown by category). Figure 8.1 graphically compares the 2000, 2005 and 2010 category amounts. The largest single cost category in 2010 was mortality, accounting for an estimated \$409.6 million, followed by crime, \$343.4 million, medical care, \$302.8 million, morbidity \$166.1 million, and other related costs, \$111.9 million. The total cost of \$1.381 billion translates to a per capita cost of $\$ 1,040$ for every Maine resident in 2010. The proportion

\footnotetext{
${ }^{19}$ As we have specified throughout the report, care is needed in making comparisons with previous cost reports. It is important to verify the details of the methodology to verify the same procedures and attributable were used. Although we have utilized the same methods in most sections, there are changes; these are specified in the report.
} 
of the total cost attributed to different categories have not changed dramatically since 2005, but nearly all categories have increased. Shown as percentages of the total cost in 2010 (Figure 8.2), crime and mortality accounted for the largest portions of the total cost.

Table 8

Summary: Estimated Cost of Alcohol and Drug Abuse by Category Maine, 2010

\begin{tabular}{|c|c|c|}
\hline Category & Cost & $\%$ \\
\hline TREATMENT & $\$ 46,975,900$ & $3.3 \%$ \\
\hline MORBIDITY & $\$ 188,637,664$ & $13.4 \%$ \\
\hline MORTALITY & $\$ 409,642,749$ & $29.2 \%$ \\
\hline CRIME & $\$ 343,410,384$ & $24.5 \%$ \\
\hline Law Enforcement & $\$ 119,674,301$ & \\
\hline Police Protection & $\$ 47,655,600$ & \\
\hline Drug Control & $\$ 72,018,701$ & \\
\hline Supply/Demand Reduction (Federal) & $\$ 64,681,757$ & \\
\hline Prevention (State) & $\$ 7,336,944$ & \\
\hline Judicial & $\$ 20,983,081$ & \\
\hline Corrections & $\$ 111,041,604$ & \\
\hline State & $\$ 68,403,301$ & \\
\hline County & $\$ 42,638,303$ & \\
\hline Other & $\$ 91,711,398$ & \\
\hline Productivity Loss Due to Incarceration & $\$ 81,496,528$ & \\
\hline Property Destruction Due to Crime & $\$ 7,232,403$ & \\
\hline Productivity Loss for Victims & $\$ 2,982,467$ & \\
\hline MEDICAL CARE & $\$ 302,829,757$ & $21.6 \%$ \\
\hline Hospital Care & $\$ 267,659,913$ & \\
\hline Inpatient & $\$ 145,072,409$ & \\
\hline Outpatient & $\$ 122,587,504$ & \\
\hline Other Costs & $\$ 35,169,844$ & \\
\hline Prescription Drugs & $\$ 27,669,844$ & \\
\hline Nursing Home & $\$ 7,500,000$ & \\
\hline OTHER & $\$ 111,938,943$ & $8.0 \%$ \\
\hline Social Welfare & $\$ 49,434,678$ & \\
\hline Child Welfare & $\$ 45,893,500$ & \\
\hline Other Welfare (Administration Only) & $\$ 3,541,178$ & \\
\hline Fire Protection and Destruction Due to Fire & $\$ 9,453,680$ & \\
\hline Motor Vehicle Crashes (Non-Medical Costs) & $\$ 53,050,585$ & \\
\hline TOTAL & $\$ 1,403,435,398$ & $100.00 \%$ \\
\hline
\end{tabular}




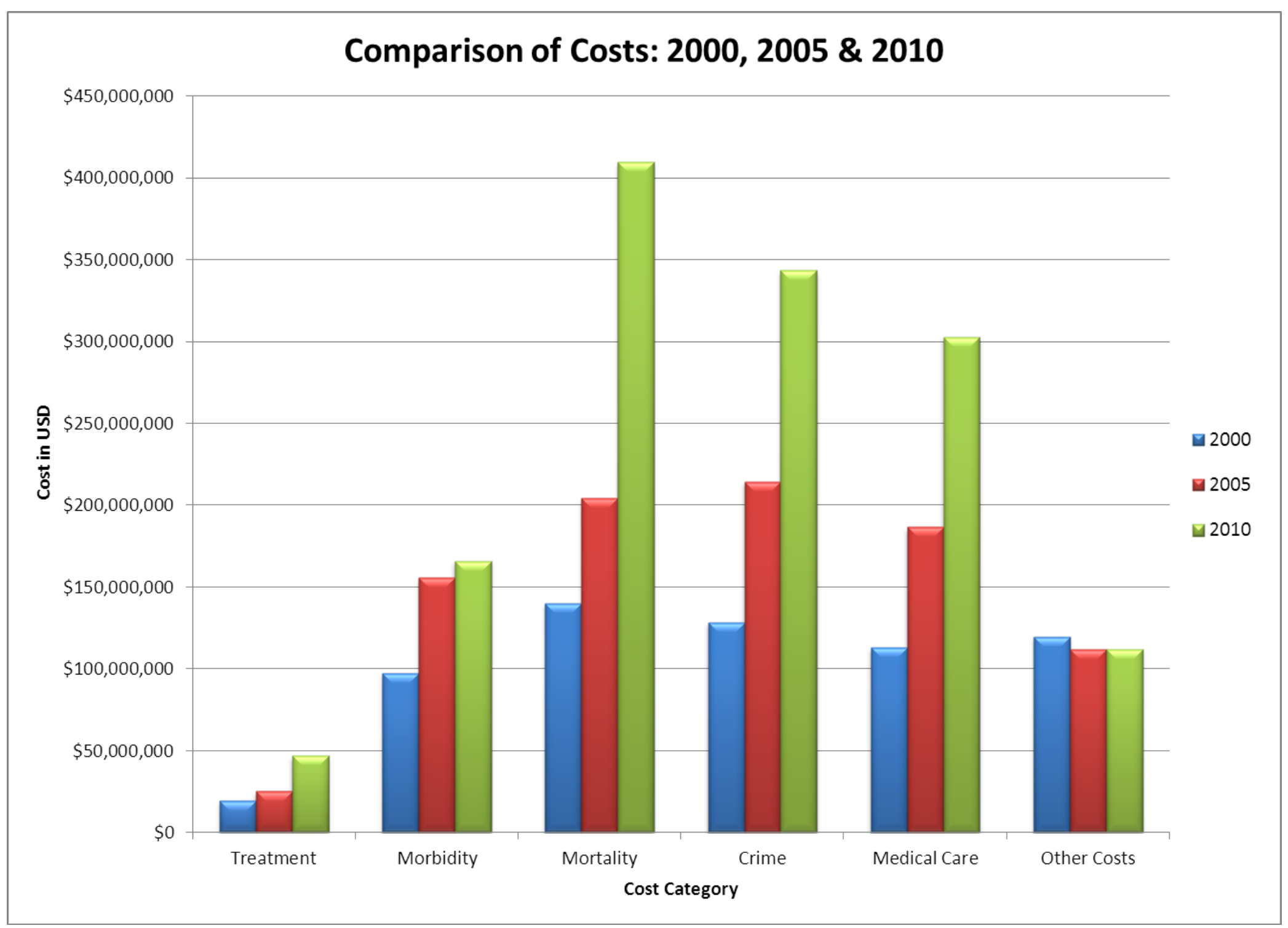

Figure 8.1 


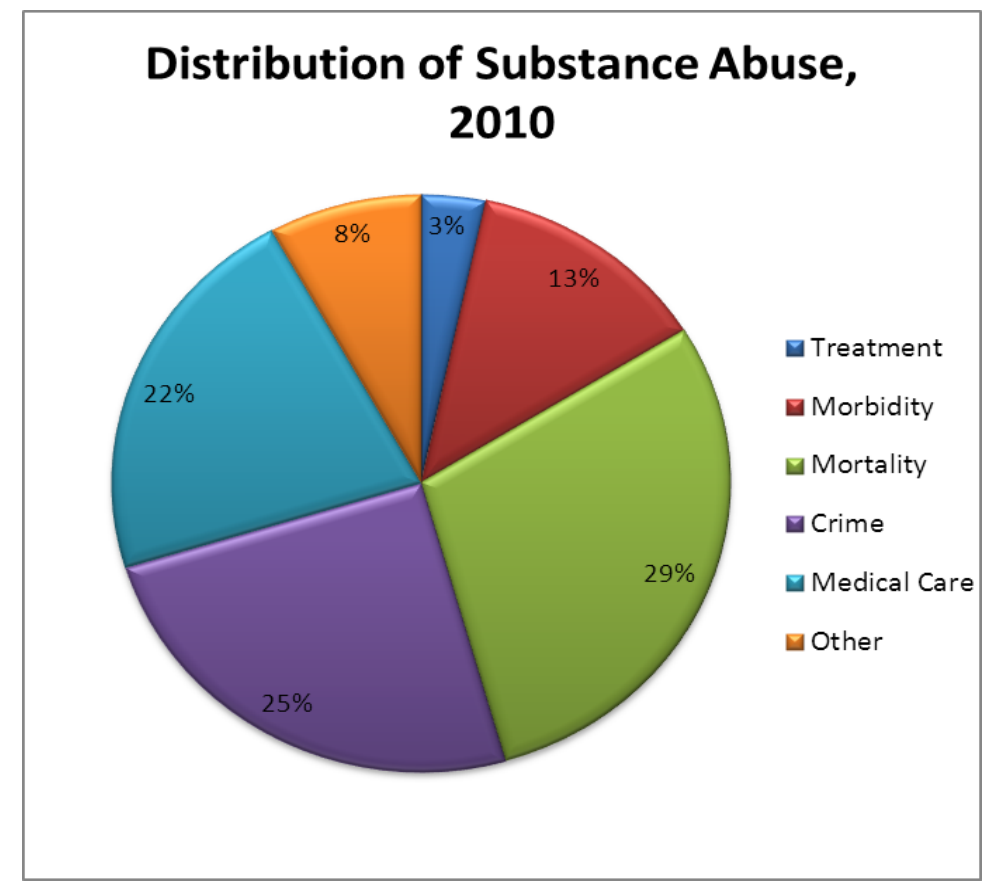

Figure 8.2

\section{Conclusions}

The total estimated cost of substance abuse in Maine in 2010 was $\$ 1.403$ billion, compared to $\$ 898.4$ million in 2005 , an increase of $56.2 \%$. The category comprising the smallest proportion of the total cost (3.3\%) was substance abuse treatment at $\$ 47.0$ million. At \$409.6 million, the category showing the highest estimated cost was mortality (29.2\% of total). This is a change from the 2000 and 2005 reports where crime was the highest cost factor. At least 39\% of total costs of substance use and abuse are due to drugs. Because some of the cost categories, such as motor vehicle crashes, do not measure the impact of drugs, this percent is likely an underestimate.

Although the goal of this report was to document the economic costs associated with drug and alcohol abuse, readers should keep in mind that substance abuse also has serious consequences that affect individuals and their families in ways that cannot be quantified through economic analysis. In 2010, it was estimated that 713 persons in Maine died of causes related to drug or alcohol abuse, resulting in a potential loss of 15,896 years of life, and substantially more people suffered from substance-related illnesses, injuries, and domestic violence. Clearly, the consumption of alcohol and other drugs creates costs that are not only born by the producer or the consumer of the products, but also by society as a whole, including substantial lost economic productivity. 


\section{References}

Bouchery, E., Simon, C., and Harwood, H. (2010, December) Economic costs of excessive alcohol consumption in the United States, 2006. Submitted by The Lewin Group, Inc. for The Centers for Disease Control and Prevention.

Brucker, D. (2007, December). The cost of alcohol and drug abuse in Maine, 2005. Augusta, ME: Division of Data and Research, Office of Substance Abuse, Department of Health and Human Services.

CASAColumbia: National Center on Addiction and Substance Abuse at Columbia University. (1999) No safe haven: Children of substance abusing parents. New York, NY: Author.

Harwood, HJ, Napolitano, DM, Krisianson, P. and Collins, JJ. (1984). The economic costs to society of alcohol and drug abuse and mental illness: 1980. Research Triangle Park, NC: Research Triangle Institute.

Inflation data U.S. (2012). Cumulative inflation calculator. Retrieved from http://inflationdata.com/inflation/Inflation_Rate/InflationCalculator.asp\#results; Accessed multiple times in 2011, 2012)

Karter, M.J. (2012). Fire loss in the United States during 2011. Quincy, MA: National Fire Protection Association. Retrieved from http://www.nfpa.org/assets/files/PDF/OS.fireloss.pdf

Maine Dept. of Corrections. (2012) Sentence counts by offense. For 1/1/2010 - 12/31/2010. Unpublished data. (Ellis King)

Maine Dept. of Health and Human Services, Office of Child and Family Services (2013) Personal communication with Bill Fox, Program Fiscal Coordinator. Unpublished data.

Maine Dept. of Health and Human Services, Office of Data, Research, and Vital Statistics. (2012). Unpublished alcohol and drug related mortality data. Kim Haggan.

Maine Dept. of Public Safety. (2012) Crime in Maine, 2010. Retrieved from http://www.maine.gov/dps/cim/crime_in_maine/2010contents.htm

Maine Health Data Organization. (2013). Inpatient and outpatient data for 2010 completed data run by William Kilbreth and Thomas Seger, February 8, 2013.

Max, W., Rice, D. P., Sung, H., and Michel, M. (2004) Valuing human life: Estimating the $P V L E$, 2000. Retrieved from http://escholarship.org/uc/item/82d0550k

National Institute on Drug Abuse (1998). The Economic costs of drug and alcohol abuse in the United States, 1992. Bethesda, MD: Author. 
Office of National Drug Control Policy (2004). The economic costs of drug abuse in the United States, 1992-2002. Washington, DC: Executive Office of the President (Publication no. 207303) Retrieved from https://www.ncjrs.gov/ondcppubs/publications/pdf/economic_costs.pdf

Office of National Drug Control Policy (2010) National Drug Control Strategy : FY 2011 Budget Summary. Washington, DC: Executive Office of the President Retrieved from: http://www.whitehouse.gov/sites/default/files/ondcp/policy-and-research/fy11budget.pdf

Rice, DP, Kelman, S, Miller, LS, and Dunmeyer, S. (1990). The economic costs of alcohol and drug abuse and mental illness: 1985. Bethesda, MD: National Institute on Drug Abuse

Social Science Research Council. (2010/2011). Life expectancy for females and males living in Maine. Retrieved from http://www.measureofamerica.org/maps/ (accessed on 1/23/2013)

U.S. Social Security Administration. (2010). Social Security Administrative expenses: Administrative expenses as a percentage of total expenditures, 1957-2012. Administrative expenses for 2010: $0.9 \%$ of total, $0.6 \%$ of OASI, $2.3 \%$ of DI Retrieved from http://www.ssa.gov/OACT/STATS/admin.html

U.S. Social Security Administration. (2010). State statistics for December 2010: Maine, Retrieved from http://www.ssa.gov/policy/docs/factsheets/cong_stats/2010/me.html

Substance Abuse and Mental Health Services Administration. (2011) Data from National Survey on Drug Use and Health (NSDUH), with years 2006-2009 aggregated by Art Hughes, Center for Behavioral Health Statistics. Unpublished data.

Substance Abuse and Mental Health Services Administration. (2013) Maine estimates based on National Survey of Drug Use and Health 2010, 2011 data run through R-DAS by Art Hughes, Center for Behavioral Health Statistics. Unpublished data.

U.S. Dept. of Agriculture (2011). Food and nutrition service. Supplemental nutrition assistance program state activity report- federal fiscal year 2010. Table 1: Supplemental nutrition and assistance program participation and issuance. Retrieved from http://www.fns.usda.gov/snap/qc/pdfs/2010_state_activity.pdf

US Census Bureau. (2010). 2010 Census Interactive Population Search. Retrieved from http://2010.census.gov/2010census/popmap/ipmtext.php?fl=23

US Census Bureau. (2007). M1901-M1902. Median earnings for male and female full-time year round workers (in 2005 inflation-adjusted dollars). 2005 American Community Survey.

US Census Bureau, Population Division. (2007). Table 1: Annual estimates of the population by five year age groups and sex: April 1, 2000 to July 1, 2006. Retrieved from http://www.census.gov/popest/national/asrh/NC-EST2006/NC-EST2006-01.xls 
US Dept. of Health and Human Services. (2011). TANF financial data. FY 2010. Table C.2.a: State maintenance of effort (MOE) expenditures in the TANF program in FY 2010. Retrieved from http://www.acf.hhs.gov/sites/default/files/ofa/2010_tanf_data_with_states.pdf

US Dept. of Justice. (2012). Sourcebook of criminal justice statistics. Retrieved from http://www.albany.edu/sourcebook/pdf/t100112012.pdf

U.S. Dept. of Justice Programs, Bureau of Justice Statistics (11/27/2012) Conversation with Todd Minton, Research Analyst. regarding data from the 2011 U.S. DOJ, Bureau of Justice Statistics survey.

US Dept. of Labor, Bureau of Labor Statistics. (2010). Archived Consumer Price Index detailed report tables. Retrieved from www.bls.gov/cpi/cpi_dr.htm\#2000.

US Dept. of Labor, Bureau of Labor Statistics. (2012). Maine median earnings in 2005. Retrieved from http://www.bls.gov/oes/current/oes_me.htm\#b00-0000.

US Dept. of Labor, Bureau of Labor Statistics. (2010). Employment status of civilian noninstitutional population. Retrieved from http://www.bls.gov/lau/table14full10.pdf

US Dept. of Transportation, National Highway Traffic Safety Administration. (2012). Traffic safety facts 2010. Retrieved from http://www-nrd.nhtsa.dot.gov/Pubs/811659.pdf

US Dept. of Transportation, National Highway Traffic Safety Administration. (February 2012). Traffic Safety Facts 2010: Research Note. Retrieved from http://www.nrd.nhtsa.dot.gov/Pubs/811552.pdf

US Dept. of Veterans Affairs. (2010). Veteran benefits administrations. Annual benefits report, 2010. Retrieved from http://www.vba.va.gov/REPORTS/abr/

US Office of National Drug Control Policy. (2011). ADAM II 2010 Annual Report. Retrieved from http://www.whitehouse.gov/sites/default/files/ondcp/policy-and-research/adam2010.pdf

Webster, BH and Bishaw, A. (2006). Income, earnings, and poverty: Data from the 2005 American Community Survey (ACS-02). Washington DC: U.S. Government Printing Office.

Wickizer, TM. (2007). The economic costs of drug and alcohol abuse in Washington State, 2005. Seattle, WA: University of Washington. 
Appendix A

Calculation of Estimated Morbidity Costs

\begin{tabular}{|c|c|c|c|c|c|c|c|c|c|c|c|c|c|c|c|}
\hline & A & B & C & D & $\mathbf{E}$ & $\mathbf{F}$ & G & $\mathbf{H}$ & $\mathbf{I}$ & $\mathbf{J}$ & $\mathbf{K}$ & L [1] & M [2] & $\mathbf{N}[3]$ & $O[4]$ \\
\hline & \multicolumn{3}{|c|}{ Employed } & \multicolumn{3}{|c|}{ Not in labor force } & $\begin{array}{c}\text { Median } \\
\text { earnings }\end{array}$ & \multicolumn{2}{|c|}{ Housekeeping } & \multicolumn{3}{|c|}{ Impairment rates } & \multicolumn{3}{|c|}{ Morbidity costs } \\
\hline & $\begin{array}{l}\text { Alcohol } \\
\text { disorder }\end{array}$ & $\begin{array}{c}\text { Drug } \\
\text { disorder }\end{array}$ & $\begin{array}{c}\text { Alcohol } \\
\text { and/or } \\
\text { drug } \\
\text { disorder }\end{array}$ & $\begin{array}{l}\text { Alcohol } \\
\text { disorder }\end{array}$ & $\begin{array}{l}\text { Drug } \\
\text { disorder }\end{array}$ & $\begin{array}{c}\text { Alcohol } \\
\text { and/or } \\
\text { drug } \\
\text { disorder }\end{array}$ & & $\begin{array}{c}\text { In } \\
\text { labor } \\
\text { force }\end{array}$ & $\begin{array}{l}\text { Not in } \\
\text { labor } \\
\text { force }\end{array}$ & Alcohol & Drugs & $\begin{array}{c}\text { Alcohol } \\
\text { and/or } \\
\text { drug } \\
\text { disorder }\end{array}$ & Alcohol & Drugs & $\begin{array}{c}\text { Alcohol } \\
\text { and/or } \\
\text { drug } \\
\text { disorder }\end{array}$ \\
\hline & $\mathbf{N}$ & $\mathbf{N}$ & $\mathbf{N}$ & $\mathbf{N}$ & $\mathbf{N}$ & $\mathbf{N}$ & $\$$ & $\$$ & $\$$ & & & & $\$$ & $\$$ & $\$$ \\
\hline \multicolumn{16}{|l|}{ Male } \\
\hline $18-24$ & 8067 & 3796 & 10002 & 5029 & 2367 & 6235 & 26,127 & 3,910 & 8,103 & 0.0140 & 0.0110 & 0.0161 & $\$ 3,962,819$ & $\$ 1,465,203$ & $\$ 5,650,332$ \\
\hline $25-44$ & 19115 & 6279 & 22044 & 2266 & 744 & 2614 & 40,641 & 4,918 & 9,186 & 0.0425 & 0.0545 & 0.0517 & $\$ 37,896,220$ & $\$ 15,963,014$ & $\$ 53,163,875$ \\
\hline $45-64$ & 13393 & 3270 & 16664 & 3911 & 955 & 4866 & 46,447 & 5,326 & 9,604 & 0.0740 & 0.0780 & 0.0740 & $\$ 54,090,820$ & $\$ 13,920,623$ & $\$ 67,301,397$ \\
\hline $65+$ & $*$ & $*$ & $*$ & $*$ & $*$ & $*$ & 16,227 & 3,973 & 7,550 & 0.0930 & 0.0730 & * & $\begin{array}{r}* \\
\$ 95,949,859\end{array}$ & $\$ 31,348,840$ & $\$ 126,115,604$ \\
\hline \multicolumn{16}{|l|}{ Female } \\
\hline $18-24$ & 5078 & 4131 & 7654 & 2535 & 2062 & 3822 & 19,882 & 12,367 & 20,474 & 0.0080 & 0.0020 & 0.0065 & $\$ 1,725,296$ & $\$ 350,876$ & $\$ 2,113,056$ \\
\hline $25-44$ & 8629 & 3627 & 11757 & 2406 & 1011 & 3277 & 26,796 & 14,658 & 22,718 & 0.0735 & 0.0145 & 0.0674 & $\$ 30,308,906$ & $\$ 2,513,163$ & $\$ 37,866,773$ \\
\hline $45-64$ & 2403 & 751 & 2703 & 948 & 296 & 1067 & 34,835 & 12,938 & 21,092 & 0.1530 & 0.0455 & * & $\$ 20,623,441$ & $\$ 1,916,494$ & $\$ 22,542,231$ \\
\hline \multirow[t]{2}{*}{$65+$} & $*$ & $*$ & * & $*$ & $*$ & $*$ & 16,257 & 6,142 & 10,068 & 0.1870 & 0.0730 & $*$ & & & \\
\hline & & & & & & & & & & & & & $\$ 52,657,644$ & $\$ 4,780,533$ & $\$ 62,522,060$ \\
\hline Total & & & & & & & & & & & & & $\$ 148,607,503$ & $\$ 36,129,373$ & $\$ 188,637,664$ \\
\hline
\end{tabular}

Sources: US Census Bureau, 2010; Baird, Lanctot and Clough, 2004; Rice et al., 1990

Notes:

$[1] \mathrm{L}=\left[(\mathrm{A} / \mathrm{C})^{*} \mathrm{~J}\right]+\left[(\mathrm{B} / \mathrm{C})^{*} \mathrm{~K}\right]$

[2] $M=[(A *(G+H)+(D * I)] * J$

[3] $\mathrm{N}=[(\mathrm{B} *(\mathrm{G}+\mathrm{H})+(\mathrm{E} * \mathrm{I})] * \mathrm{~K}$

$[4] \mathrm{O}=\left[\left(\mathrm{C} *(\mathrm{G}+\mathrm{H})+\left(\mathrm{F}^{*} \mathrm{I}\right)\right] * \mathrm{~L}\right.$ 
Appendix B.1

ICD-9 Codes and Alcohol Attributable Fractions for Alcohol-Related Injuries and Associated Hospital Inpatient Charges, Maine, 2010

\begin{tabular}{|c|c|c|c|c|c|c|c|c|c|c|c|}
\hline & & \multirow{2}{*}{\multicolumn{2}{|c|}{$\begin{array}{c}\text { Total } \\
\text { Discharges [1] }\end{array}$}} & \multirow{2}{*}{\multicolumn{2}{|c|}{$\begin{array}{c}\text { Total } \\
\text { Charges [1] }\end{array}$}} & \multirow{2}{*}{\multicolumn{3}{|c|}{$\begin{array}{l}\text { Alcohol-Related } \\
\text { Discharges }\end{array}$}} & \multirow{2}{*}{\multicolumn{3}{|c|}{ Alcohol-Related Charges }} \\
\hline & & & & & & & & & & & \\
\hline & & Males & Females & Males & Females & [2] & Males & Females & Males & Females & Total \\
\hline 800-968 & Injuries/poisonings (excl. 965.0, 967, 968.0) & 3058 & 3785 & $\$ 93,755,006$ & $\$ 94,066,536$ & 0.10 & 305.8 & 378.5 & $\$ 9,375,501$ & $\$ 9,406,654$ & $\$ 18,782,154$ \\
\hline 980-995 & Injuries/poisonings (excl. 980.0) & 90 & 96 & $\$ 1,852,943$ & $\$ 1,489,444$ & 0.10 & 9 & 9.6 & $\$ 185,294$ & $\$ 148,944$ & $\$ 334,239$ \\
\hline E810-E825 & Motor vehicle traffic/nontraffic accidents [3] & 184 & 111 & $\$ 14,217,323$ & $\$ 6,960,197$ & 0.23 & 40.48 & 24.42 & $\$ 3,127,811$ & $\$ 1,531,243$ & $\$ 4,659,054$ \\
\hline E826-E829 & Pedal cycle/other road vehicle accidents & 7 & 7 & $\$ 271,721$ & $\$ 374,827$ & 0.20 & 1.4 & 1.4 & $\$ 54,344$ & $\$ 74,965$ & $\$ 129,310$ \\
\hline E830-E838 & Water transport accidents & 1 & 2 & $\$ 42,780$ & $\$ 456,576$ & 0.20 & 0.2 & 0.4 & $\$ 8,556$ & $\$ 91,315$ & $\$ 99,871$ \\
\hline E840-E945 & Air/space transport accidents & 2 & 0 & $\$ 333,394$ & $\$-$ & 0.16 & 0.32 & 0 & $\$ 53,343$ & $\$ 0$ & $\$ 53,343$ \\
\hline E880-E888 & Accidental falls & 933 & 1757 & $\$ 29,230,309$ & $\$ 44,495,236$ & 0.35 & 326.55 & 614.95 & $\$ 10,230,608$ & $\$ 15,573,333$ & $\$ 25,803,941$ \\
\hline E890-E899 & Accidents caused by fire/flames & 11 & 2 & $\$ 602,701$ & $\$ 23,349$ & 0.45 & 4.95 & 0.9 & $\$ 271,215$ & $\$ 10,507$ & $\$ 281,723$ \\
\hline E910 & Accidental drowning/submersions & 108 & 72 & $\$ 3,662,268$ & $\$ 1,877,406$ & 0.38 & 27 & 18 & $\$ 915,567$ & $\$ 469,352$ & $\$ 1,384,919$ \\
\hline E950-E959 & Suicide/self inflicted injury & 2 & 0 & $\$ 16,414$ & - & 0.28 & 0.76 & 0 & $\$ 6,237$ & $\$ 0$ & $\$ 6,237$ \\
\hline E960-E969 & Homicide & 99 & 133 & $\$ 1,677,599$ & $\$ 2,328,149$ & 0.46 & 27.72 & 37.24 & $\$ 469,728$ & $\$ 651,882$ & $\$ 1,121,609$ \\
\hline & Other injuries/adverse effects & 28 & 15 & $\$ 867,827$ & $\$ 269,644$ & 0.25 & 12.88 & 6.9 & $\$ 399,200$ & $\$ 124,036$ & $\$ 523,237$ \\
\hline $\begin{array}{l}\text { E901,E911 } \\
\text { E917,E918 } \\
\text { E919,E920 } \\
\text { E922,E980 }\end{array}$ & & & & & & & & & & & \\
\hline Total & & 4,523 & 5,980 & $\$ 146,530,285$ & $\$ 152,341,364$ & & 757 & 1,092 & $\$ 25,097,405$ & $\$ 28,082,231$ & $\$ 53,179,636$ \\
\hline
\end{tabular}

Notes and Source:

[1] Maine Health Data Organization, 2010

[2] NIDA/NIAAA, 1998

[3] AAF is the proportion of fatal crashes in Maine involving a driver with a BAC $\geq 0.08 \mathrm{~g} / \mathrm{dl}$ (U.S. Department of Transportation, 2012). 


\section{APPENDIX B.2}

ICD-9 Codes and Alcohol Attributable Fractions for Alcohol-Related Injuries And Associated Hospital Outpatient Charges, Maine, 2010

\begin{tabular}{|c|c|c|c|c|c|c|c|c|c|c|c|}
\hline & & \multirow{2}{*}{\multicolumn{2}{|c|}{$\begin{array}{c}\text { Total } \\
\text { Outpatient Visits [1] }\end{array}$}} & \multirow{2}{*}{\multicolumn{2}{|c|}{$\begin{array}{c}\text { Total } \\
\text { Charges }[1]\end{array}$}} & \multirow{3}{*}{$\begin{array}{l}\text { AAF } \\
{[2]}\end{array}$} & \multirow{2}{*}{\multicolumn{2}{|c|}{$\begin{array}{c}\text { Alcohol-Related } \\
\text { Visits }\end{array}$}} & \multirow{2}{*}{\multicolumn{3}{|c|}{$\begin{array}{c}\text { Alcohol-Related } \\
\text { Charges }\end{array}$}} \\
\hline & & & & & & & & & & & \\
\hline & & Males & Females & Males & Females & & Males & Females & Males & Females & Total \\
\hline $800-968$ & Injuries/poisonings (excl. 965.0, 967, 968.0) & 105,622 & 97,221 & $\$ 78,041,608$ & $\$ 63,915,965$ & 0.10 & 10,562 & 9,722 & $\$ 7,804,161$ & $\$ 6,391,596$ & $\$ 14,195,757$ \\
\hline $980-995$ & Injuries/poisonings (excl. 980.0) & 3,949 & 4,572 & $\$ 1,770,086$ & $\$ 1,778,704$ & 0.10 & 395 & 457 & $\$ 177,009$ & $\$ 177,870$ & $\$ 354,879$ \\
\hline E810-E825 & Motor vehicle traffic/nontraffic accidents [3] & 746 & 1,102 & $\$ 796,804$ & $\$ 885,015$ & 0.22 & 172 & 253 & $\$ 183,265$ & $\$ 203,553$ & $\$ 386,818$ \\
\hline E826-E829 & Pedal cycle/other road vehicle accidents & 62 & 48 & $\$ 38,620$ & $\$ 28,563$ & 0.20 & 12 & 10 & $\$ 7,724$ & $\$ 5,713$ & $\$ 13,437$ \\
\hline E830-E838 & Water transport accidents & 14 & 6 & $\$ 12,643$ & $\$ 2,677$ & 0.20 & 3 & 1 & $\$ 2,529$ & $\$ 535$ & $\$ 3,064$ \\
\hline E840-E845 & Air/space transport accidents & 1 & 2 & $\$ 1,097$ & $\$ 3,878$ & 0.16 & 0 & 0 & $\$ 176$ & $\$ 620$ & $\$ 796$ \\
\hline E880-E888 & Accidental falls & 2,222 & 3,308 & $\$ 2,220,061$ & $\$ 2,889,997$ & 0.35 & 778 & 1,158 & $\$ 777,021$ & $\$ 1,011,499$ & $\$ 1,788,520$ \\
\hline E890-E899 & Accidents caused by fire/flames & 49 & 30 & $\$ 35,175$ & $\$ 17,796$ & 0.45 & 22 & 14 & $\$ 15,829$ & $\$ 8,008$ & $\$ 23,837$ \\
\hline E910 & Accidental drowning/submersions & 4 & 2 & $\$ 2,261$ & $\$ 5,154$ & 0.38 & 2 & 1 & $\$ 859$ & $\$ 1,959$ & $\$ 2,818$ \\
\hline E950-E959 & Suicide/self inflicted injury & 275 & 454 & $\$ 337,518$ & $\$ 524,937$ & 0.28 & 77 & 127 & $\$ 94,505$ & $\$ 146,982$ & $\$ 241,487$ \\
\hline \multirow[t]{2}{*}{ E960-E969 } & Homicide & 154 & 306 & $\$ 138,632$ & $\$ 223,388$ & 0.46 & 71 & 141 & $\$ 63,771$ & $\$ 102,758$ & $\$ 166,529$ \\
\hline & Other injuries/adverse effects & 1,070 & 852 & $\$ 704,230$ & $\$ 559,460$ & 0.25 & 268 & 213 & $\$ 176,058$ & $\$ 139,865$ & $\$ 315,923$ \\
\hline \multicolumn{12}{|l|}{$\begin{array}{l}\text { E901,E911 } \\
\text { E917,E918 } \\
\text { E919,E920 } \\
\text { E922,E980 }\end{array}$} \\
\hline Total & & 150,843 & 149,844 & $\$ 168,484,020$ & $\$ 137,854,841$ & & 23,404 & 23,415 & $\$ 28,900,354$ & $\$ 22,755,261$ & $\$ 51,655,615$ \\
\hline
\end{tabular}

Sources:
[1] Maine Health Data Organization, 2007
[2] NIDA/NIAAA, 1998
[3] AAF is the proportion of fatal crashes in Maine involving a driver with a BAC $\geq 0.10 \mathrm{~g} / \mathrm{dl}$ (U.S. Department of Transportation, 2005). 
APPENDIX C

Calculation of Estimated Costs of Alcohol-Related Motor Vehicle Crashes, Maine, 2010

\begin{tabular}{|c|c|c|c|c|c|c|c|c|c|c|c|c|}
\hline \multirow{4}{*}{ Type of Costs } & \multicolumn{9}{|c|}{ Type/Severity of Crash } & \multirow{2}{*}{\multicolumn{3}{|c|}{ Property Damage Only }} \\
\hline & \multicolumn{3}{|c|}{ Fatal } & \multicolumn{3}{|c|}{ Severe/Critical Injury } & \multicolumn{3}{|c|}{ Minimum/Moderate Injury } & & & \\
\hline & U.S. 1992 & $\begin{array}{l}\text { U.S. } 2010 \\
\text { Est. }\end{array}$ & Maine & U.S. 1992 & $\begin{array}{l}\text { U.S. } 2010 \\
\text { Est. }\end{array}$ & Maine & U.S. 1992 & $\begin{array}{l}\text { U.S. } 2010 \\
\text { Est. }\end{array}$ & Maine & U.S. 1992 & $\begin{array}{l}\text { U.S. } 2010 \\
\text { Est. }\end{array}$ & Maine \\
\hline & [1] & [2] & [4] & [1] & [2] & [4] & [1] & [2] & [4] & [1] & [2] & [4] \\
\hline Legal/Court Costs (million) & $3,390.0$ & $5,318.9$ & 22.8 & $3,354.0$ & $5,262.4$ & 22.6 & $2,768.0$ & $4,343.0$ & 18.7 & & -- & -- \\
\hline per capita cost [3] & & $\$ 17.23$ & & & $\$ 17.04$ & & & $\$ 14.07$ & & & & \\
\hline Insurance Administration (million) & $2,310.0$ & $3,624.3$ & 15.6 & $3,795.0$ & $5,954.3$ & 25.6 & $3,132.0$ & $4,914.1$ & 21.1 & $3,403.0$ & $5,339.3$ & 22.9 \\
\hline per capita cost [3] & & $\$ 11.74$ & & & $\$ 19.29$ & & & $\$ 15.92$ & & & $\$ 17.29$ & \\
\hline Vehicle and Roadway Damage (million) & 385.0 & 604.0 & 2.6 & $1,243.0$ & $1,950.2$ & 8.4 & $16,062.0$ & $25,201.3$ & 108.4 & $31,342.0$ & $49,175.6$ & 211.6 \\
\hline per capita cost [3] & & $\$ 1.96$ & & & $\$ 6.32$ & & & $\$ 81.62$ & & & $\$ 159.27$ & \\
\hline Total & & & $\$ 41.1$ & & & $\$ 56.6$ & & & $\$ 148.2$ & & & $\$ 234.5$ \\
\hline
\end{tabular}

\begin{tabular}{lcccc}
\hline \multicolumn{2}{l}{ Proportion of Costs due to Alcohol: } & Severe & Moderate & \\
& Fatalities & $\begin{array}{c}\text { Injury } \\
\text { Injury }\end{array}$ & Property \\
\hline U.S. 1992 [1] & $39.7 \%$ & $31.5 \%$ & $17.0 \%$ & $13.9 \%$ \\
Maine, 2005 [5] & $23 \%$ & $18.2 \%$ & $9.8 \%$ & $8.0 \%$ \\
& actual & est. & est. & est. \\
\hline
\end{tabular}

Notes and Sources:

[1] NIDA/NIAAA (1998), Table 6.17 (p.6-28)

[2] 1992 U.S. data adjusted for inflation using the Consumer Price Index rate of 56.9\% over the 13-year period

[3] 2010 U.S. estimate divided by the 2010 U.S. population: $296,507,061$

[4] 2010 U.S. per capita cost multiplied by the 2010 Maine population: 1,328,361

[5] The proportion of fatalities due to alcohol is the percent of fatal crashes in Maine involving a driver with a BAC $\geq 0.08 \mathrm{~g} / \mathrm{dl}$ (U.S. DOT, 2010);

the proportion of less serious crashes due to alcohol is estimated using the same Maine to US proportion as for fatalities, $57.9 \%$. 


\section{Appendix D \\ Data Sources}

Chapter 2: Maine Department of Health and Human Services, Office of Substance Abuse and Mental Health Services

Chapter 3 United States, Department of Health and Human Services, Substance Abuse and Mental Health Services Administration - National Survey on Drug Use or Health;

U. S. Census Bureau;

U. S. Department of Labor

Chapter 4: Maine Department of Health and Human Services, Office of Data, Research and Vital Statistics, 2010 (Retrieved 2012/2013) Produced by Kim Haggan, Health Planner. Maine Office of Chief Medical Examiner, 2010, Produced by Marcella Sorg, University of Maine

Chapter 5: Maine Department of Public Safety; U.S. Department of Justice, Todd Minton; State of Maine Department of Corrections, Ellis King; Cumberland County Corrections Office, Wendy Clark.

Chapter 6: Maine Health Data Organization, William Kilbreth

Chapter 7: Maine Office of Child and Family Services, Mandy Milligan and Robert Blanchard; U. S. Social Security Administration; U. S. Department of Health and Human Services; U. S. Department of Agriculture; National Fire Protection Administration; U. S. Department of Transportation. 


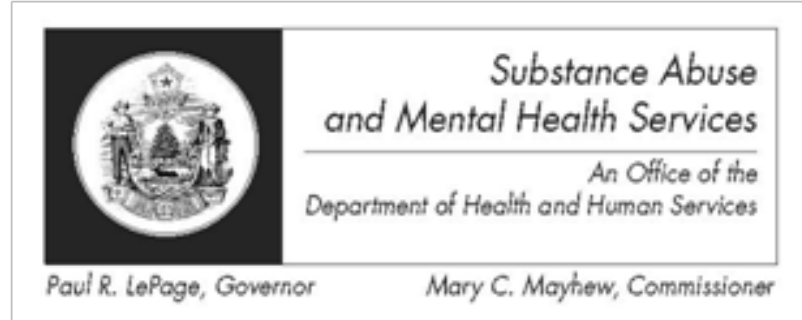

The Department of Health and Human Services does not discriminate on the basis of disability, race, color, creed, gender, sexual orientation, age or national origin in admission or access to or operations of its programs, services, or activities, or its hiring or employment practices.

This notice is provided as required by Title II of the Americans with Disabilities Act of 1990 and in accordance with the Civil Rights Act of 1964 as amended, Section 504 of the Rehabilitation

Act of 1973 as amended, the Age Discrimination Act of 1975, Title IX of the Education Amendments of 1972 and the Maine Human Rights Act.

Questions, concerns, complaints or requests for additional information regarding the ADA may be forwarded to DHHS ADA Compliance/EEO Coordinator, SHS \#11, Augusta, ME 04333;

(207) 287-4289 (V) or (207) 28703488 (V), TTY: 800-606-0215. Individuals who need auxiliary aids or services for effective communication in programs and services of DHHS are invited to make their needs and preferences known to the ADA Compliance/EEO Coordinator.

This information is available in alternate formats upon request. 